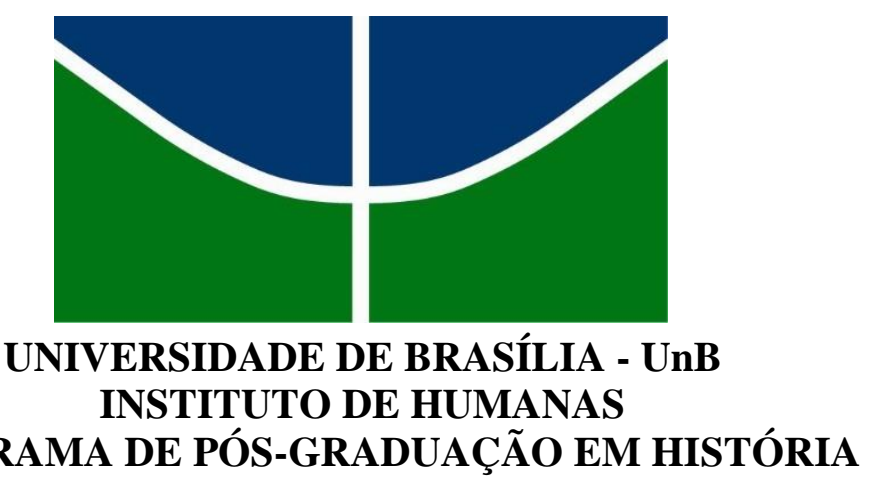

PROGRAMA DE PÓS-GRADUAÇÃO EM HISTÓRIA

DÉBORA JACINTHO DE FARIA

\title{
CRISE DE 1929 \\ CONVERGÊNCIAS E DIVERGÊNCIAS ENTRE O PARTIDO DEMOCRATA E O PARTIDO REPUBLICANO NOS ESTADOS UNIDOS
}


DÉBORA JACINTHO DE FARIA

CRISE DE 1929

CONVERGÊNCIAS E DIVERGÊNCIAS ENTRE O PARTIDO

DEMOCRATA E O PARTIDO REPUBLICANO NOS ESTADOS

UNIDOS

Dissertação apresentada ao Programa de PósGraduação em História - Área de Concentração: Sociedade, cultura e política. Linha de pesquisa: Política, Instituições $e$ Relações de poder da Universidade de Brasília para a obtenção do título de Mestra em História.

Orientador: Virgílio Caixeta Arraes 


\section{FOLHA DE APROVAÇÃO}

Dissertação de Mestrado de autoria de Débora Jacintho de Faria, intitulada "Crise de 1929: Convergências e Divergências entre o Partido Democrata e o Partido Republicano nos Estados Unidos", apresentado como parte dos requisitos necessários à obtenção do grau de Mestra em História no Programa de Pós-Graduação em História da Universidade de Brasília, em 27 de julho de 2016, defendida e aprovada pela Banca Examinadora:

Professor Doutor Virgílio Caixeta Arraes

Orientador

Programa de Pós-Graduação em História da Universidade de Brasília PPGHIS-UnB

Professor Doutor Carlos Eduardo Vidigal

Programa de Pós-Graduação em História da Universidade de Brasília PPGHIS-UnB

Professor Doutor Carlos Augusto Mello Machado Instituto de Ciência Política da Universidade de Brasília IPOL-UnB 
Ao meu avô, Antônio de Pádua Conrado Jacintho (in memoriam). 


\section{AGRADECIMENTOS}

Uma das minhas maiores alegrias foi receber o resultado da aprovação em primeiro lugar no Mestrado em História da UnB, em 2014. Muitas pessoas foram importantes nesse caminho percorrido. Primeiramente, gostaria de agradecer ao professor Virgílio Arraes, por aceitar me orientar nesta dissertação, por todo o auxílio, paciência e conselhos.

Ao Iago, melhor pessoa e melhor migo sempre. Obrigada por todo o suporte e apoio todos os dias, por acreditar em mim e por todo o incentivo que você me dá. Obrigada por ser o melhor companheiro, pelos abraços, pelas noites viradas, pelos cafés, enfim, por me ajudar de todas as formas a chegar até aqui. Um agradecimento especial pela formatação linda dessa dissertação, pela revisão e por todo o auxílio que você me deu durante as etapas dessa escrita.

Aos meus pais, Rubinho e Adriana, por sempre terem me incentivado a estudar e a conquistar meus objetivos. Em especial, obrigada por me proporcionarem realizar minha formação em Brasília, na UnB. Ao meu irmão, Gabriel, futuro acadêmico. À minha tia Elzinha, por ter sido a primeira pessoa a me apresentar a UnB e a me mostrar a vida acadêmica. À minha avó Bernadete, por ser esse exemplo de pessoa. Obrigada enfim a toda a minha família, que sempre torceu pelo meu sucesso.

Obrigada aos meus amigos de orientação, Ana Letícia, Júlia e Fer por compartilharem sofrimentos, mas também risos; pela companhia indispensável nas aulas e nos estudos. Aos demais colegas e professores do PPGHIS-UnB, pelas diversas trocas de conhecimento. Ao Jorge e ao Rodolfo, da secretaria, pela constante dedicação. Ao professor Henrique, pela ajuda concedida a qualquer momento na pós.

Aos professores Vidigal e Sato, pelas valiosas contribuições da qualificação. Ao professor Carlos Machado, pelos enriquecedores conhecimentos na disciplina de Partidos Políticos. Ao professor Doratioto que, através da monografia de América 3, fez brotar a primeira semente dessa pesquisa.

Ao Thiago, por ser quase meu coorientador e por todas as ideias que surgiram na madrugada. À Gabi, essa miga maravilhosa, pelas conversas, coxinhas e buzzfeeds. Ao Duds, por ser um amigo sempre presente e por todos os conselhos. À Silvia e à Gi, amigas de infância e de vida. Ao Toca, pelos vários helps quando precisei. Aos demais amigos e amigas que em diversos momentos passaram pela minha vida e deixaram algum tipo de contribuição.

Ao CNPq, pelo apoio financeiro.

Sem todos vocês eu não teria chegado aqui, então meu muito obrigada. 
"Wit beyond measure is man's greatest treasure." 


\section{RESUMO}

Referência: FARIA, Débora Jacintho de. Crise de 1929: Convergências e divergências entre o Partido Democrata e o Partido Republicano nos Estados Unidos. 2016. 93 f. Dissertação (Mestrado) - Curso de História, Programa de Pós-Graduação em História, Universidade de Brasília, Brasília, 2016.

O objetivo desse trabalho de pesquisa é investigar as convergências e divergências entre o Partido Democrata e o Partido Republicano nos períodos anterior e posterior à Crise de 1929, com recorte temporal de 1912 a 1936. Para tal estudo, serão analisadas as Plataformas Partidárias, de forma a compreender os principais aspectos de seus programas no tocante à política econômica. De modo a uma melhor elucidação do assunto, será feita uma revisão conceitual acerca de 'partido político' e 'crise'. Ademais, partindo da teoria de longa duração Braudel (1969), faz-se necessário estudar alguns momentos relevantes anteriores ao recorte temporal indicado: a formação do Partido Republicano (década de 1850) e a crise de 1873. Considerando a importância das estruturas para a construção da narrativa, tais períodos se mostram relevantes ao entendimento das agremiações e seu comportamento nos eventos que serão estudados. Por fim, as análises serão pensadas a partir dos ciclos da política norteamericana, conceito apresentado por Schlesinger Jr. (1992).

Palavras-chave: Crise de 1929, Partidos Políticos, Partido Democrata, Partido Republicano, Crise, Ciclos. 


\begin{abstract}
The objective of this research is to investigate the similarities and differences between the Democratic Party and the Republican Party in the periods before and after the crisis of 1929, which the time frame is 1912 to 1936 . For this study, the party platforms will be analyzed in order to understand the main aspects of their programs with regard to economic policy. In order to elucidate the matter, a conceptual review will be made about 'political party' and 'crisis'. Moreover, based on the long-term theory Braudel (1969), it is necessary to study some relevant moments before the time frame indicated: the formation of the Republican Party (1850) and the crisis 1873. Considering the importance of the structures for construction of the narrative, such periods are shown relevant to the understanding of the parties and their behavior in the events that will be studied. Finally, the analysis will be designed from the cycles of American politics, concept presented by Schlesinger Jr. (1992).
\end{abstract}

Keywords: 1929 Crisis, Political Party, Democratic Party, Republican Party, Crisis, Cycles. 


\section{LISTA DE TABELAS}

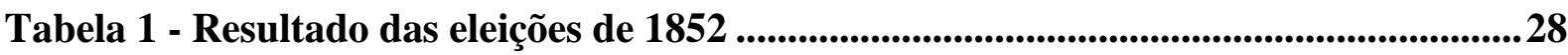

Tabela 2 - Resultado das eleições de 1856 .................................................................................32

Tabela 3 - Resultado das eleições de 1860 ......................................................................35

Tabela 4 - Resultado das eleições de 1876 .................................................................................38

Tabela 5 - Resultado das eleições de 1912 .........................................................................46

Tabela 6 - Resultado das eleições de 1916 ......................................................................49

Tabela 7 - Resultado das eleições de 1920 .................................................................................55

Tabela 8 - Resultado das eleições de 1924 .....................................................................................58

Tabela 9 - Resultado das eleições de 1928 ............................................................................65

Tabela 10 - Resultado das eleições de 1932 ....................................................................... 71

Tabela 11 - Resultado das eleições de 1936 ............................................................................... 76 


\section{SUMÁRIO}

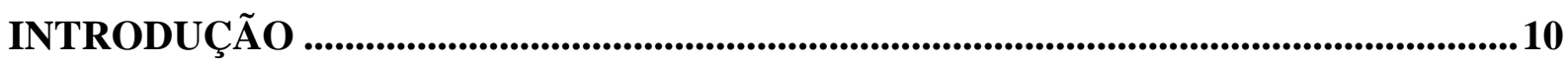

CAPÍTULO 1 ......................................................................................................................................14

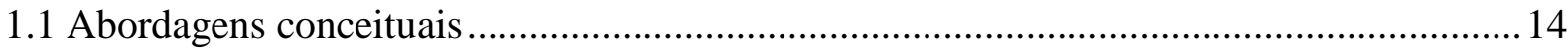

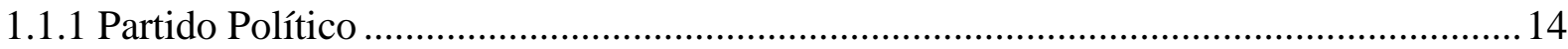

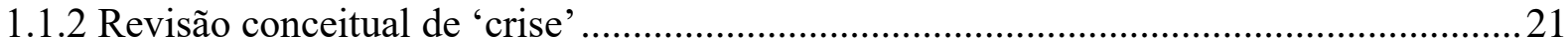

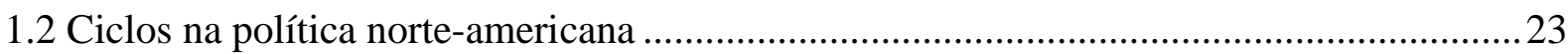

1.3 A formação do Partido Republicano e a consolidação definitiva do bipartidarismo nos

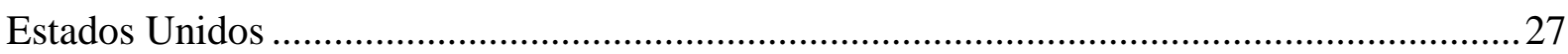

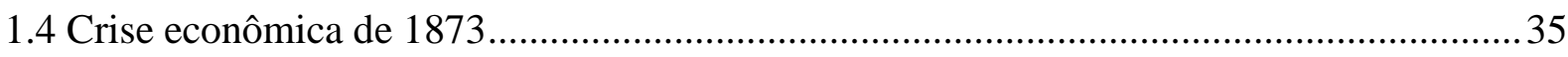

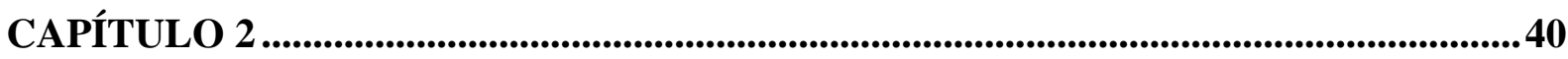

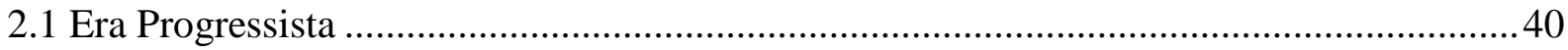

2.1.1 As eleições de $1912 \mathrm{e}$ as transformações no sistema eleitoral .......................................... 40

2.1.2 1916: segunda interrupção democrata ....................................................................... 47

2.2 Década de 1920 - Euforia econômica ........................................................................... 49

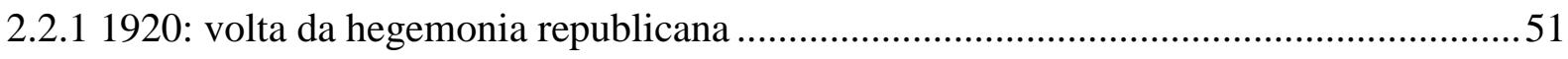

2.2.2 1924: "The business of America is business" ..............................................................54

2.2.3 Perspectivas da década de 1920 ................................................................................58

CAPÍTULO 3 ...................................................................................................................661

$3.1 \mathrm{O}$ melhor momento do capitalismo norte-americano …………………………………......61

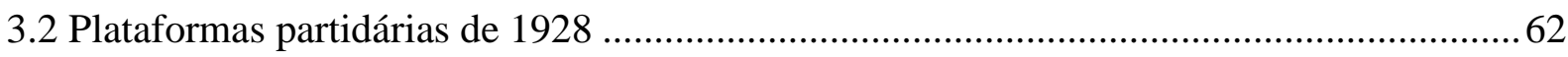

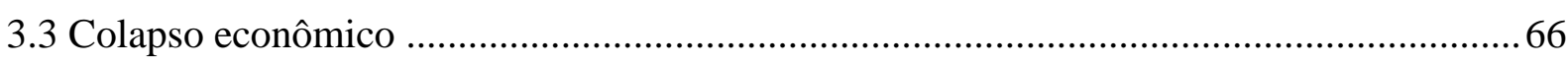

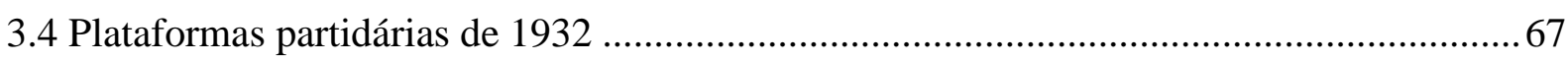

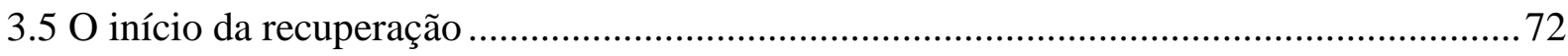

3.6 Plataformas partidárias de 1936 ................................................................................

CONSIDERAÇÕES FINAIS....................................................................................................78

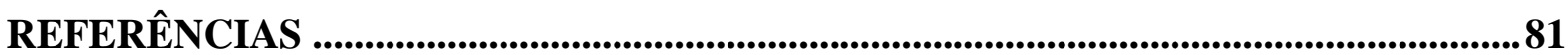




\section{INTRODUÇÃO}

A proposta desta pesquisa é analisar os percursos traçados pelo Partido Democrata e pelo Partido Republicano nos períodos que permeiam a Crise de 1929, com estudo de suas tendências ideológicas, através das posturas demonstradas nas plataformas partidárias. $\mathrm{O}$ objetivo é fazer um comparativo das políticas econômicas apresentadas nos programas, assim como uma verificação das prioridades de agenda das duas principais agremiações. Pretende-se verificar também mudanças de paradigmas e como estes foram afetados com a eclosão da Grande Depressão.

Partindo da teoria sobre longa duração de Braudel (1969), que aborda a escrita da história a partir da longa duração, com análise estrutural dos contextos ${ }^{1}$, pretende-se fazer uma breve reflexão sobre o comportamento dos partidos em períodos anteriores à crise, tais como o momento de formação do Partido Republicano (década de 1850) e a crise econômica de 1873. A pesquisa se concentrará no recorte temporal de 1912 a 1936, mas levando em conta os referidos contextos anteriores para que a análise fique completa.

Almeja-se inserir o presente trabalho na perspectiva da nova história política proposta por Rémond (2003). De acordo com o autor, 'o político' não se define por objetos e recortes pré-estabelecidos, mas sim pela "referência ao poder: [...] a política é a atividade que se relaciona com a conquista, o exercício, a prática do poder, assim os partidos são políticos porque têm como finalidade, e seus membros como motivação, chegar ao poder" (RÉMOND, 2003, p.444).

De acordo com Ranney e Willmore (1956), os partidos, nos Estados Unidos, desempenham um papel crítico na determinação do caráter do sistema político. Além disso, é uma das mais importantes estruturas institucionais, tendo não somente importância política, mas também social e cultural. A base das duas principais agremiações norte-americanas é mais pragmática do que ideológica e o seu domínio majoritário no cenário eleitoral está ligado à estrutura do sistema político do país, com a construção de bases nacionais que exigem alto nível de gerenciamento e financiamento (TOTA, 2008).

No início da República, não havia menções a partidos políticos na Constituição. Porém, logo se percebeu que estes intermediários facilitavam o trabalho do governante através do contato com a opinião pública e no planejamento das políticas públicas. As primeiras

\footnotetext{
${ }^{1}$ Braudel (1969, capítulo 3) disserta sobre a alteração do tempo histórico tradicional, e que as conjunturas e ciclos demandam medidas mais amplas de tempo. Assim, ao estudar crises estruturais, deve-se levar em conta a longa duração, e não apenas pensar no tempo curto.
} 
agremiações surgiram a partir de discordâncias a respeito de políticas domésticas e externas, surgindo assim em 1792 o Partido Federalista, com Alexander Hamilton e John Adams, e o Partido Republicano ${ }^{2}$, com Thomas Jefferson e James Madison. Com estruturas rudimentares no início, os partidos assumem uma caracterização com alto nível de organização entre o final do século XVIII e início do século XIX, quando o sistema partidário se consolida de fato e é legitimada a ideia de oposição política.

O Partido Democrata foi fundado em 1828 e o Partido Republicano, em 1854. Os dois se tornaram os principais atores do sistema político desde então, tendo se consolidado o bipartidarismo de forma definitiva. Sartori (1982) afirma que a alternância no poder é a característica mais marcante da mecânica desse sistema e pondera que o sistema partidário norte-americano pode ser classificado dessa forma uma vez que terceiras vias não afetam, em longo prazo e em nível nacional, o revezamento no poder dos dois partidos principais. Tota (2008) concorda com a tese de Sartori e afirma que poucas as vezes grupos minoritários chegaram perto de vitória. Sendo assim, a partir da segunda metade do século XIX, o monopólio dos dois grandes nunca foi comprometido. Duverger (1980) analisa o bipartidarismo como um fenômeno especificamente anglo-saxão, e afirma que o sistema bipartidário dos Estados Unidos nunca foi seriamente ameaçado, uma vez que as tentativas de terceiros partido falharam ou apenas engendraram pequenas agremiações locais e efêmeras.

O sistema bipartidário tem bastante força nos Estados Unidos devido às particularidades do seu sistema eleitoral, além de uma cultura política amplamente baseada na dualidade. Antes das eleições gerais, a definição dos candidatos de cada partido é realizada por eleições primárias ou por convenções estaduais (a partir do início do século XX) ${ }^{3}$. Nas eleições gerais, o presidente e o vice-presidente não são eleitos pelo voto direto, mas sim pelo Colégio Eleitoral. O processo de escolha dos eleitores do Colégio Eleitoral varia de estado para estado, mas em geral os partidos políticos indicam candidatos nas convenções partidárias estaduais ou por voto em seu comitê central.

\footnotetext{
${ }^{2}$ Hoje é denominado Democrata-Republicano, para ser diferenciado do Partido Republicano fundado em 1860. ${ }^{3}$ As primárias são realizadas com voto secreto, podendo ser fechadas ou abertas. Nas primárias fechadas, o eleitor somente pode votar em um candidato que pertença ao mesmo partido, e nas abertas, o eleitor pode votar em um candidato de qualquer partido. Nas convenções (caucuses), os membros dos partidos se dividem em grupos de acordo com o candidato que apoiam, e cada grupo faz discursos para tentar convencer os eleitores sobre seus candidatos. Disponível em: 〈http://www.usa.gov/election〉. Acesso em: 03 abr. 2016.
} 
Cada um dos estados tem direito a um número de delegados no Colégio Eleitoral correspondente aos seus representantes no Congresso (soma do número dos deputados e senadores). ${ }^{4}$

Os partidos americanos estão organizados nas esferas federal, estadual e local. Nos anos eleitorais, cada partido organiza uma Convenção Nacional para a nomeação dos candidatos a presidente e a vice-presidente e lançam uma plataforma política. Tal documento contém os princípios, objetivos e estratégias que guiarão a campanha presidencial. Os componentes da plataforma são chamados de planks, que correspondem às posturas da sigla sobre determinados tópicos da agenda nacional. Dessa forma, são essenciais para se perceber a proposta e prioridades de cada grupo.

Percebe-se uma evolução da estrutura das plataformas partidárias ao longo do tempo. No século XIX, eram simplificadas, curtas e desprovidas de divisão em assuntos. Começaram a ser aperfeiçoadas a partir do final do século XIX e início do século XX, ficando mais longas e detalhadas. Os planks passam a ser cada vez mais específicos, auxiliando a percepção das prioridades em cada campanha eleitoral. Constata-se o padrão de abordagem nas plataformas de ambos os partidos, especialmente do século XX: uma retomada das políticas adotadas no mandato anterior (seja na forma de crítica ou aprovação) e a apresentação das propostas. A análise desse tipo de documento é importante, então, tanto para compreender a visão dos partidos sobre acontecimentos e políticas adotadas (estando na posição de situação ou oposição) quanto o que se pretende em vias de melhorias ou soluções para as questões em pauta.

Os efeitos da crise que irrompeu nos Estados Unidos em 1929 perduraram fortemente por toda a década de 1930. A crise foi a mais profunda do século XX, e influenciou a política não só dos Estados Unidos, mas do mundo todo. Na Europa, percebeu-se a ascensão da extrema direita em boa parte do continente, tendo por destaque o caso da Alemanha, e a consolidação da extrema esquerda, na URSS (que não sofreu com a depressão, por estar isolada). Assim, seu estudo torna-se essencial para a compreensão da dinâmica econômica não só dos Estados Unidos, mas de todo o mundo durante o decorrer do século XX.

No primeiro capítulo, serão abordadas análises conceituais acerca de partidos políticos e crise. Será feita uma revisão da literatura sobre esses assuntos, para melhor compreender como tais conceitos podem se inserir no contexto dos Estados Unidos no recorte temporal almejado.

\footnotetext{
${ }^{4}$ As informações sobre o sistema eleitoral dos Estados Unidos estão disponíveis em: <http://photos.state.gov/libraries/amgov/30145/publications-english/USA_Elections_InBrief.pdf>; <http://iipdigital.usembassy.gov/st/portuguese/article/2012/03/201203232662.html\#ixzz3ekKFRXIE>; <http://www.usa.gov/election>; < http://www.archives.gov/federal-register/electoral-college/faq.html>. Acesso em: 03 abr. 2016.
} 
Ademais, também no capítulo será feita uma breve abordagem da formação do Partido Republicano, com os assuntos que permeavam a política norte-americana na década de 1850 , analisando divergências e convergências entre a nova sigla e os democratas. Por fim, será discutida a crise de 1873, para perceber o tratamento dos partidos na recessão econômica de grandes proporções que antecipa a Crise de 1929.

No segundo capítulo, é construído o posicionamento dos dois partidos no período anterior à Grande Depressão, aprofundando-se especialmente nos assuntos de cunho econômico. Serão analisadas as plataformas dos anos eleitorais entre 1912 e 1924, sendo que nesses dois anos das extremidades também será feito o estudo do programa do Partido Progressista, além das duas agremiações hegemônicas. Serão abordados o movimento progressista, passando pela administração de Woodrow Wilson até chegar na Era Republicana da década de 1920.

Por fim, o terceiro capítulo será dedicado ao estudo dos governos de Herbert Hoover e Franklin Roosevelt, com enfoque nas plataformas partidárias de 1928, 1932 e 1936, com análise de suas estruturas, da perspectiva econômica e do comportamento e tratamento perante a Crise de 1929. Dessa forma, será possível compreender se houve alterações nos paradigmas dos programas. 


\section{CAPÍTULO 1}

\subsection{Abordagens conceituais}

Para compreender como os atores se inserem na construção dos eventos, é necessário que se tenham delimitados os conceitos e como eles são trabalhados no contexto da pesquisa. Os partidos políticos se apresentam como instituição de grande relevância nos Estados Unidos e, então, antes de entrar na análise das fontes, pretende-se perceber como o conceito de 'partido político' é tratado na literatura e como é relacionado a esse contexto específico. Da mesma forma, deve-se proceder com as interpretações ao conceito de 'crise', tanto no âmbito político quanto no econômico.

\subsubsection{Partido Político}

Bobbio (1987) disserta sobre a importância de estudos relacionados ao Estado e suas instituições, com a finalidade de reconstruir o processo de formação do Estado moderno e contemporâneo. Segundo o autor, há uma relação de demanda e resposta entre o conjunto das instituições políticas e o sistema social e, assim, a função das instituições é de apresentar respostas às demandas da sociedade, como em momentos de crise, por exemplo.

Os partidos políticos são instituições políticas que fazem parte do subsistema do Estado e Sartori (1982) afirma que sua função fundamental é de articulação, comunicação e implementação das necessidades dos governados. Isto se encaixa nas relações de demanda e resposta apresentadas por Bobbio (1987) e pode ser entendida como primordial à medida que as democracias se tornam mais complexas. Berstein (2003) afirma que os partidos surgem quando é atingido um certo estágio de desenvolvimento na sociedade, que coincide, segundo Bobbio (1987), com o aumento dos direitos políticos, como a ampliação do sufrágio popular.

Duverger (1980, p.20) concorda com a ideia de relação entre o desenvolvimento dos partidos políticos e da democracia, ao afirmar:

\footnotetext{
Quanto mais as assembleias políticas vêm desenvolver-se suas funções e sua independência, tanto mais os seus membros se ressentem da necessidade de se agruparem por afinidades a fim de agirem de comum acordo; quanto mais o direito de voto se estende e se multiplica, tanto mais se torna necessário enquadrar os eleitores por comitês capazes de tornar conhecidos os candidatos e de canalizar os sufrágios em sua direção.
}

Michels (1982) também percebe a relação inerente entre a formação de partidos e o desenvolvimento político da sociedade. Segundo o autor, não é concebível a ideia de 
democracia sem organização. A vontade coletiva e a ação comum somente seriam possíveis através da canalização de agremiações. Além disso, Michels disserta sobre a impossibilidade de um governo direto das massas e da necessidade da profissionalização dos políticos, com especialização técnica dentro dos partidos.

Para aprimorar o entendimento sobre o conceito de partidos políticos, convém averiguar como a literatura analisa suas definições, critérios e origens.

Sartori (1982) procura criar uma definição mínima para partidos políticos, de modo que englobe as características comuns entre os diversos tipos partidários e afaste as especificidades. O autor afirma que 'partido’ se difere de: facção, movimento político, associação política e grupo de pressão ou de interesse. Assim, a delimitação para que uma organização seja classificada como um partido político é: "um partido é qualquer grupo político identificado por um rótulo oficial que apresente em eleições, e seja capaz de colocar através de eleições (livres ou não) candidatos a cargos públicos” (SARTORI, 1982, p.85).

Sartori (1982) constrói uma análise para diferenciar partidos de facções e demonstrar como os partidos políticos auferiram sua legitimidade para não serem vistos negativamente, como as facções. Semanticamente, os dois termos têm origens diferentes e, segundo o autor, facção transmitia a ideia de comportamento excessivo e impiedoso, enquanto que partido, que vem do latim partire (dividir), não estava presente no vocabulário político até o século XVII.

O conceito de 'seita' era um termo que já existia e também transmitia a ideia de dividir (do latim secare, que significa separar, cortar), e então 'partido' pode ser também derivado etimologicamente de parte, que pode ser entendida a partir do francês partager (partilhar) e do inglês partaking (participação, partilha). A ideia de 'partido', dessa forma, tem a conotação tanto de dividir quanto de participação, e passa a ter uma significação menos negativa do que 'facção' (SARTORI, 1982, p.24-25).

Ademais, os partidos políticos, segundo o autor, se desenvolveram mais como uma prática do que como uma teoria e, portanto, a expressão se torna positiva (ao contrário das facções) por indicar uma entidade nova. Tais grupos passam a ser vistos, no século XIX, como inevitáveis às democracias representativas contemporâneas. E à medida que as eleições se tornam mais 'reais' e os sufrágios são ampliados, os partidos se tornam mais estáveis, processo este que Sartori denomina como ‘solidificação do partido’ (SARTORI, 1982, p.43-46).

Adicionalmente, o autor classifica três tipos básicos de partidos políticos: o partido que se encontra fora da esfera do governo e não se envolve nela; o partido que opera no âmbito do governo, mas sem governar; e o partido que realmente governa, assumindo as funções 
governamentais (SARTORI, 1982). Este último, no caso, foi o modelo que esteve presente nos Estados Unidos desde o princípio da formação do sistema partidário.

Os partidos atendem a três funções: de expressão, canalização e comunicação, sendo que elas estão em interação entre si. A função expressiva indica não apenas 'transmissão de informações', mas sim a ideia de que os partidos “transmitem reivindicações apoiadas por pressões" (SARTORI, 1982, p.49), ou seja, não é somente uma transferência de demandas, as agremiações também colocam o seu peso nas reivindicações. As predileções das massas são transformadas, então, em políticas públicas. Assim, pode ser explanada a função de canalização, em que os partidos agregam, selecionam e modelam a vontade pública, e não apenas a refletem.

A comunicação é o requisito mais básico percebido, ou seja, que ocorre inclusive em formações políticas apartidárias. A diferença entre as três funções consiste em seus níveis de abstração, variando do mais geral para o mais específico. Nas palavras de Sartori (1982, p.79), "todas as formações políticas partilham da propriedade de comunicação; todas as formações partidárias partilham da propriedade de canalização, mas apenas os sistemas partidários partilham da propriedade de expressão". Por sistema partidário o autor entende como um sistema de canalização livre no qual a expressão predomine sobre a repressão ${ }^{5}$.

Por fim, Sartori (1982, p.86-89) aponta a questão de como fazer com que a parte - no caso o partido, no momento em que o sistema se institucionalizou - não ameace a unidade, e sim seja usada em benefício do todo. Dessa forma, o autor sustenta que a estrutura 'parte-todo' ressaltando o pluralismo político, que segundo o autor seria a base da democracia ${ }^{6}$.

Duverger (1980, p.20-33) diferencia dois tipos de partidos políticos, de acordo com sua origem: os de criação eleitoral e parlamentar e os de origem externa ao parlamento. Os primeiros nascem a partir de grupos parlamentares, que organizam comitês eleitorais de modo que se estabeleça uma ligação com a massa de eleitores. Os segundos são estabelecidos por instituições pré-existentes, tais como igrejas, sindicatos e cooperativas agrícolas, e geralmente são mais coerentes e disciplinados que os primeiros.

\footnotetext{
${ }^{5}$ Ou seja, nessa definição não se enquadram modelos unipartidários, uma vez que se pressupõe que a canalização e a expressão sejam vias de mão dupla. Na comunicação expressiva, os cidadãos se comunicam com o Estado, enquanto que nas formações unipartidárias o Estado possui um canal para se comunicar com a sociedade, sem aceitar o processo inverso.

${ }^{6}$ Sartori define pluralismo político como "diversificação do poder", em que se pressupõe a existência de uma "pluralidade de grupos que são ao mesmo tempo independentes e não-inclusivos". O autor defende a ideia de dissensão, que teria tanto do consenso como do conflito, porém sem coincidir com nenhum dos dois conceitos. $\mathrm{O}$ modelo pressupõe que haja consenso sobre questões fundamentais e conflito quanto às políticas adotadas, e que isso daria dinamismo ao sistema político, uma vez que a competição partidária aumentaria a eficiência do Estado (SARTORI, 1982, p.35-37).
} 
A estrutura dos partidos é heterogênea, sendo possível classificar vários tipos sociológicos sob a mesma denominação. Os tipos básicos apontados por Duverger (1980, p.3538) seriam os partidos 'burgueses do século XIX', os partidos socialistas da Europa continental, os partidos comunistas e fascistas, além de outras modalidades como os católicos, trabalhistas, agrários e democrata-cristãos.

Sobre o primeiro tipo apontado, Duverger (1980, p.35) afirma:

O primeiro corresponde quase aos partidos "burgueses" do século XIX que ainda
sobrevivem sob a forma de partidos conservadores e liberais: nos Estados Unidos,
continuam a ocupar, sozinhos, o cenário político (contudo, os partidos norte-
americanos conservam características nitidamente originais). Repousam em comitês
pouco amplos, assaz independentes uns dos outros, geralmente descentralizados; não
procuram multiplicar seus partidários nem enquadrar grandes massas populares, mas
antes agrupar personalidades. Sua atividade é orientada inteiramente para as eleições
e as combinações parlamentares, daí conservando um caráter semi-sazional; seu
arcabouço administrativo é embrionário; sua direção permanece grandemente nas
mãos de deputados e apresenta uma forma individual muito acentuada: o verdadeiro
poder pertence a tal ou tal grupo congregado em torno de um líder parlamentar, e a
vida do partido reside na rivalidade desses pequenos grupos.

Duverger (1980) também classifica os partidos, conforme sua estrutura, como diretos ou indiretos. Nos partidos diretos, os adeptos formam a comunidade partidária sem intermédio de outros grupos sociais, e os partidos indiretos são formados a partir de grupos sociais de base (como grupos profissionais, socialistas, católicos e agrários). Além disso, afirma que um partido consiste em um conjunto de grupos disseminados pelo país, e que os 'elementos de base' designam as células componentes do organismo partidário. Os quatro tipos de elementos de base principais definidos pelo autor são comitê, seção, célula e milícia.

O comitê possui caráter restrito, com pequeno número de membros, sem a pretensão de crescer numericamente, funciona em uma grande área geográfica, os membros são selecionados por sua qualidade técnica e influência e tem caráter semipermanente, atuando principalmente em época de eleições (DUVERGER, 1980).

Nos Estados Unidos, segundo o autor, pode-se considerar que os partidos são formados à base do comitê e possuem uma estrutura de conjunto arcaica, uma vez que os comitês não foram substituídos por seções ou células, e pelo fato de que o ingresso das massas na política não acarretou o surgimento de um partido de esquerda de estrutura moderna. Acerca da estrutura partidária nos EUA, Duverger (1980, p.57) discorre: 
Os partidos norte-americanos são, antes de tudo, máquinas eleitorais, que asseguram a designação dos candidatos em espécies de pré-escrutínios oficialmente organizados pelas leis dos Estados relativas às convenções ou às primárias: constituem nesse sentido organismos inteiramente originais. Por outro lado, não revestem o caráter de agrupamentos ideológicos ou de comunidades de classe: através do imenso território da União, cada um deles reúne pessoas de opiniões muito diferentes e de situações muito diversas. Trata-se no fundo de equipes de técnicos da conquista de votos e de postos administrativos proporcionados pelo spoil system ${ }^{7}[\ldots]$.

A seção é um elemento menos centralizado, uma parte do todo - sua existência isolada não é concebível. Duverger (1980) classifica-as como sendo opostas ao comitê, por se preocupar com a quantidade de membros e recorrer à massa, ao invés de pessoas influentes selecionadas. É vista como uma 'invenção socialista', e quando os partidos conservadores adotam o sistema de seções é com a finalidade de democratizar o partido.

A célula é formada por grupos menores que o das seções, com base profissional (os adeptos são reunidos por local de trabalho), e sua estrutura facilita a ação clandestina. Já a milícia tem caráter de exército privado e os membros são submetidos a disciplina e treinamento de soldados, além de vários elementos simbólicos característicos de organizações militares, como uniformes, insígnias e marchas, sendo formada por grupos pequenos de base (DUVERGER, 1980).

Ademais, Duverger (1980) afirma que os partidos políticos alteraram a dinâmica dos sistemas políticos. As eleições foram modificadas pelo desenvolvimento dos partidos, pois se insere um terceiro elemento, um intermediário entre o eleitor e o eleito. $\mathrm{O}$ autor define bem esse fenômeno com as seguintes palavras: "antes de ser escolhido pelos eleitores, o deputado é escolhido por sua agremiação: os eleitores só fazem ratificar essa escolha"8 (DUVERGER, 1980, p.387).

Em contraposição aos autores clássicos, Angelo Panebianco (2005) aponta a existência de dois preconceitos na literatura sobre partidos, o sociológico e o teleológico. O preconceito sociológico considera as atividades dos partidos como produto das demandas de grupos sociais. Dessa forma, tem a tendência de interpretar os conflitos partidários como conflitos entre representantes de interesses sociais distintos. Porém, Panebianco afirma que antes das desigualdades sociais é preciso observar as desigualdades organizativas, dentro do partido, o que representa a principal causa dos conflitos intrapartidários.

\footnotetext{
${ }^{7}$ Na política de spoil system, após as eleições presidenciais eram oferecidos cargos administrativos aos partidários do candidato vitorioso.

${ }^{8}$ Nos Estados Unidos, há um pré-escrutínio para a escolha dos candidatos - as primárias, que acontecem em alguns estados, dependendo da legislação específica de cada um. Esse tipo de modelo se aproximaria da democracia clássica, segundo Duverger, uma vez que acontece uma votação previamente às eleições gerais para a escolha dos candidatos. Porém esse pré-escrutínio não é puro, há a influência dos dirigentes do partido e muitas vezes essa eleição é limitada a uma categoria restrita de cidadãos (DUVERGER, 1980, p.388).
} 
O preconceito teleológico apresenta a ideia de que os partidos são voltados para a realização de objetivos específicos. Tal preconceito dá origem a duas versões, a primeira em relação a definições ligadas às metas ideológicas dos partidos e a segunda resultando em definições mínimas, que são feitas para apresentar objetivos comuns a qualquer agremiação. $\mathrm{O}$ autor, assim, se contrapõe às teses de Sartori e Duverger, que se preocupam em fornecer definições e encaixar tipos partidários em padrões. A realidade dos partidos políticos é mais complexa do que a necessidade de catalogação sentida pelos autores tradicionais.

Berstein define partido como fundamentalmente "o lugar onde se opera a mediação política" (BERSTEIN, 2003, p.60). Pode-se perceber uma convergência desta definição com a função de canalização defendida por Sartori (1982), em que os partidos seriam um canal intermediário entre o governo e a sociedade. A mediação, segundo Berstein, estaria situada no espaço entre o problema e o discurso e os partidos então teriam a função de traduzir as necessidades da população para a linguagem da política. Mais adiante será abordada novamente essa questão, mostrando a relação de reformulações partidárias com momentos de crise e comparando com a teoria de demandas de participação de Bobbio (1998).

De acordo com Berstein, é necessário traçar critérios para diferenciar os partidos de outros tipos de organizações políticas. Assim, a partir dos estudos dos cientistas políticos americanos La Palombara e Weiner, são definidos quatro critérios principais: duração no tempo, ou seja, existência superior à vida dos fundadores; extensão no espaço, com estruturas nacionais e locais; aspiração ao exercício do poder e vontade de buscar o apoio da população, angariando votos de eleitores e através do recrutamento de militantes (LA PALOMBARA; WEINER, 1969 apud BERSTEIN, 2003, p.62-63).

Bobbio (1998), no Dicionário de Política, define como partidos políticos organizações que se associam com o fim de participar na gestão do poder público, e afirma que esse tipo de instituição surge quando é reconhecido o direito ao povo de ter participação no poder. A característica comum, então, de associações que se reconhecem como esse tipo de agremiação é a aspiração de se moverem na esfera do poder político.

Bobbio (1987), em sua obra Estado, Governo e Sociedade, alega, assim como Duverger (1980), que a constituição de partidos organizados foi responsável por uma modificação na estrutura do Estado representativo, uma vez que são associações que coordenam as eleições. $\mathrm{O}$ autor defende que nesses sistemas políticos partidários os eleitores se identificam mais com um partido do que com os candidatos, e então há a hipótese da transformação de Estado representativo em 'Estado de Partidos', no qual os sujeitos políticos mais relevantes não são mais os indivíduos, mas sim grupos organizados. Nota-se com mais clareza esse cenário em 
países em que a presença partidária é forte e decisiva, e pode-se considerar os Estados Unidos como o principal exemplo desse tipo de modelo.

Weber (2000) também concorda com a premissa de que o sistema partidário altera a dinâmica dos regimes políticos e afirma que a emergência dos partidos pode ser associada à constante burocratização do Estado contemporâneo, uma vez que o poder passa a estar cada vez menos relacionado a uma pessoa central e carismática e cada vez mais institucionalizado. Nos Estados Unidos, observa-se que é comum as pessoas se identificarem mais com a sigla do que com determinado candidato, tanto em cargos presidenciais quanto do Legislativo. Bourdieu (2014, p.185), analisando os estudos de Norbert Elias, assente similarmente com essa institucionalização do poder e disserta a respeito da despersonalização do exercício do poder, que amplia a cadeia burocrática e conduz para uma rede de interdependência entre os membros da sociedade.

Bourdieu (2014, p.225-239), além disso, discorre sobre o 'poder simbólico', em que as relações de força são essencialmente relações de comunicação, e assim analisa o poder do Estado em ser obedecido. Bobbio (1987) afirma sobre a distinção entre o poder coativo do Estado e o poder das palavras, dos gestos e dos símbolos. Para Bourdieu (2014), as forças simbólicas são princípios de construção social. O Estado, segundo o autor, tem a capacidade de ordenar a sociedade sem exercer coerção permanente (devido à sua legitimidade), o que é traduzido em uma eficácia simbólica. Nessa perspectiva, pode-se entender o partido político como uma instituição que formula os termos simbólicos que justificam a ação do Estado, e que a sociedade acata tais ações em virtude de uma ‘acumulação de capital simbólico'.

Os partidos políticos, conforme já abordado por Berstein (2003), possuem a função de mediação entre a sociedade e o governo, e a partir disso se tornam referência simbólica para a população, que buscam neles uma representação para suas demandas. O desenvolvimento do sistema representativo do Estado potencializou essa associação, uma vez que a personificação do poder diminuiu, dando lugar a uma maior institucionalização. A instituição que faz a canalização entre a sociedade e o Estado é o partido e, portanto, pode-se entende-lo como detentor desse simbolismo.

Ademais, pode-se analisar a hipótese em que os partidos formulam os termos simbólicos e justificam ações políticas do governo uma vez que há a pretensão de manutenção do Estado. Como já foi apontado, os partidos aspiram o exercício do poder, e para isso é fundamental que haja a preservação do regime. As agremiações podem ser consideradas intermediários simbólicos das políticas de governo. 


\subsubsection{Revisão conceitual de 'crise'}

Além do conceito, estrutura e origem dos partidos políticos, convém verificar como a literatura trata o conceito de crise, ainda mais quando ela pertence ao campo político. Uma de suas possíveis derivações é a formação de novos grupos, materializados em agremiações partidárias.

Koselleck (2006) aborda a questão do conceito de crise do ponto de vista de sua evolução léxica. A sua concepção surgiu com os gregos, inicialmente nas áreas de teologia, medicina e direito, e transmitia a oposição de escolhas entre alternativas extremas. A partir do século XVII, o termo expandiu-se para a política, economia, história e psicologia, sendo posteriormente bastante aplicado em referências às Revoluções Francesa e Americana. Na História, de acordo com o autor, 'crise' passaria a representar um novo senso de tempo, indicando e intensificando o fim de um período.

Segundo o autor, as interpretações econômicas para o conceito de crise datam da metade do século XIX, e foram vistas como ocorrências causadas pelo próprio sistema capitalista. Teorias de crises econômicas começam a influenciar percepções políticas e sociais. Assim, ‘crise' passa a aparecer como um conceito chave na história, usado para caracterizar períodos ou estruturas (KOSELLECK, 2006).

Fernand Braudel (1987) identifica as crises como parte da estrutura do capitalismo. O autor classifica o conceito de 'economia-mundo' como a economia de uma porção do planeta, na medida em que essa parte compõe um 'todo econômico'. A 'economia-mundo', segundo Braudel, se reparte em zonas, formadas pelo núcleo central, as zonas intermediárias e as margens.

As crises nas estruturas operariam 'descentragens' e 'recentragens' da 'economiamundo', ou seja, o deslocamento de centro deste sistema. $\mathrm{O}$ autor afirma que, então, a crise de 1929 se estabeleceria, nessa hipótese, como principal fator da 'recentragem' da economia mundial nos Estados Unidos, saindo do polo da Inglaterra.

Candeias (2011) concorda com a visão estruturalista de Braudel (1987) e afirma que as crises são naturais em sociedades em que o capitalismo é o sistema que prevalece. $\mathrm{O}$ autor define crises orgânicas como sendo caracterizadas por uma condensação e entrelaçamento de várias crises. Nessa definição, segundo Candeias, são englobados tanto eventos econômicos quanto políticos.

Muito se associa a formação dos partidos políticos a crises políticas. Nos Estados Unidos, a consolidação do Partido Republicano é um exemplo dessa relação, uma vez que se 
originou devido a várias adversidades tanto políticas quanto econômicas na década de 1850 . As crises geram alterações na dinâmica dos regimes de governo do Estado, e reformulam os paradigmas e as identidades das instituições políticas.

Em democracias em que o sistema partidário é bem desenvolvido, tal como nos Estados Unidos $^{9}$, que se encontra como objeto de análise, é possível perceber como crises políticas, econômicas ou de representatividade afetam a dinâmica desse sistema. A estrutura do sistema partidário reflete os alicerces do próprio Estado, então variações partidárias ocasionadas por fenômenos associados a crises são relevantes para determinar as oscilações nas dinâmicas políticas. As demandas da sociedade também são pertinentes, uma vez que são refletidos por posturas adotadas pelos partidos, a partir dos canais de expressão e canalização (SARTORI, 1982).

Bobbio (1998) disserta sobre a importância dessa influência da população nas alterações das estruturas políticas do Estado. $\mathrm{O}$ autor a denomina pelo conceito de 'demanda de participação', que ocorre por parte de estratos da sociedade no processo de formação das decisões políticas. Para o jurista, tal demanda se intensifica nos momentos de transformações econômicas e sociais. Pode-se notar, assim, tal intensificação das demandas de participação nos momentos de crise e transformações sociais, que culminam na modificação das relações de poder. Nesses períodos de alterações políticas, percebe-se a necessidade de novas organizações no sistema partidário.

Berstein (2003) também associa a emergência de crises com modificações no sistema político e partidário. O autor, analisando os estudos de La Palombara e Weiner, afirma que as crises se conceituam como rupturas que justificam a emergência de organizações que traduzam as demandas e tendências de opinião e sejam capazes de criar novas políticas (LA PALOMBARA; WEINER, 1969 apud BERSTEIN, 2003, p.67).

Além disso, o historiador concatena o surgimento dos partidos modernos com fenômenos estruturais inseridos na longa duração, o que aponta um pensamento similar ao de Braudel (1987) a respeito de crises estruturais. As agregações e desagregações no sistema políticos estão ligadas, então, a alterações na estrutura, que podem ser analisados a partir de estudos em recortes temporais de longo prazo.

Ademais, como crise o autor entende que diversos fatores podem ser responsáveis pela alteração da estrutura política, tais como guerras, fenômenos econômicos, alterações

\footnotetext{
${ }^{9}$ Pode considerar-se que o sistema partidário é bem desenvolvido nos Estados Unidos devido ao seu antigo estabelecimento, desde o final do século XVIII, sendo um dos primeiros países a consolidarem os partidos em seu sistema político.
} 
demográficas, crises de legitimidade e de participação, entre outros. Os partidos, conclui Berstein, sobrevivem com a condição de responder a problemas fundamentais colocados pela sociedade, o que pode ser entendido de maneira similar à abordagem de Bobbio (1998) a respeito da influência das demandas de participação na reformulação das organizações políticas.

A importância dos estudos de longo prazo apontada por Berstein (2003) pode ser apoiada na teoria sobre longa duração de Braudel (1969), que disserta sobre novas formas de narrativa histórica através do estudo das estruturas. Para construir os aspectos das identidades dos partidos em determinado período, é necessário analisar as variáveis que influenciaram as tomadas de decisões em momentos anteriores. Procura-se estudar os fatores que constituíram os modelos adotados pelos partidos para melhor compreender suas ações diante de transformações.

\subsection{Ciclos na política norte-americana}

O historiador Arthur Schlesinger Jr. (1992) sistematiza a política norte-americana em ciclos de alternância de poder. $\mathrm{O}$ autor inicia a análise afirmando que na história se observam padrões de oscilação, de fluxo e refluxo, e reconstrói os estudos feitos por pensadores anteriores até consolidar sua teoria.

Schlesinger Jr. analisa primeiramente os apontamentos de Henry Adams (ADAMS, 1889-1891 apud SCHLESINGER JR., 1992), que aplicou uma tese cíclica aos primeiros anos da República norte-americana. Os ciclos tinham duração de aproximadamente 12 anos e descreviam a oscilação de um pêndulo, alternando entre a centralização e a difusão da energia nacional.

Em seguida, é observada a teoria de seu pai, Schlesinger, que aponta a intercalação entre o conservadorismo e o liberalismo; entre momentos de avanço democrático e outros de contenção (SCHLESINGER, 1949 apud SCHLESINGER JR., 1992). Sistematizando, os ciclos propostos pelo autor são os seguintes:

- 1829-1841: Democracia de Jackson

- 1841-1861: Dominação do governo nacional pelos escravocratas

- 1861-1869: Abolição da escravatura

- 1869-1901: Governo conservador

- 1901-1919: Era Progressista

- 1919-1931: Restauração republicana

- 1931-1947: Era do New Deal 
O primeiro ciclo é iniciado pelo governo de Andrew Jackson, que foi marcado pela expansão da fronteira, pela remoção dos índios, pelo surgimento de tarifas protecionistas e pelo desenvolvimento acelerado da indústria no Norte. Em seguida, a próxima fase foi marcada pelo expansionismo territorial e aumento do poder político dos latifundiários escravocratas.

Conflitos envolvendo a questão da escravidão deram início à Guerra de Secessão com a vitória de Abraham Lincoln para a presidência, colocando fim ao domínio do Partido Democrata e iniciando o período de reconstrução. Karnal (2007, p.137) define esse período pósguerra como a emergência do 'modelo do Norte'.

O ciclo seguinte, do conservadorismo, foi marcado pela segregação e violência racial, e Karnal (2007) analisa que a supremacia branca era reforçada pelo imperialismo norteamericano. Além disso, segundo o autor, o governo priorizou a 'harmonia social' em detrimento da igualdade de direitos. Os republicanos ocuparam a presidência durante quase toda a era, sendo interrompido apenas pelos dois mandatos de Grover Cleveland (1885-1889 e 18931897).

A Era Progressista ficou marcada pela ascensão econômica dos Estados Unidos, alta produção industrial, grandes monopólios, imigração massiva e projetos imperialistas. Sobre o período, Karnal (2007, p.176) analisa:

Essa época, que mais tarde foi chamada "progressista", viu diversas campanhas defenderem o argumento de que só um Estado atuante e socialmente consciente podia garantir medidas de justiça social e manter a ordem num país em franca mudança. Porém, o impulso progressista era cheio de contradições que ficariam evidentes durante a Primeira Guerra Mundial, quando o novo Estado intervencionista viria usar seus poderes para violentamente arrasar seus críticos mais radicais.

Depois da Primeira Guerra, o Partido Republicano retomou sua primazia na presidência, em que permaneceu durante toda a década de 1920. O momento foi caracterizado por grande crescimento econômico e financeiro, produção em alta, preços estáveis e redução do desemprego. O período era de euforia e crescimento do consumismo. Com as altas taxas de especulação nos mercados financeiros, a etapa do progresso foi interrompida pela Crise de 1929, dando início à Grande Depressão.

Por fim, o último ciclo apresentado é o do New Deal. Diante da incapacidade do Partido Republicano em lidar com a crise de grandes proporções, Franklin Delano Roosevelt, do Partido Democrata, é eleito e inicia uma série de políticas anticíclicas para controlar a depressão. A partir de então, os democratas assumem a preponderância na presidência.

A duração média dos ciclos era de dezesseis anos e meio, com um desvio no período de 1861 a 1901: a Guerra Civil e a Reconstrução aceleraram o tempo, provocando intensas 
mudanças em um curto prazo (1861-1869), seguida de um longo período de reação e repressão de 1869 a 1901. A representação, ao invés de pêndulo, se daria através de um espiral, uma vez que a alternância permite a acumulação das mudanças.

Hisrchman (1982 apud SCHLESINGER JR., 1992, p.28) defende a alternância no ciclo entre 'interesse privado' e 'atividade pública'. Schlesinger Jr. desenvolve a sua teoria a partir dessa definição. O autor afirma que o ciclo é autogerador, e que cada nova fase flui das condições e contradições da fase anterior. Além disso, defende a independência do ciclo político e sustenta que outros fatores, como guerras, depressões e inflações podem intensificar as mudanças, mas que o ciclo em si é autônomo.

Para argumentar em prol da autonomia do ciclo político, Schlesinger Jr. (1992, p.29-30) afirma:

A independência do ciclo político é confirmada pela ausência de correlação mesmo com algo tão poderoso no impacto quanto o ciclo comercial. A depressão introduziu o New Deal, mas a Era Progressista começou em um período de prosperidade geral, e duas dolorosas depressões ocorreram entre 1869 e 1901 sem reverter o crescimento da vaga de conservantismo.

A alternância entre períodos de domínio do interesse público e outros de prevalência do interesse privado se explicam, segundo o autor, pelo esgotamento das eras políticas, o que gera o desejo de mudanças. Cada fase tem suas contradições específicas; a ação pública direciona um grande número de mudanças em um curto período de tempo. Schlesinger Jr. (1992, p.31) classifica uma ação pública como ‘emocionalmente exaustiva' e, assim, a fase de predomínio do interesse privado se inicia como recuperação da era intensa de interesse público. Os períodos de interesse privado fundavam-se na ideia de que ao promover seus próprios interesses, estaria promovendo o interesse geral ${ }^{10}$ (SCHLESINGER JR., 1992, p.45).

Schlesinger Jr. (1992) ainda analisa como mola do ciclo político a dimensão das gerações. Uma geração tem duração política de aproximadamente trinta anos, em que os primeiros quinze são dedicados a atingir uma maturidade e questionar a geração vigente, para então chegar ao poder e ficar os próximos quinze anos, momento em que começa a ser questionada pela geração seguinte.

Relacionando a tese dos ciclos com a dinâmica dos partidos políticos nos Estados Unidos, Schlesinger Jr. (1992) disserta sobre a teoria do realinhamento partidário periódico. Segundo o autor, há no sistema político norte-americano um partido majoritário e um minoritário, cada qual com seu conjunto de programas. Ao longo do tempo, questões dividem

\footnotetext{
${ }^{10}$ Tal como a concepção de que o livre mercado contribui para o crescimento econômico e, consequentemente, para o aumento do bem-estar da população.
} 
internamente os partidos e confrontam o modelo partidário estabelecido. Quando ocorre uma alteração fundamental na orientação política, ocorre um realinhamento das forças políticas e um novo paradigma para a divisão de poder entre as agremiações.

Schlesinger Jr. cita a análise de Samuel Lubell, que exemplifica o ciclo partidário norteamericano a partir de uma metáfora astronômica, em que não se verificam dois 'sois', mas sim um sol e uma lua que se alternam. Sobre essa alegoria, nas palavras de Lubell (1952 apud SCHLESINGER JR., 1992, p.38):

É no seio do partido majoritário que se destrincham as questões de qualquer período
determinado. Enquanto isso, o partido minoritário brilha na radiação refletida do calor
assim gerado... Cada vez que um sol majoritário se põe e outro sol se levanta, o drama
da política americana se transforma. Literal e figurativamente, uma nova era política
começa, porque todo novo partido majoritário traz sua própria órbita de conflito, seu
próprio ritmo peculiar de antagonismos étnicos, seu próprio equilíbrio econômico e
setorial.

A tradição política dos Estados Unidos é moldada pela alternância bipartidária nos ciclos. Este modelo, então, identifica cinco eras eleitorais com duração aproximada de 30 anos para cada: 1800 a 1828; 1828 a 1860 (inaugurada a partir da Democracia de Jackson); 1860 a 1896 (primazia Republicana); 1896 a 1932 (Solid South do Partido Democrata e conquista da maioria pelos republicanos em todo o país); e 1932 a 1945 (New Deal). Assim, ao analisar a estrutura partidária pensando sobre os ciclos políticos, é possível construir uma narrativa acerca de determinados momentos da história norte-americana.

Dessa forma, considera-se a oscilação entre momentos de conservadorismo e reforma, interesse privado e dedicação pública como formadora da dinâmica política dos Estados Unidos. Pretende-se, então, nesse primeiro capítulo, perceber brevemente como se deu o comportamento dos partidos políticos Democrata e Republicano nos seguintes períodos: anterior à Guerra de Secessão, com as questões abolicionistas (década de 1850) e da crise econômica de 1873, de modo a formular o cenário norte-americano do século XX.

Esses dois períodos supracitados são importantes como contextos para compreender a construção das dinâmicas partidárias. O primeiro momento representa a consolidação do bipartidarismo, com a formação do Partido Republicano e início de um longo ciclo de sua preponderância. A crise de 1873 foi a mais intensa do século XIX e pode ser considerada como uma precursora da Grande Depressão da década de 1930. Apesar de tais acontecimentos não serem o foco do presente trabalho, é relevante considerar seus impactos para o desenvolvimento das ideias políticas econômicas dos partidos no século seguinte. 
Serão exploradas como fontes primárias as Plataformas dos partidos nesses períodos, de modo a identificar convergências e divergências de posições entre os dois grupos nas questões relevantes e verificar possíveis mudanças de identidade e paradigmas.

\subsection{A formação do Partido Republicano e a consolidação definitiva do bipartidarismo nos Estados Unidos}

A década de 1850 representou um período de reformulação do sistema partidário. Com a desarticulação do Partido Whig depois de 1852, o Partido Democrata não contava com uma oposição forte. Em 1848, Zachary Taylor, Whig, venceu tanto as eleições populares quanto as do colégio eleitoral, com uma margem considerável de $47,28 \%$ a $42,49 \%$ e $56,2 \%$ a $43,8 \%$, respectivamente (THE AMERICAN PRESIDENCY PROJECT, 2016a). Em 1852, contudo, o Partido Whig, apesar de bons números nas eleições populares, sofreu uma derrota devastadora no Colégio Eleitoral (conforme pode-se atestar no mapa e na tabela seguintes). A desintegração do partido foi então inevitável, estimulada por desarticulações internas.

Imagem 1 - Resultado das eleições de $1852^{11}$

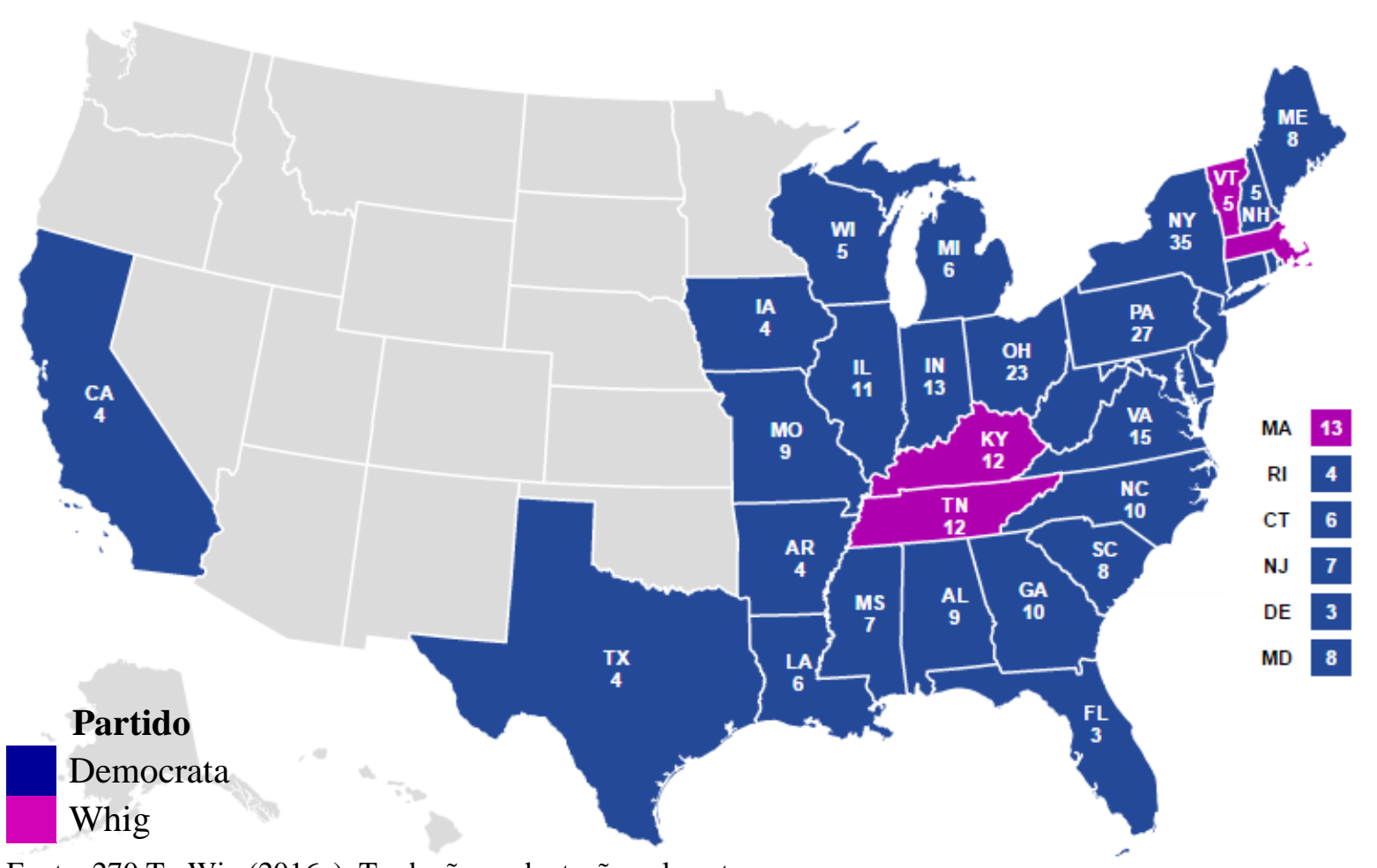

Fonte: 270 To Win (2016a). Tradução e adaptação pela autora.

${ }^{11}$ Todos os mapas apresentados nesta dissertação apresentam o número de cadeiras no Colégio Eleitoral em cada estado da União. 
Tabela 1 - Resultado das eleições de 1852

\begin{tabular}{|c|c|c|c|c|c|c|}
\hline Candidato & Vice & $\begin{array}{l}\text { Partido } \\
\text { Político }\end{array}$ & \multicolumn{2}{|c|}{ Votos populares } & \multicolumn{2}{|c|}{$\begin{array}{c}\text { Votos } \\
\text { eleitorais }\end{array}$} \\
\hline Franklin Pierce & William King & Democrata & 1.607 .510 & $50,83 \%$ & 254 & $85,8 \%$ \\
\hline Winfield Scott & $\begin{array}{l}\text { William } \\
\text { Graham }\end{array}$ & Whig & 1.386 .942 & $43,9 \%$ & 42 & $14,2 \%$ \\
\hline John Hale & George Julian & Solo Livre & 155.210 & $4,9 \%$ & 0 & $0,0 \%$ \\
\hline \multicolumn{3}{|c|}{ Total } & 3.161 .830 & $100 \%$ & 296 & $100 \%$ \\
\hline
\end{tabular}

Fonte: The American Presidency Project (2016b). Tradução e adaptação pela autora.

Nesse momento, pequenas agremiações foram ganhando destaque, como os partidos Abolicionista, da Liberdade e do Solo Livre (Free-Soil), porém sem condições de serem competitivos eleitoralmente. Segundo Binkley (1961), os partidos menores condicionam e modificam o cenário dos principais, pois levantam questões a serem abordadas mais livremente do que os maiores.

Um dos fatores responsáveis para a desagregação dos velhos combinados partidários foi a questão da chegada de estrangeiros nos Estados Unidos - vários dos quais europeus dissidentes dos movimentos de 1848. Os trabalhadores locais pressionavam os políticos Whigs a adotarem uma política anti-imigração, enquanto que os democratas confraternizavam livremente com esses estrangeiros, o que passou a pesar na definição das eleições. $O$ Movimento Know Nothing foi um dos principais movimentos nativistas da época e possuía também um viés anticatólico, principalmente por causa da imigração de irlandeses dessa religião para o país.

As questões relativas à abolição da escravidão também foram colocadas, mas não havia o discurso antirracista, a motivação maior era aumentar a competitividade para os trabalhadores livres entrarem no mercado. O Partido do Solo Livre, que defendia a concessão de terras do Oeste para trabalhadores livres, tinha uma repugnância pela presença do negro, e por isso queria tirá-los dessas terras.

A emergência desses grupos com interesses próprios neste período exemplifica o que Bobbio (1998) conceitua como demandas de participação, conforme explicitado anteriormente, que se intensificam nos períodos de transformações políticas, econômicas e sociais. Tais demandas reformularam o cenário político dos Estados Unidos, remodelando o sistema partidário com a constituição e ascensão do Partido Republicano, o que daria início ao primeiro ciclo de primazia do partido.

Binkley (1961) caracteriza a formação do Partido Republicano como um fenômeno ímpar na história dos Estados Unidos, pelo fato de ter-se originado espontaneamente, sem o 
auxílio de um líder nacional notável. Abraham Lincoln, considerado posteriormente como um dos principais ícones do partido, ainda não era importante, tendo tido pouca participação na sua fundação.

O partido nasceu do conjunto de várias lideranças políticas, com um discurso de 'partido de reforma' e oposição ao governo democrata de Franklin Pierce. Este presidente foi bastante impopular, seus atos renderam pesadas críticas, especialmente a Lei Kansas-Nebraska e a defesa da anexação de Cuba como um estado escravocrata. Ademais, Pierce nomeou Jefferson Davis como Secretário de Guerra, sulista que seria o futuro Presidente da Confederação, indicando claramente que a administração estava estreitamente comprometida com os interesses do Sul (JOHNSON, 1997).

Segundo Izecksohn (2003), a repercussão das controvérsias dos atos do governo do presidente proporcionou um realinhamento partidário entre os descontentes do Norte. $\mathrm{O}$ surgimento do Partido do Solo Livre (Free-Soil) e depois do nativista Partido Americano (Know Nothing) aponta para esses reagrupamentos. Porém, essas organizações careciam de força para congregar uma coalizão mais sólida. Assim, finalmente, com a criação do Partido Republicano, houve a substituição da maioria democrata por uma maioria antidemocrata, principalmente no Norte. O partido agregava pequenos e médios fazendeiros, além de industriais e comerciantes.

Diversas lideranças que eram contrárias à Lei Kansas-Nebraska (1854, desenvolvida pelo Senador democrata Stephen Douglas) se aproximaram espontaneamente até a formação do novo partido de oposição. O território do Nebraska estava dentro dos limites onde a escravidão havia sido proibida pelo Acordo de Missouri de 1820 - que dizia que a escravidão estaria proibida em todos os territórios ao norte da latitude 36’30 - e, para conseguir apoio para construir uma estrada de ferro transcontinental, fez um acordo com o Kansas, permitindo os territórios acima da latitude do Acordo de Missouri pudessem decidir a questão da escravidão com base na soberania popular. Essa lei ganhou a antipatia do Norte, e os chamados 'antinebraskas' passaram a se reunir num objetivo em comum, que mais tarde culminaria no Partido Republicano.

A Primeira Convenção Nacional Republicana aconteceu em 1856 e, em sua plataforma, são definidas oposições ao governo democrata vigente, conforme se verifica a seguir: 
Esta Convenção de Delegados, reunidos em cumprimento de chamada dirigida ao povo dos Estados Unidos, sem levar em conta as diferenças políticas passadas ou divisões, que se opõem à revogação do acordo de Missouri; à política da atual administração; à extensão da escravidão em Território Livre; a favor da admissão de Kansas como um Estado livre; de restaurar a ação do Governo Federal com os princípios de Washington e Jefferson; e com a finalidade de apresentar candidatos para os cargos de Presidente e Vice-Presidente. (REPUBLICAN NATIONAL CONVENTION, 1856, tradução elaborada pela autora)

Além disso, na Plataforma, entre outras coisas, os republicanos afirmam sobre a importância de manter os princípios da Declaração de Independência e da Constituição Federal e defendem que a União dos Estados deve ser preservada. Binkley (1961) afirma que, dessa forma, há um interesse na volta da memória de Thomas Jefferson, considerado o primeiro 'freesoil' ao defender os axiomas de uma sociedade livre.

Adicionalmente, os republicanos discorrem sobre o direito inalienável à vida, liberdade e propriedade, e citam parte do conteúdo da $5^{a}$ Emenda da Constituição Federal, que diz que “ninguém será privado de vida, liberdade, ou bens, sem processo legal" (ESTADOS UNIDOS DA AMÉRICA, 1787, tradução elaborada pela autora), para afirmar que o propósito de estabelecer escravidão nos territórios dos Estados Unidos viola este princípio. O partido acusa o Governo Federal de crimes contra os direitos da população do Kansas, sendo citados diversos casos que comprovam esses crimes e defendem que o Kansas deve ser admitido como Estado da União, com sua própria Constituição livre (REPUBLICAN NATIONAL CONVENTION, 1856).

Por outro lado, a Plataforma do Partido Democrata de 1856 se posiciona claramente favorável à manutenção da escravidão, afirmando, nas suas resoluções:

Que o Congresso não tem poder, nos termos da Constituição, para interferir ou
controlar as instituições domésticas de vários Estados, e que tais Estados são os juízes
únicos e adequados de tudo pertencente aos seus próprios assuntos não proibidos pela
Constituição; que todos os esforços dos abolicionistas, ou outros, feitos para induzir
o Congresso para interferir na questão da escravatura ou a tomar medidas incipientes
em relação a ela, são calculados para levar a consequências alarmantes e perigosas; e
que todos esses esforços têm uma tendência inevitável para diminuir a felicidade das
pessoas e pôr em perigo a estabilidade e a permanência da União, e não deve ser
tolerada por qualquer amigo de nossas instituições políticas. (DEMOCRATIC
NATIONAL CONVENTION, 1856, tradução elaborada pela autora)

Ademais, se posicionam favoráveis ao cumprimento do Compromisso de 1850, especialmente no tocante ao ato para a recuperação de escravos fugidos, uma vez que tem fidelidade à Constituição e não pode ser revogado ou alterado pois prejudicaria sua eficiência. O Compromisso de 1850 propunha que, em troca do consentimento do Sul a respeito da admissão da Califórnia com uma constituição de Estado livre, o resto do território adquirido do México seria organizado sem menção de escravidão; haveria a abolição do tráfico no Distrito 
de Colúmbia, sem abolição da escravatura; e haveria uma nova lei relativa aos escravos fugidos no Sul, a Lei dos Escravos Fugidos, que permitia aos senhores do Sul ir ao Norte para buscar seus escravos fugidos.

Ainda, a respeito dos territórios do Kansas e Nebraska, declaram:

A democracia americana reconhece e adota os princípios contidos nas leis orgânicas que instituem os Territórios do Kansas e Nebraska como incorporando a solução única e segura para a "questão da escravidão" sobre a qual a grande ideia nacional do povo de todo o país repousa em seu determinado conservadorismo da União. (DEMOCRATIC NATIONAL CONVENTION, 1856, tradução elaborada pela autora)

O Partido Democrata reconhece, por fim, o direito das pessoas de todos os territórios, incluindo Kansas e Nebraska, agindo legalmente e de acordo com a maioria de seus residentes, de formarem uma Constituição com a presença ou não de escravidão, de serem admitidas na União em perfeita igualdade com os outros Estados.

Na Convenção do Partido Republicano, em 1856, não havia ainda um candidato lógico para indicação à presidência, visto que o partido se construiu sem um líder nacional dominante. Lincoln, na época, ainda não era forte, e assim John Frémont foi indicado. O candidato republicano perdeu as eleições, mas conseguiu atrair uma boa quantidade de votos e começar a desestabilizar a supremacia dos democratas, conforme pode-se ver no mapa e na tabela a seguir:

Imagem 2 - Resultado das eleições de 1856

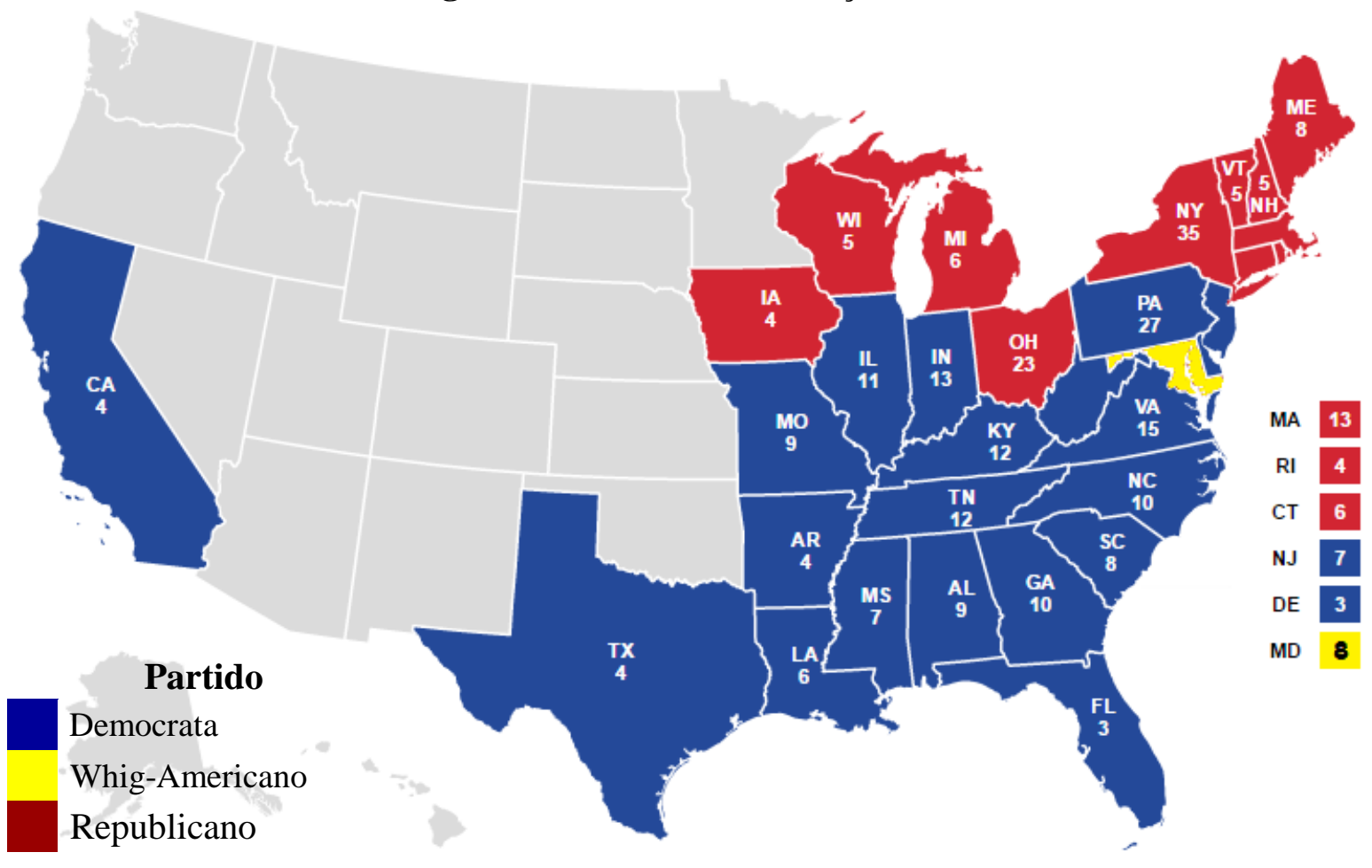

Fonte: 270 To Win (2016b). Tradução e adaptação pela autora. 
Tabela 2 - Resultado das eleições de 1856

\begin{tabular}{|c|c|c|c|c|c|c|}
\hline Candidato & Vice & $\begin{array}{c}\text { Partido } \\
\text { Político }\end{array}$ & \multicolumn{2}{|c|}{ Votos populares } & \multicolumn{2}{c|}{$\begin{array}{c}\text { Votos } \\
\text { eleitorais }\end{array}$} \\
\hline $\begin{array}{c}\text { James } \\
\text { Buchanan }\end{array}$ & $\begin{array}{c}\text { John } \\
\text { Breckenridge }\end{array}$ & Democrata & 1.836 .072 & $45,3 \%$ & 174 & $58,8 \%$ \\
\hline John Frémont & $\begin{array}{c}\text { William } \\
\text { Dayton }\end{array}$ & Republicano & 1.342 .345 & $33,1 \%$ & 114 & $38,5 \%$ \\
\hline $\begin{array}{c}\text { Millard } \\
\text { Fillmore }\end{array}$ & $\begin{array}{c}\text { Andrew } \\
\text { Donelson }\end{array}$ & $\begin{array}{c}\text { Whig- } \\
\text { Americano }\end{array}$ & 873.053 & $21,6 \%$ & 8 & $2,7 \%$ \\
\hline \multicolumn{2}{|c|}{ Total } & 4.054 .647 & $100 \%$ & 296 & $100 \%$ \\
\hline
\end{tabular}

Fonte: The American Presidency Project (2016c). Tradução e adaptação pela autora.

Buchanan, do Partido Democrata, assumiu, mas logo em seguida os Estados Unidos sofreram uma crise econômica - o Pânico de 1857 - com falências comerciais, desemprego e tarifas baixas. A baixa das tarifas atingiu os produtores de lã de Ohio e os manufatores de ferro da Pensilvânia, e eles então vão passar para o Partido Republicano. Além disso, as tensões entre o Norte e o Sul atingiram seu ponto alto, e o presidente tentou impor uma constituição escravista - a Constituição de Lecompton - no recém-criado Estado do Kansas, o que fez com que ele se tornasse impopular, principalmente no Norte.

Em 1858, Abraham Lincoln (republicano) e Stephen Douglas (democrata) se candidataram a uma vaga no Senado dos Estados Unidos pelo Estado de Illinois. A série de sete debates entre os candidatos ficou conhecida como 'os debates Lincoln-Douglas' e o principal assunto nas discussões foi a questão da escravidão, principalmente sua expansão nos novos territórios dos Estados Unidos.

Lincoln perde as eleições para o Senado, e sobre os novos rumos que o Partido Republicano tomaria depois de então, Binkley (1961, p.315) afirma: “a derrota de Frémont em 1856 e a de Lincoln contra Douglas em 1858 convenceram os líderes republicanos de que apenas o idealismo da Declaração de Independência não dava motivação suficiente para ganhar eleições". Assim, o partido toma medidas mais práticas, que serão refletidas na Plataforma da Convenção de 1860.

Na Plataforma de 1860, afirma-se que o curso da história nos últimos quatro anos exige mais do que nunca o triunfo pacífico e constitucional do Partido Republicano. A plataforma fala novamente sobre os direitos inalienáveis e os princípios da Declaração de Independência e da Constituição Federal e defendem que a União deve ser preservada. Dessa forma, afirma que nenhum membro republicano no Congresso proferiu 'ameaças de desunião', o que foi feito por membros democratas, e denunciam ameaças de secessão proferidas (REPUBLICAN NATIONAL CONVENTION, 1860). 
Na Plataforma também está indicada a defesa republicana pelo direito de cada Estado para controlar suas próprias instituições, há uma manifestação contrária à Constituição de Lecompton no Kansas e afirmam que é crime a invasão ilegal por forças armadas em qualquer Estado ou território. Além disso, os republicanos manifestam oposição contra mudanças nas leis de naturalização, e favoráveis à construção de uma estrada de ferro para o Oceano Pacífico - apontada como de grande interesse nacional (REPUBLICAN NATIONAL CONVENTION, 1860).

Dois trechos são essencialmente importantes na Plataforma do Partido Republicano de 1860. O primeiro diz respeito a existência da escravidão, considerada contrária ao direito de liberdade - é o item número 8 da Plataforma. Mais uma vez, os republicanos citam a $5^{\text {a emenda }}$ da Constituição Federal para dar embasamento, conforme pode-se constatar a seguir:

\begin{abstract}
Que a condição normal de todo o território dos Estados Unidos é o da liberdade: Que, como nossos pais Republicanos, quando aboliram a escravidão em todo o nosso território nacional, ordenou que "nenhuma pessoa deve ser privada da vida, liberdade ou propriedade sem o devido processo legal", torna-se nosso dever, pela legislação, sempre que essa legislação é necessária, para manter esta disposição da Constituição contra qualquer tentativa de violá-la; e nós negamos a autoridade do Congresso, de uma legislatura territorial, ou de qualquer indivíduo de dar existência legal à escravidão em qualquer território dos Estados Unidos. (REPUBLICAN NATIONAL CONVENTION, 1860, tradução elaborada pela autora)
\end{abstract}

O segundo trecho fala sobre as terras públicas, o que indica a relação entre os republicanos e os princípios do Solo Livre. O item é o número 13 da Plataforma, e pode ser conferido a seguir:

Que nós protestamos contra qualquer venda ou alienação a terceiros de terras públicas mantidas por colonos, e contra qualquer ponto de vista da política de herdade livre que diz respeito aos colonos como indigentes ou suplicantes de generosidade pública; e exigimos a aprovação pelo Congresso de uma medida para herdade completa e satisfatória, que já foi aprovada pela Câmara. (REPUBLICAN NATIONAL CONVENTION, 1860, tradução elaborada pela autora)

O Partido Democrata estava enfraquecido e dividido, então, por conta disso, não chegaram a um consenso para candidato à Presidência; foram lançados três postulantes em agremiações diferentes que nasceram da cisão desta sigla.

As plataformas dos Democratas (de Stephen Douglas) e dos chamados Democratas do Sul (de John Breckenridge) são bem parecidas, ambas se posicionam contra interferências do Congresso na execução da lei do escravo fugido, afirmando que são subversivas da Constituição. Além disso, consideram como um dever do Governo Federal a proteção do direito das pessoas e bens nos territórios. O Partido Democrata ainda afirma que a proteção deve ser 
ampla e completa, independente do cidadão ser nativo ou estrangeiro. Os dois partidos também se declaram favoráveis à aquisição da ilha de Cuba.

Os Democratas do Sul, além disso, dissertam sobre o direito de soberania e igualdade dos estados, conforme percebe-se no seguinte trecho:

\begin{abstract}
Que, quando os colonos em um território, que tenham uma população adequada, formarem uma Constituição de Estado, o direito à soberania começa, e sendo consumados pela admissão na União, eles estão em pé de igualdade com a população de outros Estados e o estado assim organizado deve ser admitido na União Federal, quer a sua Constituição proíba ou reconheça a instituição da escravidão. (SOUTHERN DEMOCRATIC NATIONAL CONVENTION, 1860, tradução elaborada pela autora).
\end{abstract}

O Partido da União Constitucional faz uma breve declaração em sua plataforma, reforçando o dever de não reconhecer nenhum princípio político que não seja a Constituição, a União dos Estados e o cumprimento das leis. A agremiação também se compromete a defender os princípios da liberdade e da segurança pública nacional, contra inimigos externos e internos.

Os republicanos lançam a candidatura de Abraham Lincoln para presidente. Com o Partido Democrata desmembrado, cada um dos três novos partidos lança uma candidatura. O resultado da eleição foi amplamente favorável a Lincoln, conforme pode-se atestar no mapa e na tabela a seguir:

Imagem 3 - Resultado das eleições de 1860

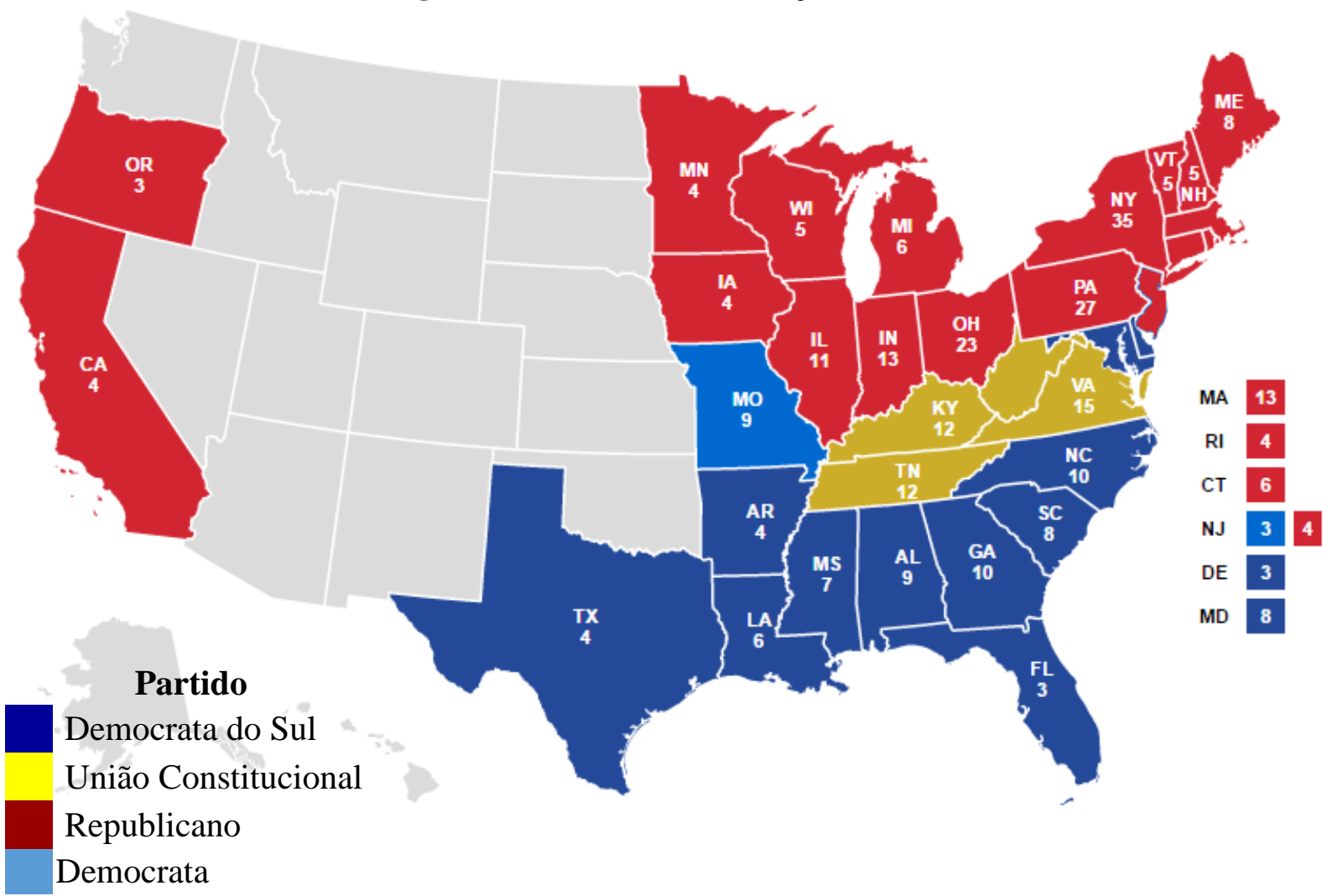

Fonte: 270 To Win (2016c). Tradução e adaptação pela autora. 
Tabela 3 - Resultado das eleições de 1860

\begin{tabular}{|c|c|c|c|c|c|c|}
\hline Candidato & Vice & \multicolumn{2}{|c|}{$\begin{array}{c}\text { Partido } \\
\text { Político }\end{array}$} & \multicolumn{2}{c|}{ Votos populares } & \multicolumn{2}{c|}{$\begin{array}{c}\text { Votos } \\
\text { eleitorais }\end{array}$} \\
\hline $\begin{array}{c}\text { Abraham } \\
\text { Lincoln }\end{array}$ & $\begin{array}{c}\text { Hannibal } \\
\text { Hamlin }\end{array}$ & Republicano & 1.865 .908 & $39,9 \%$ & 180 & $59,4 \%$ \\
\hline $\begin{array}{c}\text { John } \\
\text { Breckenridge }\end{array}$ & Joseph Lane & $\begin{array}{c}\text { Democrata do } \\
\text { Sul }\end{array}$ & 848.019 & $18,1 \%$ & 72 & $23,8 \%$ \\
\hline John Bell & $\begin{array}{c}\text { Edward } \\
\text { Everett }\end{array}$ & $\begin{array}{c}\text { União } \\
\text { Constitucional }\end{array}$ & 590.901 & $12,6 \%$ & 39 & $12,9 \%$ \\
\hline $\begin{array}{c}\text { Stephen } \\
\text { Douglas }\end{array}$ & $\begin{array}{c}\text { Herschel } \\
\text { Johnson }\end{array}$ & Democrata & 1.380 .202 & $29,5 \%$ & 12 & $4,0 \%$ \\
\hline \multicolumn{3}{|c|}{ Total } & 4.685 .461 & $100 \%$ & 303 & $100 \%$ \\
\hline
\end{tabular}

Fonte: The American Presidency Project (2016d). Tradução e adaptação pela autora.

A vitória de Lincoln, porém, não se deu apenas devido à desarticulação do Partido Democrata, conforme afirma Binkley (1961, p.322): "Lincoln, vencendo nos Estados livres, obteve uma vitória decisiva no colégio eleitoral, resultado que não teria mudado se os votos de seus três competidores tivessem ido para um único candidato". A eleição de Lincoln, então, estaria ligada a todo o contexto político e econômico da década de 1850, com as insatisfações da administração democrata e a crise econômica.

Assim, o mandato de Lincoln na presidência rompe com o ciclo de dominação do governo nacional pelos escravocratas e altera os paradigmas do sistema partidário norteamericano. A desagregação do Partido Democrata e, posteriormente, a Guerra de Secessão, com vitória do Norte, confirmam a preponderância do Partido Republicano na presidência em seu primeiro grande ciclo eleitoral, que perdura até 1896 (SCHLESINGER JR., 1992).

\subsection{Crise econômica de 1873}

No período pré-capitalista, as crises eram causadas por catástrofes naturais, epidemias ou guerras, ou seja, se configuravam como crises de subprodução e escassez de alimentos. A partir da segunda metade do século XVIII e primeira metade do século XIX, com a $1^{\mathrm{a}}$ Revolução Industrial, houve um período de transição, com crises mistas ou conjugadas. Havia a ocorrência de baixa produção agrícola, mas começou-se a perceber também uma superprodução industrial: os países começaram a produzir em grande escala, mas ainda não haviam expandido tanto seus mercados consumidores.

A teoria econômica em vigência no século XIX era o liberalismo, inspirado nas ideias de Adam Smith. De acordo com a doutrina, o capitalismo funcionava em ciclos, em que um período de apogeu era seguido de uma recessão, que se regulava e dava lugar a um novo período 
de crescimento econômico. Em momentos de recessão, não devia ser feita nenhuma intervenção, pois a autorregularão do mercado garantiria que o retorno do equilíbrio, como uma 'mão invisível'. Os Estados se regulavam de acordo com essa teoria, deixando o mercado fluir livremente (NOGUEIRA-MESSARI, 2005).

Na segunda metade do século XIX, começaram a se aprimorar as tecnologias de comunicação e transporte. O setor financeiro, então, passou a se integrar mundialmente e, dessa forma, a crise que se iniciou em 1873 foi impactante por ter gerado efeitos em escala global. Nos Estados Unidos, as ferrovias foram um elemento-chave para compreender o seu desenvolvimento econômico. A partir de 1860, a malha ferroviária cresceu vertiginosamente, chegando a cerca de 320 mil quilômetros de trilhos na virada do século XIX para o século XX, o que contribui para o crescimento de grandes empresas e conglomerados (KARNAL, 2007).

As corporações, então, começaram a formar monopólios e também se percebeu o aumento das aplicações nas bolsas de investimentos. Segundo Karnal (2007, p.154):

As depressões econômicas acabaram, curiosamente, por consolidar o poderio das
grandes empresas e corporações, expondo as desvantagens da competição acirrada
que se praticava. Entre 1869 e 1898 , estima-se que cerca de $13 \%$ da renda nacional
foi aplicada na expansão da indústria e esse grande investimento de capital espelha a
ascensão dos bancos de investimento, centralizados em Wall Street, Nova York.

Após a Guerra Civil, no período de reconstrução, os Estados Unidos vivenciaram um breve período de prosperidade, com aumento das exportações agrícolas, crescimento das ferrovias, desenvolvimento das comunicações e aumento do número de imigrantes. O mercado financeiro caracterizou-se por altas taxas de juros, incentivando a aplicação nas bolsas. Contudo, esse momento de alta foi abruptamente interrompido em setembro de 1873, com a supervalorização das ações ferroviárias e de construção. A empresa financeira Jay Cook \& Co. foi à falência e, em seguida, outras também acompanharam seu caminho (WELLS, 1937).

O pânico se espalhou e foi agravado com a quebra da bolsa de Viena que, quando atingiu a economia britânica, gerou uma crise em escala mundial. A depressão persistiu até o final da década, com altos índices de deflação ${ }^{12}$ observados nas principais economias globais. Houve uma pequena recuperação econômica entre 1880 e 1882, mas a queda de preços continuou até 1896 (WELLS, 1937).

A principal causa da crise foi o descontrole financeiro, conforme elucida Wells (1937, p.623, tradução elaborada pela autora):

${ }^{12}$ Queda generalizada dos preços. 
Em retrospecto, parece que as crises ocorreram em grande parte devido aos excessos financeiros que haviam caracterizado os cinco ou seis anos que precederam 1873. Os governos e indivíduos pegavam emprestado para financiar empresas de quase todos os tipos, especialmente de construção de ferrovias. Os Estados Unidos, Turquia, Egito e América do Sul foram fornecidos com fundos da Inglaterra, que emprestou mais de 1,5 bilhões de dólares no breve período de 1870 a 1874 [...].

Com relação à abordagem dos partidos, analisando as Plataformas de 1876, é perceptivo o comportamento acusatório do Partido Democrata na questão, ressaltando diversas vezes a necessidade de reforma do governo federal: "reforma é necessária para estabelecer uma moeda sólida, restaurar o crédito público e manter a honra nacional" (DEMOCRATIC NATIONAL CONVENTION, 1876, tradução elaborada pela autora). No tocante econômico, os democratas denunciam, especialmente, a "imbecilidade financeira" (DEMOCRATIC NATIONAL CONVENTION, 1876, tradução elaborada pela autora), a incapacidade de avançar em direção a uma reconstrução em onze anos de administração e altas tarifas protecionistas.

Exigimos um sistema jurídico de preparação pelas economias públicas, por reduções oficiais e por financiamento prudente, que deve permitir à nação em breve assegurar ao mundo inteiro de sua perfeita capacidade e perfeita disponibilidade de atender a qualquer de seus compromissos, ao chamado, o credor tem direito a pagamento. (DEMOCRATIC NATIONAL CONVENTION, 1876, tradução elaborada pela autora)

A solução para a crise, para os democratas, seria a elaboração de um sistema de controle financeiro oficial com vistas a garantir o pagamento dos empréstimos. A plataforma toda fala em mudança de governo e de partido, com a crise tendo acentuado a ineficiência da administração republicana. Há uma grande presença de tópicos econômicos, no entanto, o enfoque é ressaltar as falhas do governo de Grant em minimizar os efeitos da depressão (DEMOCRATIC NATIONAL CONVENTION, 1876). Na Plataforma do Partido Republicano, em contrapartida, não há muito destaque para as questões financeiras. O item 4 do programa é o que há maior referência ao assunto, conforme abaixo:

No primeiro ato de Congresso, assinado pelo presidente Grant, o governo nacional assumiu-se de modo a remover qualquer dúvida de sua finalidade de cumprir todas as obrigações para com os credores públicos [...]. Prosperidade comercial, moral pública, e o crédito nacional demandam que essa promessa seja cumprida por um contínuo e processo constante de pagamento em espécie. (REPUBLICAN NATIONAL CONVENTION, 1876, tradução elaborada pela autora)

As eleições desse ano foram extremamente acirradas e controversas; o candidato republicano era Rutherford Hayes e o democrata, Samuel Tilden. Sinaliza-se, observando ambas as plataformas e o posterior resultado do escrutínio, que a crise econômica teria gerado impactos na hegemonia do Partido Republicano, sólida desde a vitória de Lincoln e a Guerra de Secessão. 
A incapacidade do governo de dar respostas satisfatórias à depressão gerou descontentamentos da população, o que se refletiu nos votos populares recebidos por Tilden, que venceu o adversário republicano por 4.288.191 a 4.033.497. Porém, no Colégio Eleitoral, Hayes venceu com a diferença de um voto, por 185 a 184. Os democratas contestaram o resultado e foi criada uma Comissão Eleitoral para atestar a validade das eleições. No entanto, permaneceu a vitória de Hayes.

Imagem 4 - Resultado das eleições de 1876

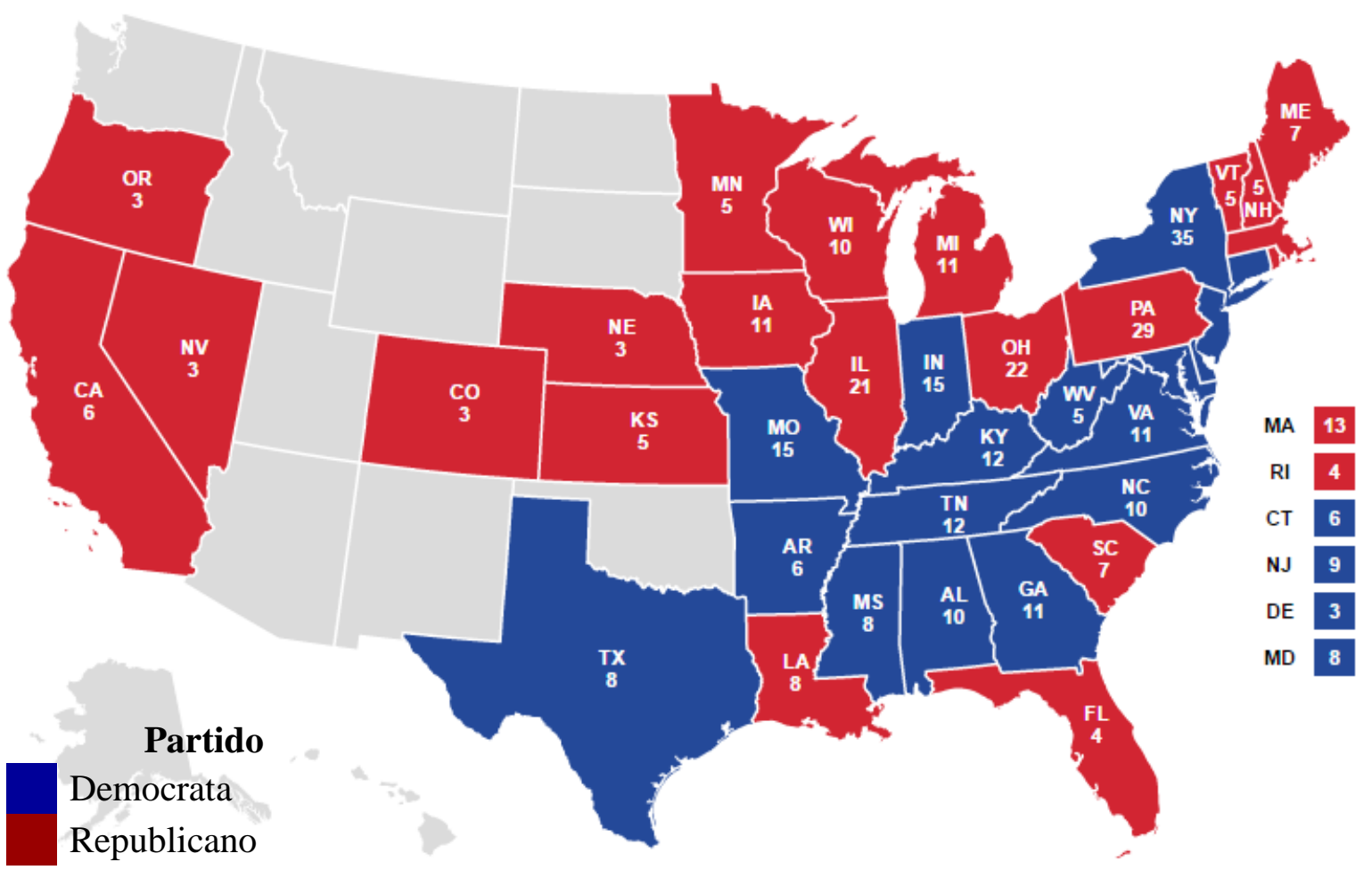

Fonte: 270 To Win (2016d). Tradução e adaptação pela autora.

Tabela 4 - Resultado das eleições de 1876

\begin{tabular}{|c|c|c|c|c|c|c|}
\hline Candidato & Vice & $\begin{array}{l}\text { Partido } \\
\text { Político }\end{array}$ & \multicolumn{2}{|c|}{ Votos populares } & \multicolumn{2}{|c|}{$\begin{array}{c}\text { Votos } \\
\text { eleitorais }\end{array}$} \\
\hline $\begin{array}{c}\text { Rutherford B. } \\
\text { Hayes }\end{array}$ & $\begin{array}{l}\text { William } \\
\text { Wheeler }\end{array}$ & Republicano & 4.033 .497 & $48 \%$ & 185 & $50,1 \%$ \\
\hline Samuel Tilden & $\begin{array}{c}\text { Thomas } \\
\text { Hendricks }\end{array}$ & Democrata & 4.288.191 & $51 \%$ & 184 & $49,9 \%$ \\
\hline \multicolumn{3}{|c|}{ Total } & 8.411 .618 & $100 \%$ & 369 & $100 \%$ \\
\hline
\end{tabular}

Fonte: The American Presidency Project (2016e). Tradução e adaptação pela autora.

A análise apenas dos números não é suficiente para compreender os impactos. Avaliar as plataformas e a condução do processo eleitoral permite perceber um descontentamento com a forma de conduzir a política do Partido Republicano. Sendo assim, a preponderância da 
agremiação no poder durante praticamente toda a segunda metade do século XIX não é completamente inquestionada, tendo sido alvo de críticas que se estenderam aos votos populares. Contudo, o Partido Democrata, com Grover Cleve1and nos mandatos de 1883-1886 e 1893-1897 também recebeu críticas pela incapacidade de gerenciar a crise, que só obteve seu fim com o crescimento da colonização imperialista. A principal diferença dos dois partidos é em relação às tarifas protecionistas, que os republicanos defendem, enquanto que os democratas condenam. Essa divergência se perpetuará também ao longo da primeira metade do século XX, conforme será abordado nos próximos capítulos. 


\section{CAPÍTULO 2}

\subsection{Era Progressista}

No início do século XX, ocorreu nos Estados Unidos um movimento chamado de 'Era Progressista'. De acordo com Milkis (2012), tal período consistiu em um prelúdio do New Deal e, ademais, contribuiu para a reformulação de sentido e prática do conceito de autogoverno. $\mathrm{O}$ autor acredita que eleições e partidos moldam a democracia norte-americana. Tal pressuposto pode ser comprovado ao perceber diversas mudanças do curso da política e das concepções das agremiações a partir desse período. A cisão do Partido Republicano em 1912 pode ser considerada como simbólica para o rumo com que as decisões serão tomadas a partir de então.

\subsubsection{As eleições de 1912 e as transformações no sistema eleitoral}

As eleições de 1912 foram transformativas e consideradas como um ponto crítico na democracia dos Estados Unidos (MILKIS, 2012) devido a algumas mudanças nas regras eleitorais. Na primeira década do século XX, eleições primárias eram feitas para escolher delegados para a Convenção Nacional em alguns estados. Em 1912, foi a primeira vez em que um candidato presidencial tenta ser nomeado via primárias populares, Theodore Roosevelt, pelo Partido Republicano (KALB, 2016). Outra importante mudança de regras eleitorais foi o estabelecimento de eleições diretas para Senadores.

O objetivo da introdução das primárias como método principal era de evitar o controle excessivo dos grandes chefes dos partidos na escolha dos candidatos à presidência. Em 1912, o candidato indicado pelo Partido Republicano era William Howard Taft, pleiteando a reeleição. Os outros pré-candidatos eram o Senador Robert La Follette de Wisconsin, líder da Liga Nacional Progressista (segmento criado dentro do partido, em 1911) e Theodore Roosevelt, que já havia sido presidente dos Estados Unidos por dois mandatos (KALB, 2016).

Roosevelt, nas primárias populares, conseguiu vitória em nove dos doze estados que adotaram a regra, enquanto que Taft somente obteve sucesso em um ${ }^{13}$. No entanto, na Convenção Nacional, apenas $42 \%$ dos delegados haviam sido selecionados pelas primárias, enquanto que o restante foi escolhido pelos líderes do partido, apoiadores de Taft. Dessa forma, o resultado da nomeação presidencial foi desfavorável a Roosevelt, com vitória de Taft por 566 votos a 466 (THE NEW YORK TIMES, 1912).

\footnotetext{
${ }^{13}$ Roosevelt venceu em: Illinois, Pensilvânia, Nebraska, Oregon, Maryland, Califórnia, Ohio, New Jersey e Dakota do Sul, enquanto que Taft venceu em Massachusetts e La Follette, na Dakota do Norte e Wisconsin (KALB, 2016).
} 
Em decorrência disso, houve uma dissidência no Partido Republicano e fundação do Partido Progressista, com objetivo de endossar a candidatura de Roosevelt. Chester (1977) avalia a administração de Taft e percebe conquistas na linha progressista de Roosevelt, apesar da orientação mais conservadora. Dobrou-se o número de processos antitruste, com destaque nos processos contra a Standard Oil e a American Tobacco Company que tramitaram na Suprema Corte em 1911. No entanto, Taft ainda tinha traços conservadores, não levando em consideração os interesses dos produtores de cereais, por exemplo. Segundo Binkley (1961), essa camada social era essencial no jogo político desde a ratificação da Constituição. O Partido Progressista foi fundado com peso nesses produtores de cereais e laticínios do Norte conseguindo, dessa forma, apoio e votos. Ademais, no período do movimento progressista, os trabalhadores industriais, normalmente republicanos, estavam aderindo a programas mais favoráveis à democracia social, estando o conservantismo em desfavor.

O Partido Progressista também era chamado de 'Bull Moose Party', Partido do Alce, e foi pioneiro em novas formas de política explicitamente definidas como modernas. $\mathrm{O}$ momento era favorável e o grupo consolidou-se como vanguarda do movimento progressista. $\mathrm{O}$ crescimento do poder de influência das grandes corporações era um assunto em pauta bastante debatido, no sentido que o federalismo parecia corrompido por tais conglomerados, devendo, portanto, ser combatidos (MILKIS, 2012).

O Partido Democrata adotou seu próprio candidato com viés progressista, Woodrow Wilson, que havia sido reitor da Universidade de Princeton. Wilson era progressista, contudo, mais moderado do que Roosevelt em seu reformismo. O postulante democrata tinha a ideia de aumentar a participação global dos EUA, com uma justificativa considerada messiânica, através da qual os Estados Unidos tinham a obrigação moral de propagar seus princípios pelo mundo. A paz e a democracia estariam intrinsecamente ligadas; os Estados deveriam ser julgados com os mesmos critérios éticos dos indivíduos; e o interesse nacional deveria ser fiel a um sistema universal de leis (KISSINGER, 1997).

Esses princípios não eram inéditos, advinham de meados do século XIX com o Destino Manifesto. Essa doutrina expressava a convicção de que os Estados Unidos teria sido o povo escolhido por Deus e, por isso, estariam aptos a levar aquele modelo de civilização para os demais povos. O expansionismo americano se manifestou, no século XIX, sobretudo nas Américas, estando fortemente ligado à Doutrina Monroe. Até a virada do século XX, então, os Estados Unidos se propunha basicamente a realizar o Destino Manifesto, se concentrando no continente americano e permanecendo afastada dos assuntos europeus (KISSINGER, 1997). Na plataforma de 1912, há menções de apoio à Doutrina Monroe, conforme percebe-se a seguir, 
se referindo à criação, pela liderança democrata na Câmara dos Deputados, de um Conselho Nacional de Defesa:

O partido que proclamou e sempre aplicou a Doutrina Monroe, e foi patrocinador da
nova marinha, vai continuar fielmente a observar os requisitos constitucionais para
prover e manter uma marinha bem proporcional, suficiente para defender as políticas
americanas, proteger nossos cidadãos e dar suporte à honra e à dignidade da nação.
(DEMOCRATIC NATIONAL CONVENTION, 1912, tradução elaborada pela
autora)

No tocante aos aspectos econômicos abordados pelos democratas na Plataforma de 1912, o mais relevante era a reforma tarifária. O partido critica as altas tarifas aplicadas pelo governo republicano e aponta que estas seriam a principal causa da distribuição desigual de riqueza no país. Ademais, são ressaltadas as conquistas democratas no Congresso, como leis para diminuir os gastos e extravagâncias do governo, reduzindo suas despesas anuais, a limitação do horário de trabalho para oito horas diárias no serviço público, as eleições diretas para o Senado e a admissão do Arizona e do Novo México como Estados soberanos na federação (DEMOCRATIC NATIONAL CONVENTION, 1912).

Os democratas também se posicionam favoráveis à supervisão e regulação de empresas de ferrovias, companhias expressas, telégrafos e linhas telefônicas, de acordo com o seguinte trecho:

Para essa finalidade nós recomendamos a avaliação de ferrovias, companhias expressas, telégrafos e linhas telefônicas pela Comissão Interestatal de Comércio, tal avaliação para ter considerações sobre o valor físico da propriedade, o custo original, o custo de reprodução e qualquer elemento de valor que vá render uma avaliação imparcial e justa. (DEMOCRATIC NATIONAL CONVENTION, 1912, tradução elaborada pela autora)

Com esse excerto, percebe-se o objetivo do Partido Democrata na tentativa de regulamentação das especulações. É necessário avaliar apropriadamente o valor das empresas; dessa forma, ao inseri-las no mercado financeiro, há um real parâmetro de rendimentos, possivelmente evitando eventuais bolhas financeiras. Na segunda metade do século XIX, conforme já abordado, o principal ativo em negociação nas bolsas de ações foram as ferrovias. O Pânico de 1857 ocorreu justamente por conta de alta especulação no mercado de ferrovias e terras; a Ohio Life Insurance and Trust Company, banco de investimentos, foi à falência e os investidores perderam todos os seus fundos. Isto posto, a proposta democrata para que esse tipo de crise não ocorra é a regulamentação do valor das ações de empresas nesses setores.

Acerca da legislação bancária, o Partido Democrata se posiciona contrário ao estabelecimento de um banco central, além da defesa de uma revisão sistemática das leis que concernem os bancos. Segundo a plataforma, a existência de bancos é condicionada à 
acomodação do público, e não para o controle do negócio. Sendo assim, a reforma seria necessária para prevenir depressões e consequentemente o desemprego (DEMOCRATIC NATIONAL CONVENTION, 1912).

A Plataforma do Partido Republicano, em contraposição, ressalta os avanços da administração de Taft e se posiciona favorável às tarifas protecionistas criticadas pelos democratas. Em convergência ao Partido Democrata, manifesta sua oposição a privilégios especiais concedidos a empresas e a monopólios. Com isso, aponta a Lei Comercial Interestatal de 1887 e a Lei Antitruste de 1890, afirmando que há necessidade de promulgação de legislação complementar, definindo a ocorrência de truste como infração criminal (REPUBLICAN NATIONAL CONVENTION, 1912).

A defesa da proibição dos monopólios é sustentada pela crença de que o livre mercado é a melhor solução para garantir crescimento econômico. No trecho citado a seguir, essa ideia é apontada de forma bastante esclarecedora: "O direito de todo homem de adquirir commodities, e particularmente as necessidades da vida, em um mercado aberto não influenciado pela manipulação de truste ou combinação, deve ser preservado" (REPUBLICAN NATIONAL CONVENTION, 1912, tradução elaborada pela autora).

No tocante à tarifa protecionista, os republicanos ressaltam:

A política tarifária Republicana tem sido de grande benefício para o país, desenvolvendo nossos recursos, diversificando nossas indústrias e protegendo nossos trabalhadores contra competição de trabalhadores mais baratos no exterior, assim estabelecendo para nossos assalariados o padrão de vida americano. (REPUBLICAN NATIONAL CONVENTION, 1912, tradução elaborada pela autora)

Assim, defendem que as tarifas protecionistas asseguram as indústrias e os trabalhadores através do incentivo aos produtos nacionais. Ademais, a plataforma também destaca que o aumento do custo de vida não ocorre em decorrência da política tarifária, sendo que no mundo todo isso pode ser atestado. Para resolver essa questão, os republicanos se comprometem em realizar uma investigação das causas desse aumento, para então agir na remoção dos abusos, quando os motivos forem conhecidos (REPUBLICAN NATIONAL CONVENTION, 1912).

Os republicanos, tais como os democratas, também falam sobre reformas nas instituições bancárias para prevenir novas ocorrências de pânicos monetários e distúrbios financeiros. Reforçam a necessidade de revisão dos requisitos das condições monetárias. No entanto, não abordam a questão da instituição de um banco central e defendem a promoção da prosperidade dos negócios e do bem-estar do trabalho. Através do crescimento das empresas, é possível estabelecer um constante emprego. Por fim, o partido reforça o esforço da administração republicana de assegurar maior economia e maior eficiência na condução dos 
negócios governamentais, ressalta a prosperidade econômica adquirida com Taft e a legislação construtiva aprovada em consonância com o Congresso republicano (REPUBLICAN NATIONAL CONVENTION, 1912).

O Partido Progressista, por sua vez, faz um ataque sistêmico aos partidos tradicionais. Segundo Milkis (2012), a propaganda fez bastante uso de mídias de massa, como jornais e filmes e usou esses instrumentos para criticar a posição política das duas principais agremiações.

Os progressistas iniciam a sua plataforma eleitoral apontando a necessidade de formação de um novo partido, considerando "o período de graves problemas nacionais" (PROGRESSIVE NATIONAL CONVENTION, 1912, tradução elaborada pela autora). Se consideram, nesse sentido, portadores do senso de justiça para o povo norte-americano, defendendo a "a manutenção do governo do povo, pelo povo e para o povo" (PROGRESSIVE NATIONAL CONVENTION, 1912, tradução elaborada pela autora), de acordo com o que foi proposto pelos Pais Fundadores. Com isso, faz-se a crítica de que os democratas e republicanos abandonaram esse princípio ao longo dos anos e que então seria o dever de um novo partido restaurá-los. O fio condutor inicial do documento é, portanto, reforçar o objetivo do governo de servir ao bemestar da população (PROGRESSIVE NATIONAL CONVENTION, 1912).

Em relação ao alto custo de vida, os progressistas acreditam que em parte a causa é mundial e em parte é local, e também apontam causalidade dividida entre naturais e artificiais. Para eliminar as causas artificiais, o partido defende a necessidade de uma efetiva supervisão governamental através da revisão da política tarifária. Ademais, aponta que a prosperidade do desenvolvimento econômico deve abarcar toda a população, e não apenas classes específicas. Isto posto, deve haver desenvolvimento também do crédito agrícola, para equiparar as pessoas do campo às das cidades (PROGRESSIVE NATIONAL CONVENTION, 1912).

Dois fatores são bastante pormenorizados na plataforma, no tocante às questões econômicas: o problema da concentração de corporações e as tarifas protecionistas. No primeiro assunto, o Partido Progressista reconhece a inevitabilidade da formação de concentração para eficiência dos negócios nacional e internacional, mas afirma que deve haver uma atenção em relação ao abuso de poder no sistema corporativo. Nos monopólios, há, segundo a plataforma, “concorrência desleal e privilégios injustos" (PROGRESSIVE NATIONAL CONVENTION, 1912, tradução elaborada pela autora) que devem ser combatidos. A solução seria uma forte regulação governamental dessas corporações interestatais. Assim, os progressistas apontam a importância do poder da Comissão de Comércio Interestatal e demandam a abolição do 
Tribunal de Comércio, para que este não restrinja a atuação da Comissão (PROGRESSIVE NATIONAL CONVENTION, 1912).

Sobre o sistema de tarifas protecionistas, os progressistas se encontram em um posicionamento intermediário entre os dos partidos Democrata e Republicano. Entendem a importância da tarifa de proteção, mas são enfáticos na questão de que ela deve ser benéfica ao trabalhador. As condições de competição entre os Estados Unidos e os outros países devem ser equalizadas no sentido de manter o padrão de vida do povo norte-americano, além de sempre ter o consumidor como central na sua definição. Dessa forma, ressaltam que o sistema protecionista vigente deve ser revisado, estabelecendo-se uma comissão não-partidária e técnica para avalia-lo. São contrários à Lei Payne-Aldrich, republicana, mas também não consideram adequada visão democrata de destruição do sistema que, segundo a plataforma progressista, ocasionará em "desastre industrial e comercial generalizado" (PROGRESSIVE NATIONAL CONVENTION, 1912, tradução elaborada pela autora).

Por fim, em relação ao sistema nacional monetário, afirmam que é necessário efetuar uma revisão da legislação vigente. No método em curso, as notas eram emitidas através de agências privadas, o que é impensável para o Partido Progressista, pois é prejudicial e carece de imparcialidade. Segundo seus princípios, a emissão de moeda é uma função do governo e assim deve ser seu controle, visando o interesse nacional, e não atendendo a conveniências particulares, especialmente de Wall Street (PROGRESSIVE NATIONAL CONVENTION, 1912). Esse pensamento é interessante, uma vez que a administração monetária é um importante instrumento de controle da inflação e outros distúrbios econômicos. Quando a plataforma foi lançada, não havia um Banco Central nos Estados Unidos (foi estabelecido em 1913) e todo o sistema financeiro era gerenciado por bancos privados e regionais. Ademais, o pressuposto era de que o equilíbrio monetário era atingido naturalmente, através da interação de oferta e demanda no mercado, sendo que a intervenção governamental era vista como prejudicial. Esses paradigmas cairão com a depressão, após a quebra de 1929, mas é significativo perceber como as ideias começam a ser abordadas.

Wilson, do Partido Democrata, venceu as eleições, mas com um resultado apertado no escrutínio popular, como se pode verificar na tabela 5. De acordo com Bailey (1968), a vitória foi assegurada por causa da divisão dentro do Partido Republicano. O autor esclarece:

Se os Republicanos tivessem se unido por trás de um candidato, e tivessem permanecido unidos, eles provavelmente teriam ganhado. Se não pudessem se reunificar, perderiam novamente. Há um antigo axioma na política em que o partido no poder é derrotado: ele se divide em facções e assegura a própria derrota. (BAILEY, 1968, p.95, tradução elaborada pela autora) 
De fato, foi o que ocorreu, em parte com as mesmas razões das eleições de 1860, com a vitória de Lincoln do Partido Republicano. Bailey (1968) ainda afirma que esse momento representou uma mudança de identidade no partido, que começa a se tornar mais conservador. O movimento progressista que Roosevelt havia implementado se dissipa, com a agenda reformista se perdendo.

Imagem 5 - Resultado das eleições de 1912

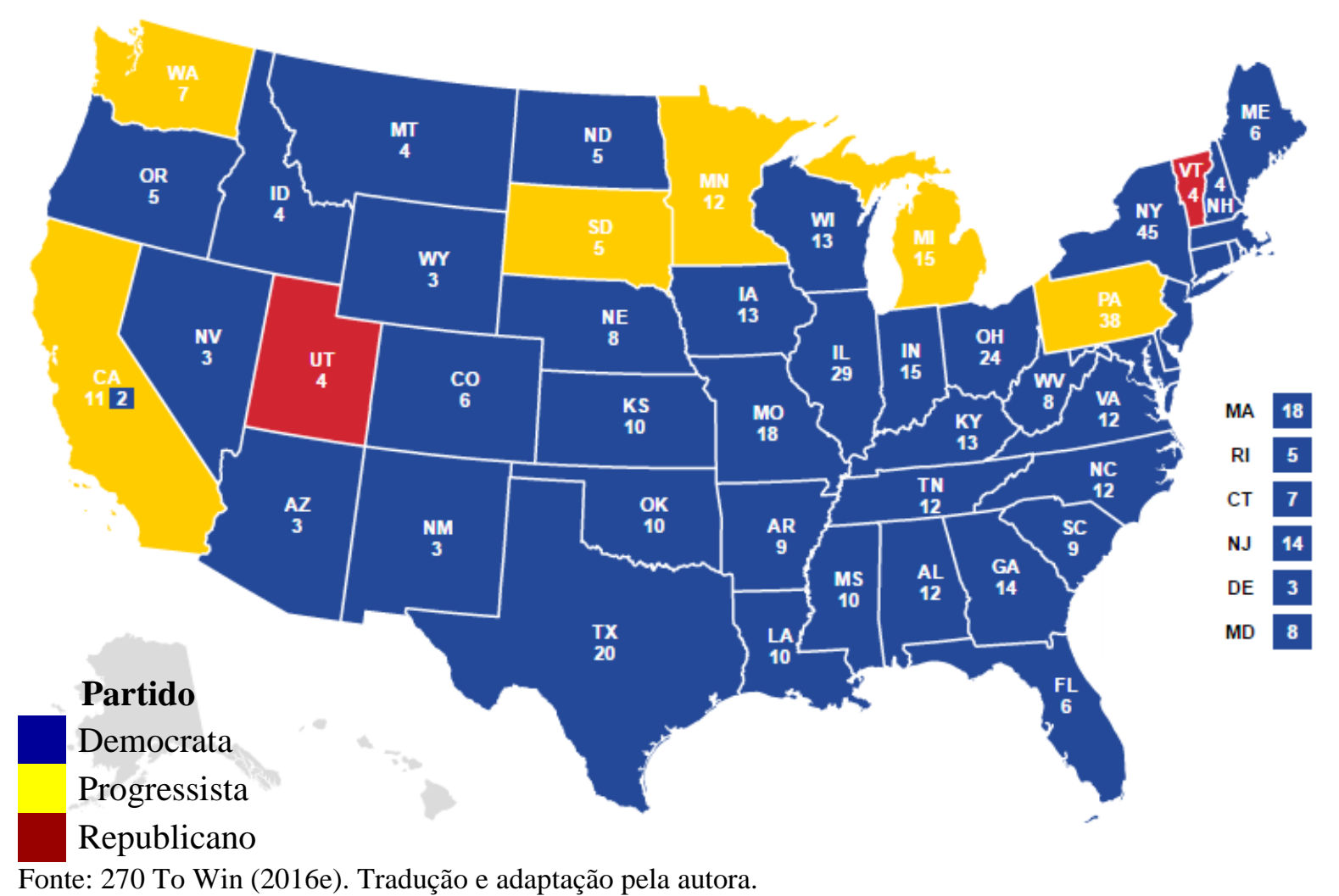

Tabela 5 - Resultado das eleições de 1912

\begin{tabular}{|c|c|c|c|c|c|c|}
\hline Candidato & Vice & \multicolumn{2}{|c|}{$\begin{array}{c}\text { Partido } \\
\text { Político }\end{array}$} & \multicolumn{2}{|c|}{ Votos populares } & \multicolumn{2}{|c|}{$\begin{array}{c}\text { Votos } \\
\text { eleitorais }\end{array}$} \\
\hline $\begin{array}{c}\text { Woodrow } \\
\text { Wilson }\end{array}$ & $\begin{array}{c}\text { Thomas } \\
\text { Marshall }\end{array}$ & Democrata & 6.294 .327 & $41,8 \%$ & 435 & $81,9 \%$ \\
\hline $\begin{array}{c}\text { Theodore } \\
\text { Roosevelt }\end{array}$ & $\begin{array}{c}\text { Hiram } \\
\text { Johnson }\end{array}$ & Progressista & 4.120 .207 & $27,4 \%$ & 88 & $16,6 \%$ \\
\hline William Taft & $\begin{array}{c}\text { Nicholas } \\
\text { Butler }\end{array}$ & Republicano & 3.486 .343 & $23,2 \%$ & 8 & $1,5 \%$ \\
\hline Eugene Debs & Emil Seidel & Socialista & 900.370 & $6,0 \%$ & 0 & $0,0 \%$ \\
\hline \multicolumn{2}{|c|}{ Total } & & 15.043 .030 & $100 \%$ & 531 & $100 \%$ \\
\hline
\end{tabular}

Fonte: The American Presidency Project (2016e). Tradução e adaptação pela autora. 


\subsubsection{6: segunda interrupção democrata}

Em 1916, percebe-se uma reformulação do sistema partidário, após a desarticulação do Partido Progressista. Dos dissidentes desta terceira via, poucos retornam ao Partido Republicano, que havia dado origem à agremiação; sendo que boa parcela desloca seu apoio a Wilson. Grande parte do programa de trabalho progressista foi incorporado ao Partido Democrata, com reforma tarifária, bancária e Leis Antitruste. Ademais, o atual presidente também angaria apoio popular devido à política de não entrar na Grande Guerra ( "he kept us out of war" - slogan: ele nos manteve fora da guerra). A Europa entrou em conflito em 1914, mas no início, os EUA se mantiveram afastados, de acordo com a sua tendência de política externa: isolacionista, entendida como um distanciamento de assuntos da Europa ${ }^{14}$.

Na Plataforma do Partido Democrata de 1916, são enaltecidas as políticas de Wilson, tanto no âmbito interno quanto externo. Após um longo período de hegemonia republicana, os democratas reformularam o sistema bancário e monetário, com a justificativa de que tais modelos vigentes se encontravam defasados. A Lei que criou o Federal Reserve, de acordo com a plataforma, possibilitou prevenções de pânicos monetários, além de propiciar crédito à indústria. Ademais, afirmam que foi benéfica a criação da Comissão de Comércio Federal, com objetivo de acabar com os monopólios e assegurar uma justa competitividade (DEMOCRATIC NATIONAL CONVENTION, 1916). Nesse sentido, também foram feitos ajustes na política fiscal, conforme necessidade apontada em plataformas anteriores.

Os democratas, além disso, defendiam a continuidade do período de prosperidade, salientando que pretendem providenciar uma Comissão Tarifária não partidária para analisar os fatos econômicos alterados pela guerra. O conflito envolveu diretamente boa parte das potências industriais tendo, sem dúvida, acometido o mundo todo, gerando alterações financeiras e industriais. Reiteram também a parcimônia no que diz respeito à economia estatal; deve haver responsabilidade nas despesas públicas como início de um processo de construção de um sistema orçamentário (DEMOCRATIC NATIONAL CONVENTION, 1916).

O principal eixo seguido pela Plataforma do Partido Republicano é a crítica ao mandato democrata de Wilson, especialmente no âmbito de sua atuação na Grande Guerra, conforme atesta-se no enxerto a seguir:

\footnotetext{
${ }^{14}$ Essa política era parte da Doutrina Monroe, anunciada pelo presidente James Monroe em 2 de dezembro de 1823, que oficializava a separação dos Estados Unidos e Europa, sendo que não haveria envolvimento americano em disputas europeias, assim como os europeus não influenciariam nos assuntos de interesses estadunidenses (KISSINGER, 1997).
} 
A atual Administração tem destruído nossa influência no exterior e nos humilharam aos nossos próprios olhos. O Partido Republicano acredita que uma política externa firme, consistente e corajosa, sempre mantida pelos Presidentes Republicanos de acordo com tradições Americanas é a melhor, pois é o único caminho verdadeiro para preservar nossa paz e restaurar-nos ao nosso lugar de direito entre as nações. (REPUBLICAN NATIONAL CONVENTION, 1916, tradução elaborada pela autora)

Na plataforma, após a crítica, é feita a defesa da Doutrina Monroe e apontado posicionamento favorável à continuidade das políticas republicanas de maior proximidade com os países na América Latina, nos âmbitos comercial, financeiro e social. Ademais, adicionalmente à desaprovação com relação à política externa democrata, os republicanos são contrários à Lei Underwood, de $1913^{15}$, pois teria privado aos produtores significativos ganhos (REPUBLICAN NATIONAL CONVENTION, 1916). Assim como na plataforma de 1912, as posições com relação à política tarifária são divergentes entre os dois partidos.

Os republicanos também apontam a continuidade do aumento no custo de vida, que não se reduziu com a diminuição das tarifas, conforme havia sido defendido pelos democratas. Além disso, acusam a administração vigente de limitar os negócios, sendo favoráveis ao incentivo às empresas e ao avanço em prol do interesse nacional. Por fim, há na plataforma acusações acerca do aumento dos gastos do governo nacional. Nesse sentido, o Partido Republicano sugere a necessidade do estabelecimento de um sistema de orçamento para realizar uma reforma nas finanças nacionais (REPUBLICAN NATIONAL CONVENTION, 1916).

A agremiação havia começado a se recuperar do choque das eleições de 1912. O escrutínio de 1916 foi altamente concorrido, com diferença de votos bem pequena entre os candidatos das duas maiores agremiações. Woodrow Wilson concorreu à reeleição contra Charles Hughes, do Partido Republicano. O candidato democrata foi vencedor, especialmente devido à sua popularidade nas questões de política externa e afastamento da guerra ${ }^{16}$. Ademais, conseguiu grande número de votos das mulheres, que podiam votar em alguns Estados do Oeste. O resultado, porém, foi apertado, tanto nos votos populares quanto nos eleitorais; até o último instante das apurações não era certo qual seria o próximo presidente, com momentos em que se acreditava que Hughes sairia vencedor (CHESTER, 1977). Os números podem ser conferidos no mapa e na tabela a seguir:

\footnotetext{
15 A Lei da Receita, que ficou conhecida como Lei Underwood por ter sido patrocinada pelo Deputado Oscar Underwood, ratificou a $16^{\mathrm{a}}$ Emenda e abaixou as taxas tarifárias básicas de $40 \%$ para $25 \%$ (HOUSE OF REPRESENTATIVES, 1913).

${ }^{16}$ O presidente conseguiu certa vantagem política com o slogan “he kept us out of war" (CHESTER, 1977).
} 
Imagem 6 - Resultado das eleições de 1916

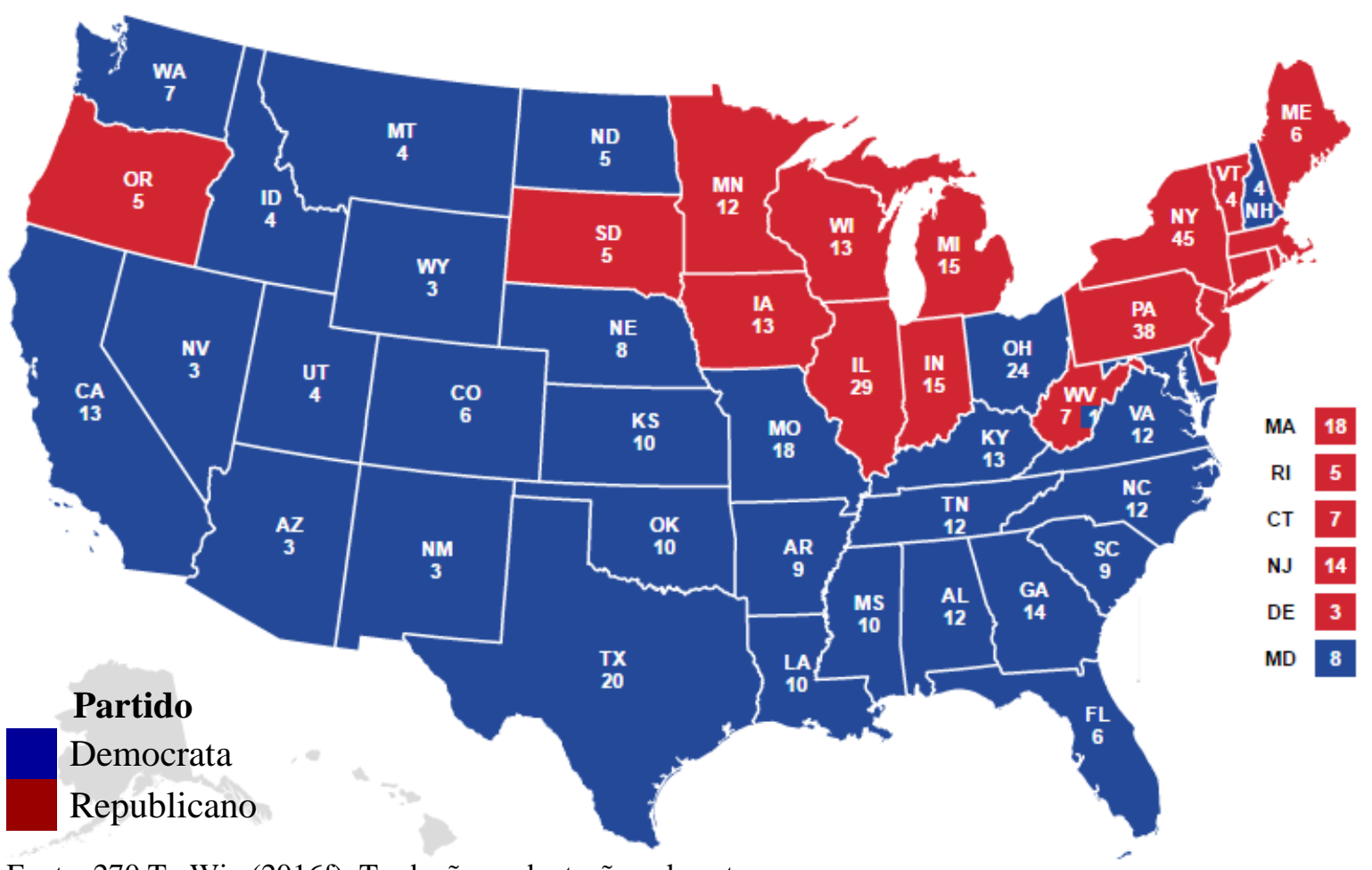

Fonte: 270 To Win (2016f). Tradução e adaptação pela autora.

Tabela 6 - Resultado das eleições de 1916

\begin{tabular}{|c|c|c|c|c|c|c|}
\hline Candidato & Vice & $\begin{array}{l}\text { Partido } \\
\text { Político }\end{array}$ & \multicolumn{2}{|c|}{ Votos populares } & \multicolumn{2}{|c|}{$\begin{array}{c}\text { Votos } \\
\text { eleitorais }\end{array}$} \\
\hline $\begin{array}{l}\text { Woodrow } \\
\text { Wilson }\end{array}$ & $\begin{array}{l}\text { Thomas } \\
\text { Marshall }\end{array}$ & Democrata & 9.126 .063 & $49,25 \%$ & 277 & $52,2 \%$ \\
\hline Charles Hughes & $\begin{array}{c}\text { Charles } \\
\text { Fairbanks }\end{array}$ & Republicano & 8.547 .030 & $46,11 \%$ & 254 & $47,8 \%$ \\
\hline \multicolumn{3}{|c|}{ Total } & 18.535 .445 & $100 \%$ & 531 & $100 \%$ \\
\hline
\end{tabular}

Fonte: The American Presidency Project (2016g). Tradução e adaptação pela autora.

Binkley (1961) analisa que desde a saída de Roosevelt, os republicanos não tiveram nenhum líder nacional com força suficiente para agregar diferentes grupos. O partido nasceu de um conjugado de vários segmentos sociais, porém, neste período, após a cisão de 1912, enfrentava a dificuldade de coesão nacional. Contudo, após o segundo mandato de Wilson, retomam a hegemonia interrompida, mantendo-se no poder durante toda a década de 1920, devido ao cenário altamente favorável economicamente dos Estados Unidos.

\subsection{Década de 1920 - Euforia econômica}

Após a Grande Guerra, a economia norte-americana passou por um período produção em alta, com preços estáveis e redução do índice de desemprego. Nesse momento, é possível 
analisar uma dicotomia entre o modelo americano e o europeu. Arrighi (2012) afirma que os Estados Unidos se equipararam à Inglaterra na produção, mas não a substituíram na regulação mundial das finanças. O autor afirma, ainda, que as instituições norte-americanas eram ineficientes e incapazes de administrar as finanças mundiais. A Reserva Federal (Federal Reserve, o Banco Central Americano) tinha sido recém-fundada (em 1913), mas ainda estava muito mal articulada, atuando precariamente nos assuntos internos e não sendo capaz de se comprometer com assuntos financeiros mundiais. Esses problemas nas instituições financeiras se refletiram posteriormente, no final da década de 1920, com a incapacidade de lidar com o boom especulativo e a quebra da bolha financeira.

Mesmo com limitações no setor bancário, a década de 1920 foi chamada de período da 'Grande Transformação' na economia norte-americana, tendo se centrado principalmente em três pilares básicos: a imigração, a produção em massa (de bens de consumo duráveis, em especial, de automóveis) e a importância dos salários na formação da demanda (LIMONCIC; MARTINHO, 2009). A combinação desses três elementos culminou na grande expansão da economia americana, que teve seu ápice no final da década de 1920. Esses três fatores estão intrinsecamente relacionados. A imigração colaborou para a o crescimento do setor industrial, e consequentemente aumentou a porcentagem da população vivendo nas zonas urbanas: em 1930, 56\% dos americanos moravam nas cidades, aumento significativo em relação a 1900, com 39\% de população urbana (LIMONCIC; MARTINHO, 2009). A produção em massa de bens duráveis de consumo foi proporcionada por este aumento populacional nos centros industriais, e a mão-de-obra imigrante teve essencial importância na implantação das novas técnicas produtivas, como o fordismo e o toyotismo.

Karnal (2007) define os anos 1920 como sendo da derrota da agenda progressista, seguida de crescimento econômico e retomada do conservadorismo na sociedade, política e cultura. Depois da recessão do pós-guerra, os americanos viveram uma fase de grande euforia econômica. No entanto, foi também uma era de contrastes, com acentuada desigualdade social, má-distribuição de renda e grande especulação financeira.

Essa década foi marcada especialmente pela explosão da sociedade de consumo. O progresso econômico imergiu a classe média em um estado de êxtase consumista. A propaganda estimulou a aquisição de novos bens e avanços tecnológicos em várias áreas garantiram a criação de novos produtos a preços acessíveis a esse extrato da população. Carros, geladeiras, luz elétrica, telefone, rádio, cinema, entre outros, eram produtos que antes eram consumidos apenas por uma parcela mais abastada da sociedade, mas agora estavam disponíveis para uma 
parte significativa dos norte-americanos. Consumir passou a ser sinônimo de status social e foi bastante incentivado no período (KARNAL, 2007).

Apesar dessa riqueza econômica, ainda existia uma distribuição de renda bastante desigual, com metade da população ainda vivendo no campo. Os produtos agrícolas, ao contrário dos industriais, não acompanharam o boom de crescimento e logo os excedentes de produção geraram uma forte queda de preços, consequentemente reduzindo também a renda dos pequenos proprietários (KARNAL, 2007).

\subsubsection{0: volta da hegemonia republicana}

A plataforma democrata de 1920 é bastante focada nos eventos do pós-guerra, em especial na Liga das Nações, cujo posicionamento é favorável, abordando aspectos positivos e essenciais da paz mundial moldada nesses princípios. Enaltece os princípios progressistas de justiça social, econômica e industrial, além da valorização da atuação do presidente Wilson na Conferência de Paz de Paris. Dessa forma, é um programa bastante voltado à política externa dos Estados Unidos.

No tocante econômico, ressaltam a importância da criação do Federal Reserve como fator inspirador de confiança para o crescimento norte-americano. A sua implantação, de acordo com os democratas, foi fundamental para a vitória na Grande Guerra. Ademais, suas autoridades não são partidárias, o que confere um tratamento das finanças imparcial e sem motivações adversas (DEMOCRATIC NATIONAL CONVENTION, 1920). Em relação a esse tópico, os democratas esclarecem:

Pela promulgação da Lei do Federal Reserve, o antigo sistema, que gerava pânicos,
foi substituído por um novo sistema, que assegura confiança. Foi um fator
indispensável para vencer a guerra, e hoje é a esperança e a inspiração dos negócios.
De fato, um perigo vital contra o qual o povo americano deve manter-se
constantemente vigilante, é o compromisso desse sistema aos inimigos partidários que
lutaram contra sua adoção e em vão tentaram reter nas mãos de banqueiros
especulativos o monopólio da moeda e dos créditos da nação. (DEMOCRATIC
NATIONAL CONVENTION, 1920, tradução elaborada pela autora)

A plataforma também é bastante crítica ao Partido Republicano em alguns aspectos, especialmente com a maioria republicana no Congresso nos últimos anos do mandato de Wilson. Condena os republicanos pela oposição acerca da revisão das leis tarifárias e de levar à arena partidária questões como o sistema bancário e monetário. Disserta também sobre o alto custo de vida que, de acordo com a visão democrata, apenas se resolve mediante o aumento da produção, e não à manutenção das altas tarifas protecionistas, conforme defendiam os 
republicanos. É necessária também a fiscalização às restrições comerciais e ao monopólio. O partido defende a criação da Comissão Federal do Comércio para assegurar a competitividade justa dos negócios. Ademais, deve haver supervisão dos mercados por parte do governo nacional, para melhor manutenção das ações interestatais. Por fim, o sistema orçamentário deve ser efetivo e funcionar de acordo com os princípios constitucionais (DEMOCRATIC NATIONAL CONVENTION, 1920).

A plataforma Republicana, segundo Bailey (1968), é demasiada ambígua. A desagregação do partido em 1912 e o constante risco de nova ruptura no pós-guerra, com partidários pró-Liga das Nações e contrários à Liga das Nações, trouxe a necessidade de tentar agradar ambos os lados, para que se consolidasse uma coesão partidária novamente. $\mathrm{O}$ candidato escolhido, Warren Harding, não apoiava a Liga, mas fora vago nessa questão durante a campanha.

O partido aponta a demanda por ajustes financeiros em tempos de paz, afirmando que o Partido Democrata ainda estava bastante engessado no contexto da guerra, com gastos extravagantes. Com isso, defende uma política de rigidez econômica e congratula a redução das estimativas de gastos auferida pelo Congresso republicano em quase 3 milhões de dólares. Ademais, os republicanos apontam a necessidade do estabelecimento de um Orçamento Executivo para regulação das finanças nacionais (REPUBLICAN NATIONAL CONVENTION, 1920).

Sobre a questão fiscal, os republicanos admitem que é necessária uma revisão tarifária, porém, classificam como precipitada a atitude da administração democrata em diminuir as tarifas básicas. Tal medida acarretou em redução da receita, gerando um grande endividamento que será herdado pelo próximo presidente. Criticam a também a posição financeira durante a guerra que, segundo o Partido Republicano, foi sustentada com inflação, empréstimos e títulos a taxas artificiais. Essas críticas foram rebatidas pelo Partido Democrata, que ressaltou que todo cidadão tem o direito e a legitimidade de financiar a guerra. A plataforma aponta, contudo, consequências no pós-guerra para essas políticas, que restringem o crédito para indústrias. Adicionalmente, afirma que o sistema do Federal Reserve deve se abster de intervenções partidárias e deve ser independente tanto da política quanto dos combinados empresariais (REPUBLICAN NATIONAL CONVENTION, 1920).

Em relação ao alto custo de vida, os republicanos possuem um posicionamento semelhante ao Partido Democrata no tocante a ter como causa a produção industrial reduzida. Quando se diminui a oferta agregada, a tendência é o aumento de preços para se alcançar o equilíbrio com a demanda agregada, que se encontra alargada. Apontam também os fatores 
tributários e o aumento da margem de lucros como motivos para esse crescimento, além da grande expansão monetária e de crédito (REPUBLICAN NATIONAL CONVENTION, 1920).

Por fim, na questão dos monopólios e conglomerados comerciais, o Partido Republicano apoia a legislação federal vigente, mas desde que assegure os 'negócios americanos' (REPUBLICAN NATIONAL CONVENTION, 1920). Nesse sentido, afirma que a Comissão Federal de Comércio, no governo democrata, não foi eficiente em cumprir sua finalidade. A plataforma se posiciona claramente na defesa da liberdade dos negócios e afirma que "não deve haver nenhuma perseguição de negócio honesto" (REPUBLICAN NATIONAL CONVENTION, 1920, tradução elaborada pela autora).

O resultado das eleições de 1920, de acordo com Bailey (1968), não foi surpreendente, pois configura-se como uma continuidade da predominância republicana que estava em vigência desde as eleições de 1860 . Dessa forma, os dois mandatos de Wilson teriam sido uma 'pausa' circunstancial a essa primazia, assim como foram os de Cleveland, intercalados, nos períodos de 1885 a 1889 e 1893 e 1897 . No caso de Wilson, tanto em 1912 quanto em 1916, a margem de votos nos resultados foi muito pequena, com vitórias apertadas. Com o Partido Republicano novamente unificado, a volta ao poder era inevitável. Tanto o mapa quanto a tabela que se seguem demonstram a vitória com ampla margem no colégio eleitoral:

Imagem 7 - Resultado das eleições de 1920

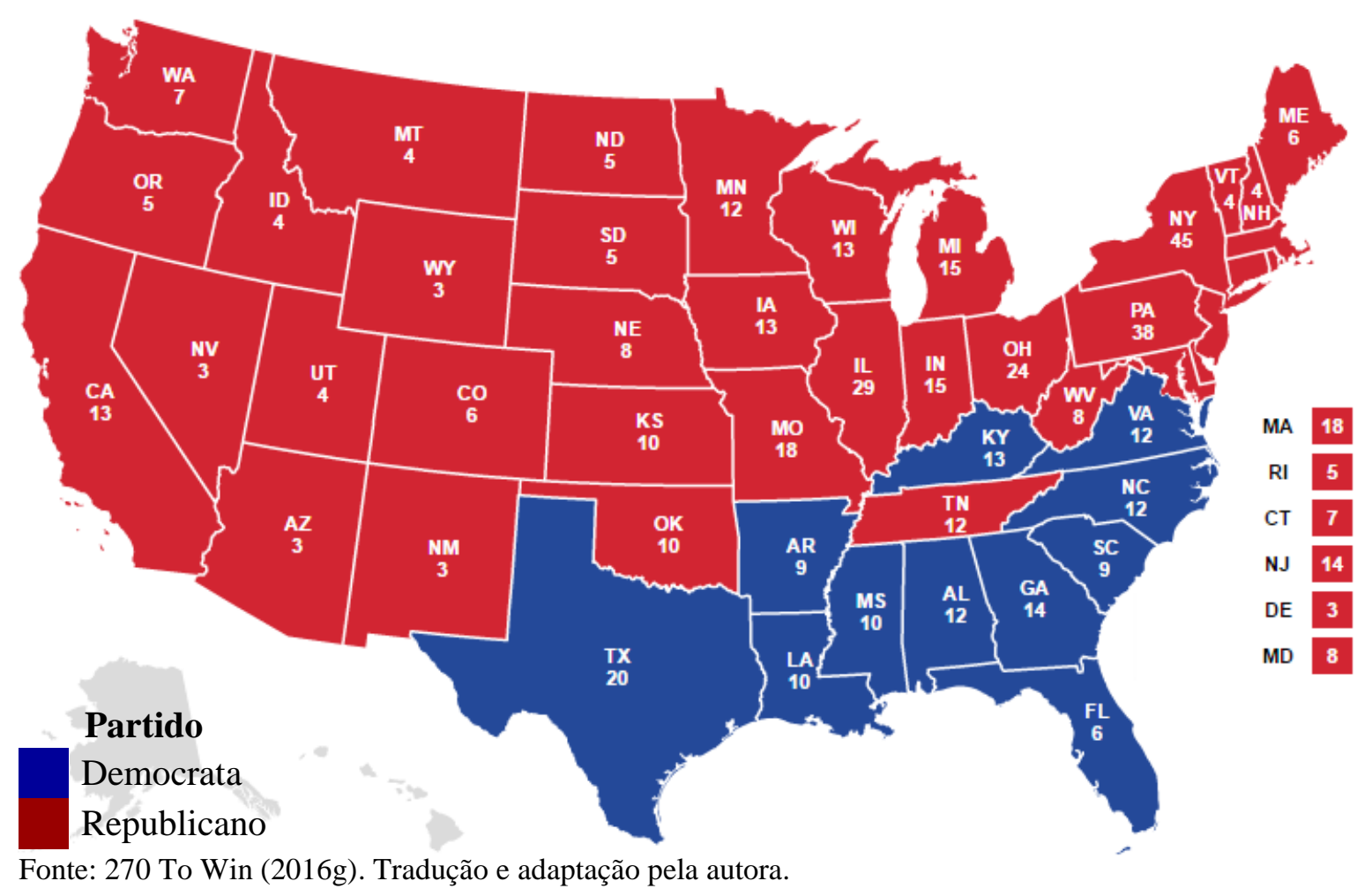


Tabela 7 - Resultado das eleições de 1920

\begin{tabular}{|c|c|c|c|c|c|c|}
\hline Candidato & Vice & $\begin{array}{l}\text { Partido } \\
\text { Político }\end{array}$ & \multicolumn{2}{|c|}{ Votos populares } & \multicolumn{2}{|c|}{$\begin{array}{c}\text { Votos } \\
\text { eleitorais }\end{array}$} \\
\hline $\begin{array}{l}\text { Warren } \\
\text { Harding }\end{array}$ & $\begin{array}{l}\text { Calvin } \\
\text { Coolidge }\end{array}$ & Republicano & 16.151 .916 & $60,3 \%$ & 404 & $76,1 \%$ \\
\hline James Cox & $\begin{array}{c}\text { Franklin } \\
\text { Roosevelt }\end{array}$ & Democrata & 9.134 .074 & $34,1 \%$ & 127 & $23,9 \%$ \\
\hline \multicolumn{3}{|c|}{ Total } & 26.768 .457 & $100 \%$ & 531 & $100 \%$ \\
\hline
\end{tabular}

Fonte: The American Presidency Project (2016h). Tradução e adaptação pela autora.

A vitória republicana nessas eleições inaugura uma nova era da política norte-americana (SHANNON, 1965) que perduraria por quase toda a década de 1920. A euforia e o progresso econômico foram características dessa década e o Partido Republicano se tornou central nessa propaganda. Contudo, o mandato de Harding foi bastante problemático, principalmente no tocante à corrupção. Chester (1977) concorda e afirma que o republicano pode ter sido considerado um dos piores presidentes, comparado a Ulysses Grant. Antes de muitos escândalos serem expostos, Harding faleceu, em agosto de 1923. Calvin Coolidge assumiu e concorreu à reeleição em 1924.

\subsubsection{4: "Keep cool with Coolidge"}

Na Convenção Republicana de 1924, Coolidge concorreu à nomeação presidencial com Robert La Follette e Hiram Johnson, tendo vencido com 1.065 votos (CHESTER, 1977). A plataforma do partido é bastante acusativa à administração anterior democrata, apontando as situações de desemprego e estagnação comercial e industrial presentes em 1921 (REPUBLICAN NATIONAL CONVENTION, 1924).

Ressaltam, então, que a administração de Harding, com a retomada da hegemonia republicana, foi essencial para reativar a indústria e o comércio, além de possibilitar a segurança dos créditos públicos e privados. O governo também efetuou uma política de rigidez na economia, reduzindo gastos e diminuindo impostos (REPUBLICAN NATIONAL CONVENTION, 1924).

Sobre o sistema de tributação, a plataforma é enfática demandando uma reforma eficiente: 
Somos a favor da criação, por legislação adequada, de uma comissão federal nãopartidária para fazer um estudo abrangente e um relatório sobre o sistema fiscal dos estados e governo federal, com vista a uma reforma inteligente dos nossos sistemas de tributação a uma base mais equitativa e uma ajuste adequado dos assuntos de tributação entre os governos nacionais e estaduais com justiça para o contribuinte e em conformidade com os princípios econômicos sólidos. (REPUBLICAN NATIONAL CONVENTION, 1924, tradução elaborada pela autora)

O documento retorna também à questão das tarifas protecionistas, afirmando que são de suma necessidade para uma efetiva proteção à competitividade das indústrias nacionais e enfatizando que esta deve se configurar como política nacional. A aplicação das leis tarifárias contribui, segundo os republicanos, para a estabilidade dos negócios. Ademais, defendem a necessidade de se efetuar melhorias no sistema ferroviário, meta que se mostra compatível com os ajustes econômicos do país (REPUBLICAN NATIONAL CONVENTION, 1924).

Por fim, abordam questões trabalhistas, afirmando apoiar melhorias, como a redução da jornada para oito horas diárias, referências à emenda do presidente Coolidge acerca do trabalho infantil, além de enfatizar a importância da educação vocacional. Ademais, dissertam sobre relações de trabalho e opinião pública:

A negociação coletiva, a mediação voluntária e arbitragem são os passos mais
importantes na manutenção de relações de trabalho pacíficas. Nós não acreditamos
em ação obrigatória em nenhum momento. A opinião pública deve ser o árbitro final
em qualquer crise que afeta tão vitalmente bem-estar público, como a suspensão do
transporte. Portanto, os interesses do público requerem a manutenção de um tribunal
imparcial que pode em qualquer emergência fazer uma investigação do fato e publicar
suas conclusões. Este é aceito como base do julgamento popular. (REPUBLICAN
NATIONAL CONVENTION, 1924, tradução elaborada pela autora).

A plataforma do Partido Democrata se inicia também acusatória, assim como a do Partido Republicano. Após homenagem à memória do presidente Wilson (a republicana igualmente começa com referências a Harding, que havia falecido no ano anterior), faz referências à ideia de que a agremiação no poder entendia que privilégios especiais são essenciais à prosperidade nacional. Os democratas defendem que os direitos devem ser iguais a todos, sem leis discriminatórias e injustas. Fazem, então, comparações entre os oito anos da administração de Wilson e o último mandato republicano, falando sobre conquistas democratas que ocasionaram em um período de 'progresso social e material'. Denunciam, ademais, a corrupção do governo vigente (DEMOCRATIC NATIONAL CONVENTION, 1924).

A plataforma republicana não aborda o assunto dos monopólios. A defesa das tarifas protecionistas pelos republicanos é feita sem menções ao problema dos conglomerados. Os democratas, no entanto, denunciam a Lei Tarifária Fordney-McCumber e demais leis tarifárias republicanas conduzindo o assunto a esse eixo: 
Denunciamos as leis tarifárias republicanas que foram escritas, em grande parte, em ajuda aos monopólios e, assim, evitando que trocas razoáveis de commodities que poderiam permitir aos países estrangeiros comprarem nossos produtos agrícolas e manufaturados excedentes, resultando em lucro para os trabalhadores e produtores da América. (DEMOCRATIC NATIONAL CONVENTION, 1924, tradução elaborada pela autora)

Os democratas ainda destacam:

A Comissão de Comércio Federal submeteu à administração republicana numerosos
relatórios mostrando a existência de monopólios e combinações de restrição de
comércio, e recomendou processos contra esses violadores da lei. Os poucos
processos que resultaram dessa abundante evidência fornecida por esta agência criada
pelo Partido Democrata, enquanto provando a indiferença da administração às
violações da lei por trustes e monopólios e sua simpatia por eles, mesmo assim
demonstram o valor da Comissão de Comércio Federal. Nós declaramos que um
monopólio privado é indefensável e intolerável, e prometemos que o Partido
Democrata irá aplicar rigorosamente as leis existentes contra monopólios e
combinações ilegais, e promulgar futuras medidas adicionais que possam ser
necessárias. (DEMOCRATIC NATIONAL CONVENTION, 1924, tradução
elaborada pela autora)

O ponto econômico central de embate entre os partidos Republicano e Democrata é, novamente, a questão do protecionismo. Os republicanos continuam a defender a importância da proteção das indústrias nacionais, enquanto que os democratas adotam uma visão mais liberal, de que uma maior liberdade no mercado internacional seria mais benéfica tanto às indústrias quanto à agricultura dos Estados Unidos.

O comércio internacional, conforme defendido na plataforma democrata, é essencial ao desenvolvimento de vantagens recíprocas nos países (DEMOCRATIC NATIONAL CONVENTION, 1924). É o princípio econômico das vantagens comparativas, em que os países se especializam nos produtos que possuem menor custo e maior eficiência de fabricação, sendo o comércio essencial para ampliar a efetividade de todas os produtores.

Ademais, o Partido Democrata é também acusatório na questão agrícola, afirmando que o governo republicano, em sua política isolacionista, não permitiu o retorno dos países europeus à normalidade da balança comercial, gerando prejuízos aos agricultores norte-americanos. A tarifa protecionista também privou esses trabalhadores do campo de adquirir manufaturados a preços mais competitivos, forçando-os a comprarem a preços elevados das indústrias domésticas. Assim, a renda desse segmento diminuiu ainda mais, adicionando-se à deficiência do mercado de exportações A visão do Partido Democrata para resolver esses problemas é a geração de um comércio internacional cooperativo, reajustando tanto o mercado externo como o interno (DEMOCRATIC NATIONAL CONVENTION, 1924).

Os democratas também abordam a contração de crédito e moeda, resultante da política de rigidez econômica. Os empréstimos bancários foram reduzidos, o que gerou diversas 
falências industriais, assim como agravou a situação dos trabalhadores do campo. Para o partido, deveria haver uma melhor administração do sistema de reservas federal, gerando estabilidade financeira e monetária (DEMOCRATIC NATIONAL CONVENTION, 1924).

Robert La Follette perdeu as primárias do Partido Republicano e então, para concorrer à presidência, fundou o Partido Progressista. Em 1912, conforme já abordado, La Follette, juntamente com Theodore Roosevelt, havia feito parte da constituição do partido com esse mesmo nome, porém, que teve seu fim em 1919. O líder refunda a agremiação e Chester (1977) descreve a sua plataforma como em parte populista e em parte progressista.

Os progressistas fazem uma denúncia ao controle do governo e da indústria por monopólios privados, afirmando que são nocivos à competitividade, obstruindo o funcionamento de empresas independentes. Também referenciam Jefferson e Lincoln na defesa da igualdade de oportunidades. A plataforma tece críticas a ambos os partidos hegemônicos na ineficiência em combater os grandes conglomerados (PROGRESSIVE NATIONAL CONVENTION, 1924).

É bem significativa a presença de demandas referentes ao direito dos agricultores. Os progressistas criticam a visão de que a prosperidade está restrita às grandes corporações, beneficiárias de políticas de crédito praticamente ilimitadas e tarifas altas. Os produtos agrícolas, por outro lado, permanecem deflacionados, reduzindo a renda do segmento e aumentando seus custos, com produtos industriais a preços elevados. É preciso reduzir as tarifas protecionistas e reconstruir o sistema de empréstimos a agricultores. Ademais, adentram na questão ferroviária, demandando a reforma dos preços e continuidade de investimentos. Por fim, são favoráveis à redução dos impostos federais sobre renda individual e à política de rigidez econômica do governo. De acordo com a plataforma, é necessária a recuperação da economia nacional, afetada com contratos fraudulentos do período da guerra e com a corrupção acentuada (PROGRESSIVE NATIONAL CONVENTION, 1924).

Coolidge, do Partido Republicano, conseguiu garantir a vitória com tranquilidade, conseguindo $71,9 \%$ dos votos eleitorais. Nas eleições populares, o Partido Democrata conseguiu apenas alguns estados do Sul, enquanto que os republicanos foram vitoriosos em quase todos do Norte e Oeste. La Follette, progressista, angariou apenas o seu estado natal, Wisconsin, conseguindo 13 votos no colégio eleitoral. Dessa forma, a primazia republicana continuava e os resultados podem ser observados no mapa e na tabela a seguir: 
Imagem 8 - Resultado das eleições de 1924

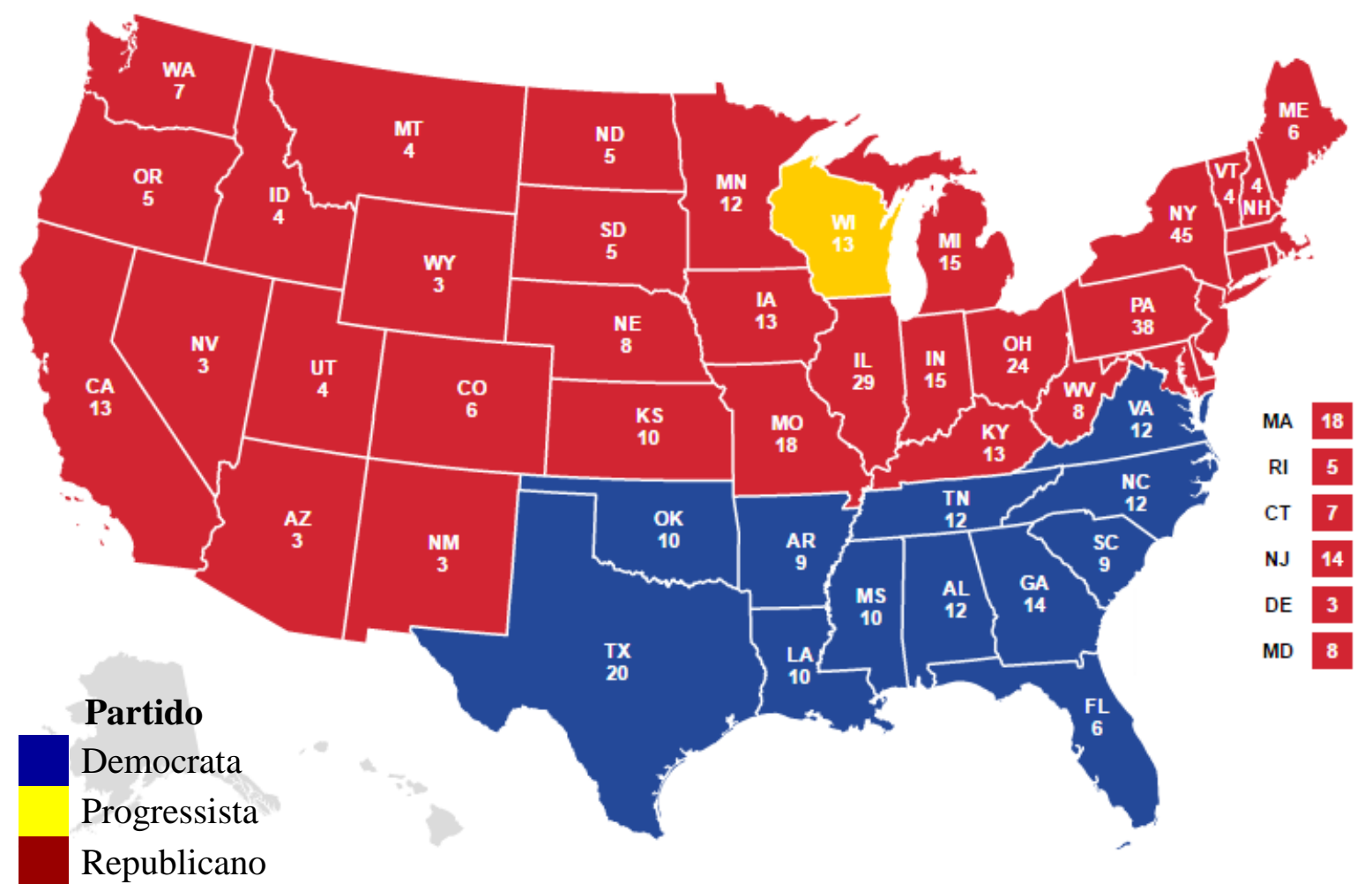

Fonte: 270 To Win (2016h). Tradução e adaptação pela autora.

Tabela 8 - Resultado das eleições de 1924

\begin{tabular}{|c|c|c|c|c|c|c|}
\hline \multirow{2}{*}{$\begin{array}{c}\text { Candidato } \\
\text { Calvin } \\
\text { Coolidge }\end{array}$} & \multirow{2}{*}{$\begin{array}{c}\text { Vice } \\
\text { Charles } \\
\text { Dawes }\end{array}$} & \multirow{2}{*}{$\begin{array}{c}\begin{array}{c}\text { Partido } \\
\text { Político }\end{array} \\
\text { Republicano }\end{array}$} & \multicolumn{2}{|c|}{ Votos populares } & \multicolumn{2}{|c|}{$\begin{array}{c}\text { Votos } \\
\text { eleitorais }\end{array}$} \\
\hline & & & 15.724 .310 & $54,0 \%$ & 382 & $71,9 \%$ \\
\hline John Davis & $\begin{array}{c}\text { Charles } \\
\text { Bryan }\end{array}$ & Democrata & 8.386 .532 & $28,8 \%$ & 136 & $25,6 \%$ \\
\hline $\begin{array}{l}\text { Robert La } \\
\text { Follette }\end{array}$ & $\begin{array}{c}\text { Burton } \\
\text { Wheeler }\end{array}$ & Progressista & 4.827 .184 & $16,6 \%$ & 13 & $2,4 \%$ \\
\hline \multicolumn{3}{|c|}{ Total } & 29.099 .380 & $100 \%$ & 531 & $100 \%$ \\
\hline
\end{tabular}

Fonte: The American Presidency Project (2016i). Tradução e adaptação pela autora.

\subsubsection{Perspectivas da década de 1920}

Durante toda a década de 1920, os Estados Unidos estiveram sob administração do Partido Republicano. Nesse período, conforme considerado por Shannon (1965), os republicanos retornaram a um paradigma partidário que existia anteriormente a Theodore Roosevelt, como uma volta às tradições que permearam os governos do pós-guerra civil, especialmente da década de 1890. As políticas se configuraram de forma mais conservadora, retornou-se os altos índices tarifários e houve pouco esforço para se evitar privilégios econômicos, tais como monopólios (SHANNON, 1965). 
Percebe-se, então, com as administrações de Harding, Coolidge e Hoover (que será abordada no próximo capítulo), o fim do movimento progressista, que havia sido proclamado no início do século XX com Theodore Roosevelt e depois com Woodrow Wilson. O principal ponto de divergência entre os republicanos e democratas era a questão das tarifas protecionistas, conforme já atestado nas plataformas partidárias abordadas. Na administração democrata de Wilson, houve revisão tarifária, mas a expectativa era de retorno às altas taxas na década de 1920. Sobre esse aspecto, Shannon (1965, p.36, tradução elaborada pela autora) afirma:

Todo mundo esperava um aumento nas alíquotas tarifárias com o retorno do Partido
Republicano ao poder. Historicamente, os Republicanos têm sido protecionistas. Os
Democratas, apesar de não totalmente favoráveis ao livre mercado, foram bem mais
favoráveis a modestas tarifas protecionistas. Em 1913, a administração de Wilson
passou ao Congresso a primeira revisão tarifária decrescente desde a década de 1890
e a primeira importante desde a Guerra Civil, mas essa tarifa Democrata tinha operado
apenas brevemente em circunstâncias normais. A eclosão da guerra na Europa, no ano
seguinte de sua aprovação, impediu fortemente as manufaturas europeias de serem
exportadas para os Estados Unidos e a Europa era a principal fonte de manufaturados
importados. Com o fim da guerra e a retomada da produção normal no Velho Mundo,
os fabricantes americanos temiam a concorrência estrangeira.

Bailey (1968) reitera a associação entre a volta dos republicanos ao poder e a vigorosa prosperidade econômica. Segundo o autor, "a velha guarda estava de volta" (BAILEY, 1968, p.103, tradução elaborada pela autora) e, com isso, se perceberia uma aceleração dos negócios com a ressalva de afastamento da participação direta do Estado na economia. Em suas palavras: “mais negócio no governo e menos governo no negócio" (BAILEY, 1968, p.103, tradução elaborada pela autora). É sinalizada uma ruptura com o modo de operação da administração anterior, Wilson havia se mostrado um chefe de executivo forte e presente, assim como Theodore Roosevelt havia sido. A fase do Partido Republicano que permeou a década de 1920 era considerada como 'tradicional', buscando suas raízes no século XIX, por isso a escolha de palavras de retorno da 'velha guarda'.

O período de expansão econômica era visível, apesar de alguns momentos de recessão. Em 1921, houve uma crise, com elevação do desemprego, queda da renda nacional e especial declínio dos produtos agrícolas. Contudo, já em 1922, a força da economia já estava de volta. Perceberam-se pequenas flutuações em 1924 e 1927, mas cíclicas e passageiras (SHANNON, 1965). Todavia, apesar dessas oscilações em alguns segmentos, a economia estava fluindo de maneira extremamente positiva, com significativo aumento da renda per capita real.

Algumas atividades, no entanto, não obtiveram o mesmo sucesso, sendo a agropecuária o setor que mais se destaca no mesmo sentido. Shannon (1965) afirma que os seus preços não se recuperaram completamente desde a guerra, sendo depois um dos segmentos que mais sofreu 
com a depressão. A produção havia crescido bastante desde o fim do século XIX devido a inovações tecnológicas e incorporações de fertilizantes; esse aumento de oferta gerou excessos que deflacionaram os preços, afetando também os salários dos trabalhadores rurais. Com a Grande Guerra, a situação se agravou, uma vez que a demanda europeia por produtos agrícolas norte-americanos praticamente deixou de existir (LIMONCIC; MARTINHO, 2009).

John Kenneth Galbraith cita declaração do presidente Calvin Coolidge (em dezembro de 1928) sobre a prosperidade da economia americana: "A principal fonte desta bemaventurança sem precedentes repousa na natureza e na integridade do povo norte-americano" (GALBRAITH, 1988, p.3). Nesta declaração, o então presidente manifestava satisfação quanto ao presente e otimismo quanto ao futuro. A confiança governamental no período refletia a euforia em toda a sociedade norte-americana. 


\section{CAPÍTULO 3}

\subsection{O melhor momento do capitalismo norte-americano}

Galbraith (1988) caracteriza a chegada ao final da década de 1920 como a fase de mais acentuada prosperidade do capitalismo norte-americano. O nível de produção industrial estava alto, assim como os níveis de emprego. Um dos pontos levantados por Galbraith para explicar a prosperidade da década de 1920 e posteriormente a quebra da bolsa era a característica da população dos Estados Unidos de possuir como característica um "desejo desordenado de enriquecer rapidamente e com o menor esforço possível” (GALBRAITH, 1988, p.5).

No começo da década de 1920, começou um movimento expansionista no mercado de ações. Os preços estavam baixos no pós-guerra e favoráveis a rendimentos. A possibilidade de fácil enriquecimento surgiu nesses mercados, em que ações eram compradas a pequenos preços e grande expectativa de lucros, se popularizando esse tipo de atividade. A demanda por essas ações aumentou vertiginosamente e, com isso, seguindo os princípios de oferta e demanda, os preços subiram, gerando uma supervalorização acionária. O número de ações negociadas aumentava a cada mês; em novembro de 1928, o volume de 6.641 .250 de ações foi negociado. A especulação estava se tornando cada vez mais recorrente, e o preço das ações subia continuamente, em um boom financeiro (GALBRAITH, 1988).

O movimento da bolsa de valores gerou uma ampla especulação que, segundo Sabadini (2013) configura-se como um instrumento de capital fictício. A sua remuneração advém de um lado "do pagamento dos juros; por outro, vem das oscilações especulativas dos preços dos ativos, que chamamos de lucros fictícios" (SABADINI, 2013, p.603). A primeira explosão especulativa aconteceu no mercado imobiliário da Flórida, baseada na expectativa do aumento do fluxo de turistas no estado durante o verão. Terrenos com baixo valor se valorizaram e as condições de pagamento eram facilitadas (entrada de 10\%). A demanda foi aumentando e os lotes crescendo, cada vez mais distantes da praia. No entanto, começou-se a declinar o número de compradores a partir de 1926 e, com isso, os preços também caíram (GALBRAITH, 1988).

A partir do início de 1928, Galbraith (1988) afirma que houve alteração no movimento especulativo. Segundo o autor, percebeu-se uma "fuga em massa da realidade para a fantasia" (GALBRAITH, 1988, p.12). Houve uma desaceleração em 1926, devido ao fim do boom da Flórida, mas em 1927 o crescimento retorna e toma proporções inimagináveis.

No entanto, Kindleberger (1986) afirma que o crescimento econômico não foi generalizado em toda a década de 1920 e também não alcançou todas as atividades (conforme 
já ressaltado). Sinais de tensão apareceram durante todo o período, ganhando destaque a recessão de 1927, em que o índice industrial (definido a partir da comparação com os anos de 1923 a 1925) caíram de 111 em maio para 99 em novembro. Segundo o autor, tal queda influenciou a decisão de redução da taxa de juros básica nos Estados Unidos, também com a finalidade de ajuda financeira à Europa. $\mathrm{O}$ acúmulo de estoques no setor primário também permeou praticamente durante todos esses anos, gerando queda de preços e incapacidade de pagar empréstimos contraídos.

O principal boom em território americano se concentrou no setor automobilístico, tanto na produção de veículos quanto nos setores auxiliares, como peças, refinarias de petróleo e ampliação de estações de gasolina (KINDLEBERGER, 1986). Gazier (2009, p.35) apresenta os seguintes números acerca do crescimento anual de automóveis fabricados: 1,9 milhões em 1919 comparados a 5,6 milhões em 1929.

\subsection{Plataformas partidárias de 1928}

O início da plataforma do Partido Republicano de 1928 sinaliza amplamente o otimismo com a prosperidade do país. São enaltecidas as conquistas sob a administração do partido conforme atesta-se a seguir:

Sob inspiração Republicana e largamente sob direção executiva Republicana o
continente foi ligado por trilhos de aço, os oceanos e grandes rios foram unidos por
canais, hidrovias têm sido aprofundadas e alargadas para o comércio oceânico, e com
tudo isso um alto padrão americano de salário e de vida foi estabelecida.
(REPUBLICAN NATIONAL CONVENTION, 1928, tradução elaborada pela autora)

O sentimento de euforia é evidente no documento, sendo proclamadas a obtenção, nos governos republicanos, de estabilidade e confiança no comércio. No tocante às políticas econômicas, são abordadas na plataforma os eixos do orçamento público, da tarifa protecionista e das ferrovias. Ademais, também é relevante versar sobre a questão do trabalho e como ela é tratada pelo partido.

Com relação à economia pública, os republicanos apontam reajustes orçamentários feitos no governo de Coolidge, com políticas que geraram evidentes resultados desde o início da década, com redução do déficit fiscal. São feitas denúncias ao comportamento desorganizado da administração de Wilson, sob tutela democrata, que consistia em escassez de crédito, dívida pública significante e impostos com finalidades militares. Segundo os republicanos, todos esses problemas supracitados foram solucionados durante os mandatos deste partido (REPUBLICAN NATIONAL CONVENTION, 1928). 
De maneira pormenorizada são feitas as considerações acerca das tarifas protecionistas. Em conformidade com plataformas anteriores, os republicanos são extremamente enfáticos em sua defesa, inserida pelo partido como princípio indispensável e elementar da economia do país. Com a revisão tarifária colocada em prática no primeiro mandato da década de 1920, percebeuse elevação da atividade industrial, culminando assim na redução do desemprego (REPUBLICAN NATIONAL CONVENTION, 1928). Essa questão da legislação protecionista é uma das principais em todas as outras plataformas analisadas, no entanto, a de 1928 tem uma particularidade: é enfatizado o alcance dos seus benefícios para todas as classes, particularizando-se na situação dos agricultores, alvo de críticas por parte dos democratas.

O Partido Republicano acredita que o mercado doméstico, construído no âmbito da política protecionista, pertence ao agricultor americano, e reitera o seu apoio à legislação que dará a ele este mercado em toda a extensão da sua capacidade de fornecê-lo. São derivados à agricultura grandes benefícios não só diretamente da proteção incidente sobre produtos agrícolas competitivos de origem estrangeira, mas também, indiretamente, a partir do aumento do poder de compra dos trabalhadores americanos empregados nas indústrias igualmente protegidas. Esses benefícios se estendem também às pessoas envolvidas no comércio, transporte e outras atividades. (REPUBLICAN NATIONAL CONVENTION, 1928, tradução elaborada pela autora)

No que se refere a questões de trabalho, o Partido Republicano afirma que os americanos são os trabalhadores com mais altos salários e padrões de vida verificados em todos os países. Novamente, é colocado o protecionismo em foco, apontado como uma das principais razões para essa conquista. Ressaltam também a defesa da liberdade de contratos salariais, como forma de ampliar a competitividade. (REPUBLICAN NATIONAL CONVENTION, 1928). Esse é um princípio claramente liberal, uma vez que considera a autorregulação do mercado, em que a oferta e a demanda de mão-de-obra se encontram em um ponto de equilíbrio. Assim como outros preceitos do liberalismo, este será colocado em reavaliação após a quebra da bolsa em 1929. Além disso, os republicanos afirmam que disputas trabalhistas em alguns casos têm sido abusivas, gerando problemas ao sistema.

Por fim, sobre as ferrovias, a plataforma faz elogios ao trabalho dos governos republicanos, colocando esse meio de transporte com serviço de qualidade a preços reduzidos.

O Partido Republicano iniciou e colocou em operação a Comissão Interestatal de Comércio. Este órgão tem desenvolvido um sistema de controle e regulamentação das estradas de ferro que tem dado ao público em transporte não apenas uma oportunidade de fazer sugestões para a melhoria do serviço ferroviário, mas para protestar contra taxas ou horários discriminatórios. Nós elogiamos o trabalho que este órgão está realizando sob mandato da lei em considerar essas questões e buscar distribuir equitativamente a carga de transporte entre commodities baseada em sua capacidade de suportá-la. (REPUBLICAN NATIONAL CONVENTION, 1928, tradução elaborada pela autora) 
Os democratas não diferem tanto dos republicanos em alguns conteúdos relevantes. Possuem um pensamento semelhante no tocante às relações trabalhistas, sendo favoráveis também à negociação coletiva e condenando abusos apontados em certas disputas. Nesse último caso, são mais detalhistas do que o primeiro partido citado:

Reconhecemos que as investigações legislativas e outras têm demonstrado a existência de abusos graves na emissão de liminares em disputas trabalhistas. Nenhuma injunção deve ser concedida em conflitos laborais, salvo mediante prova de danos irreparáveis e após aviso prévio e audição e a liminar deve limitar-se aos atos que ameaçam diretamente tais danos irreparáveis. (DEMOCRATIC NATIONAL CONVENTION, 1928, tradução elaborada pela autora)

O Partido Democrata reitera seu compromisso em acabar com monopólios, para salvaguardar tanto os grandes quanto os pequenos negócios. Acusa, assim, as administrações republicanas de negligência no cumprimento das leis antitruste. Se faz necessária, para resolver a questão, a aplicação rigorosa de tal legislação, além da construção de novos mecanismos que porventura se mostrem necessários. Os democratas também defendem a reorganização das finanças governamentais, com reestruturação do corpo burocrático. Afirmam que os governos republicanos não conquistaram a redução dos gastos, que teriam ocorrido devido ao fim das despesas geradas na guerra (DEMOCRATIC NATIONAL CONVENTION, 1928).

Na plataforma, também é ressaltada a importância e o valor do Federal Reserve, enfatizando o fato de ter sido uma contribuição democrata. Acusam, no entanto, o uso exacerbado do sistema objetivando vantagens aos especuladores do mercado de ações. Em relação à legislação tarifária, os democratas são bastante incisivos no combate aos monopólios e na garantia de uma tarifa benéfica a todos os segmentos. No final deste plank, afirmam: "assalariado, fazendeiro, pecuarista, produtor e negócios legítimos em geral, têm tudo a ganhar com uma tarifa Democrática baseada na justiça para todos” (DEMOCRATIC NATIONAL CONVENTION, 1928, tradução elaborada pela autora). Todavia, não pormenorizam as políticas que deverão ser adotadas, apenas afirmam que deve ser salvaguardado o negócio e o trabalhador norte-americanos. Ademais, percebe-se que não são específicos sobre reduzir ou não a tarifa protecionista, como havia sido nas plataformas anteriores, em que era bem marcante a defesa da diminuição. Declaram, no entanto, que a legislação tarifária favorece amplamente o setor industrial, em detrimento da agropecuária (DEMOCRATIC NATIONAL CONVENTION, 1928).

A era da prosperidade, que permeou toda a década de 1920, chegou a seu ápice nessas eleições. O cenário era amplamente favorável ao Partido Republicano, que havia conduzido o país durante esses anos. Herbert Hoover era o candidato ideal; na 'era da tecnologia', nada 
melhor do que um engenheiro à frente da Casa Branca (SHANNON, 1965). Havia sido Secretário do Comércio durante as administrações de Harding e Coolidge e desde então defendia o 'negócio americano'. Shannon (1965) discorre sobre a visão de Hoover sobre o assunto, afirmando que o governo deveria auxiliar o negócio, mas sem administrá-lo diretamente.

Hoover foi então eleito nesse contexto de expansão econômica com bastante folga no colégio eleitoral. No mapa e na tabela abaixo, os números podem ser atestados:

Imagem 9 - Resultado das eleições de 1928

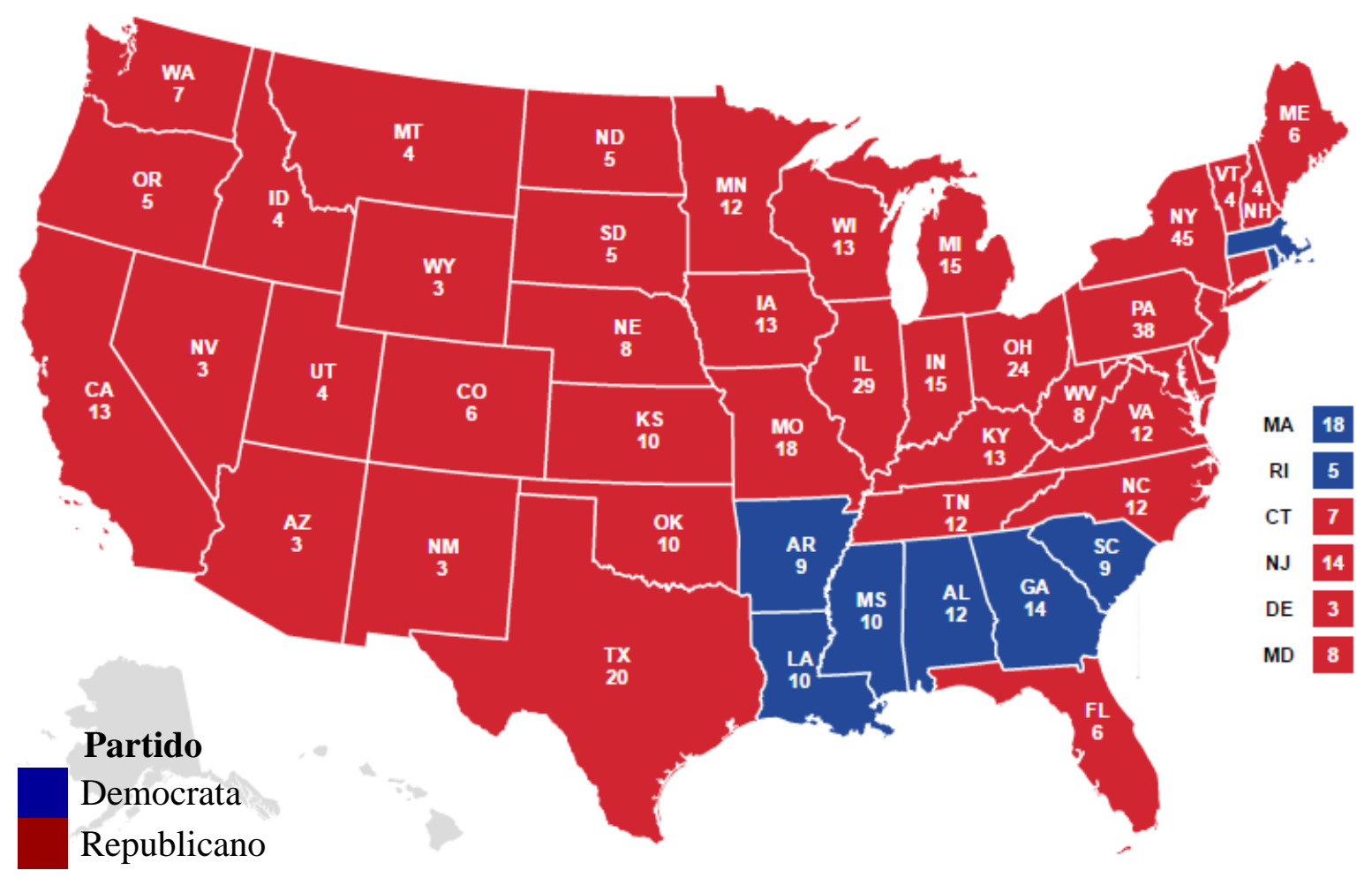

Fonte: 270 To Win (2016i). Tradução e adaptação pela autora.

Tabela 9 - Resultado das eleições de 1928

\begin{tabular}{|c|c|c|c|c|c|c|}
\hline Candidato & Vice & $\begin{array}{l}\text { Partido } \\
\text { Político }\end{array}$ & \multicolumn{2}{|c|}{ Votos populares } & \multicolumn{2}{|c|}{$\begin{array}{c}\text { Votos } \\
\text { eleitorais }\end{array}$} \\
\hline Herbert Hoover & $\begin{array}{l}\text { Charles } \\
\text { Curtis }\end{array}$ & Republicano & 21.432 .823 & $58,2 \%$ & 444 & $83,6 \%$ \\
\hline Alfred Smith & $\begin{array}{c}\text { Joseph } \\
\text { Robinson }\end{array}$ & Democrata & 15.004 .336 & $40,8 \%$ & 87 & $16,4 \%$ \\
\hline \multicolumn{3}{|c|}{ Total } & 36.801 .510 & $100 \%$ & 531 & $100 \%$ \\
\hline
\end{tabular}

Fonte: The American Presidency Project (2016j). Tradução e adaptação pela autora. 
Galbraith (1988) afirma que Hoover manifestou preocupações acerca da especulação exacerbada e os níveis que estava atingindo em 1925. Contudo, esses receios não foram disponibilizados ao público, mantendo-se na campanha o grande otimismo. Com sua vitória nas eleições, houve um grande boom na venda de títulos. "Longe de gerar pânico, a notícia de sua eleição provocou a maior elevação até hoje ocorrida na compra de títulos. A 7 de novembro, dia seguinte ao da eleição, houve o 'boom da vitória', quando os papéis mais importantes do mercado subiram de 5 a 15 pontos" (GALBRAITH, 1988, p.16).

\subsection{Colapso econômico}

A bolha especulativa estava atingindo níveis sem precedentes no final de 1928. Sobre as características dessa dimensão, Galbraith (1988, p.17) elucida:

\footnotetext{
Como se sabe, em certo ponto do crescimento de um boom, todos os aspectos da posse legal de um bem tornam-se irrelevantes, exceto a perspectiva de elevação imediata no preço. A renda proporcionada pelos bens ou a fruição de seu uso, ou mesmo seu valor a longo prazo, tudo passa a ser teórico.
}

Ou seja, o valor real das ações, das empresas em si, não importava mais, apenas a expectativa de aumento de preços e do lucro esperado. Ademais, não era necessário ter a posse real da empresa, imóvel ou outros bens. No caso do movimento imobiliário da Flórida, conforme exemplifica o autor, eram transacionadas "promessas de venda" (GALBRAITH, 1988, p.18):

\footnotetext{
Não se comprava a própria terra, mas sim o direito de adquiri-la por determinado preço. Esse direito de compra - que se adquiria com uma entrada de $10 \%$ do valor estipulado para o lote - podia ser vendido. Ele conferia, assim, aos especuladores, o pleno benefício da elevação do valor. Depois que o valor do lote tivesse subido, o adquirente podia revender a "promessa de venda" pela que havia pago e mais a quantia equivalente ao aumento ocorrido no preço. (GALBRAITH, 1988, p.18)
}

Como é um mercado movido a partir de expectativas, a partir do momento em que as pessoas passam a esperar que os preços vão cair, começam a vender ações e, à medida que mais ações são vendidas, mais os preços gerais declinam. O rompimento da bolha financeira ocorreu em outubro de 1929, com a "queda repentina das cotações da Bolsa de Nova York" (GAZIER, 2010, p.9) e promoveu uma crise generalizada. Ademais, também foi bastante pertinente para a depressão a grande superprodução de mercadorias. Com a economia em alta, as empresas tinham bastante expectativa de elevada demanda, então a oferta de produtos cresceu vertiginosamente. No entanto, com a crise, se multiplicaram o volume dos estoques não consumidos, gerando prejuízos e, com isso, demissões e falências. 
A depressão nos Estados Unidos está relacionada primordialmente a quatro aspectos: declínio da atividade industrial, dificuldades agrícolas, saturação do setor imobiliário e desorganização bancária (GAZIER, 2010).

É preciso enfatizar a especificidade dos problemas americanos - a facilidade com que era possível criar um banco, mesmo minúsculo, levara a uma grande indisciplina na área. A depressão americana consistiu, acima de tudo, num estrangulamento do crédito (credit crunch) e da confiança. (GAZIER, 2010, p.42)

Não havia um sistema bancário unificado, os bancos estavam submetidos a legislações locais. Ademais, a maior parte dos bancos criados se encontrava em cidades pequenas, onde a redução dos depósitos é mais acentuada, devido ao declínio das atividades e aumento do desemprego, especialmente em áreas camponesas (GAZIER, 2010).

Karnal (2007) aponta alguns efeitos da crise durante o mandato de Hoover, na primeira fase da depressão: diminuição abrupta do PIB e dos preços, queda da produção industrial, falência bancária (cerca de 5 mil bancos fecharam entre 1929 e 1932). O declínio de produção gera diminuição da renda das empresas, o que ocasiona em falências de diversas indústrias. Esse efeito acarreta em desemprego, que chegou à média de 20\% durante toda a década de 1930 (KARNAL, 2007). Essas pessoas desprovidas de renda consumiam menos, reduzindo a demanda agregada e, por conseguinte, levando à acumulação de estoques cada vez maiores nas indústrias. A perda de receitas suscitou mais falências e mais desemprego, levando a um ciclo vicioso de pânico.

Antes da quebra da bolsa, Hoover havia sancionado a Lei de Comercialização Agrícola, em que criou o Conselho Federal de Agricultura, que tinha como finalidade a manutenção dos preços de produtos agropecuários. Contudo, as suas políticas não foram eficientes e o órgão teve suas atividades encerradas em 1933 (CHESTER, 1977). Além dessa, as intervenções públicas tinham como principais eixos monetários a manipulação da taxa de redesconto e nas operações de open market ${ }^{17}$, mas que também não conseguiram resolver os problemas financeiros.

\subsection{Plataformas partidárias de 1932}

A plataforma do Partido Democrata de 1932 é demasiadamente curta, em comparação com documentos de anos anteriores. É bastante pragmática e tem dois objetivos: demonstrar a incapacidade administrativa do Partido Republicano em lidar com a crise e propor soluções

\footnotetext{
${ }^{17}$ Operações de open market se referem a compra e venda de títulos da dívida pública pelo governo como forma de controlar a oferta de moeda dentro da economia.
} 
(apesar de não detalhadas) para a situação alarmante que havia se formado. No início, é feita a declaração de as causas dominantes da depressão em curso consistiam nas ditas "políticas desastrosas" (DEMOCRATIC NATIONAL CONVENTION, 1932, tradução elaborada pela autora) aplicadas pelo governo desde a Guerra Mundial. São apontados como erros cruciais o isolacionismo econômico, que prejudicou o comércio exterior; a permanência de monopólios e o incentivo à manipulação do crédito com vista ao lucro. Deve haver, portanto, uma "drástica mudança nas políticas econômicas governamentais" (DEMOCRATIC NATIONAL CONVENTION, 1932, tradução elaborada pela autora).

Enquanto que a plataforma de 1928 havia sido bastante explicativa, esta é sucinta, abordando os tópicos de forma rápida e até, de certa forma, aparentemente apressada. Ao longo do tempo, a escrita desses documentos passou por aperfeiçoamentos e modificações, ficando mais complexos e longos, sendo divididos em planks, ou seja, temas de interesse do programa. A plataforma de 1932 não é dividida em pontos específicos, sendo praticamente um texto corrido, com cada questão discutida de forma breve.

Percebe-se que a maior parte do conteúdo é dedicada a aspectos econômicos, como esperado, visto o contexto nacional. Os democratas propõem o reajuste do crédito nacional, balanceado de acordo com o orçamento, assim como um equilíbrio no sistema tributário. Como foi uma crise que gerou impactos em todo o mundo, são propostas conferências internacionais objetivando a reformulação do contexto econômico: para debater a questão monetária e restaurar o comércio internacional, criando mecanismos para facilitar o câmbio (DEMOCRATIC NATIONAL CONVENTION, 1932).

Alguns princípios econômicos elucidados na plataforma são ainda de cunho ortodoxo e cíclico, como a redução dos gastos governamentais e a saída da presença do Estado em empreendimentos privados. Esses casos são exemplificados a seguir:

[...] a remoção do governo de todos os campos de empreendimento privado exceto quando necessário para o desenvolvimento de serviços públicos e recursos naturais de interesse comum.

$[\ldots]$

Defendemos uma redução imediata e drástica dos gastos governamentais, abolindo comissões inúteis e escritórios, consolidando departamentos e agências, e eliminando extravagância para realizar uma poupança de não menos de vinte e cinco por cento do custo do Governo Federal. (DEMOCRATIC NATIONAL CONVENTION, 1932, tradução elaborada pela autora)

As teorias econômicas vigentes no período consideravam a atividade econômica como cíclica, ou seja, as crises eram parte do processo do capitalismo e, dessa forma, inevitáveis. (ARTHMAR, 2002). A política aceitável pela administração pública era a de redução dos gastos, para que se aumentasse a poupança. Keynes ainda não havia publicado sua obra de mais 
relevância, A Teoria Geral do Juro, Emprego e Moeda, que saiu em 1936, não havendo, portanto, previsão de estratégias anticíclicas nos programas. Arthmar (2002, p.15) também ressalta que "nenhuma doutrina econômica do início do século XX aceitava uma política fiscal deficitária como expediente normal de ação do governo". Por isso, percebe-se a preocupação constante, não apenas em 1932, mas nas plataformas anteriores, conforme já abordado, de rigidez e redução do custo da administração.

A tentativa de retração governamental como ferramenta de combate à depressão não foi suficiente, demandando a adoção de manobras heterodoxas, que posteriormente serão realizadas. Tais propostas não se encontram presentes no programa democrata, apesar de pregarem mudanças abruptas e distintas dos republicanos, provavelmente devido à ausência de referenciais teóricos aceitados no período.

Para a propagação de novos empregos, o Partido Democrata propõe estender o crédito da União aos estados e planejar uma redução nas horas de trabalho, de modo que mais pessoas tenham acesso a postos nas empresas e indústrias. A agricultura, um dos primeiros setores a sofrer com a deflação e o desemprego, é contemplada. Os democratas defendem a necessidade de o governo garantir preços aceitáveis às commodities básicas.

A plataforma do Partido Republicano, por outro lado, é bastante extensa. Enaltece as qualidades de Hoover no tratamento do colapso econômico e aponta políticas adotadas para conter a depressão. "Nós tivemos na Casa Branca um líder - sábio, corajoso, paciente, compreensivo, inventivo, sempre presente em seu posto de dever, incansável em seus esforços e inabalavelmente fiel aos princípios e ideais americanos" (REPUBLICAN NATIONAL CONVENTION, 1932, tradução elaborada pela autora). É manifestado abertamente o apoio incondicional do partido ao presidente.

É descrito de maneira pormenorizada o programa presidencial de estímulo ao negócio e controle da situação agrícola. São apontadas medidas de concessão de empréstimo para empresas com o intuito de estimular o emprego; empréstimos para a agricultura, visando estabilizar os preços; entre outras.

O programa do Presidente contempla um ataque em uma frente ampla, com objetivos
de longo alcance, mas que não implicam em nenhum perigo para o orçamento. O
programa Democrata, por outro lado, contempla uma despesa pesada de fundos
públicos, um orçamento desequilibrado em grande escala, com uma realização
duvidosa de, no melhor dos casos, um objetivo estritamente limitado. (REPUBLICAN
NATIONAL CONVENTION, 1932, tradução elaborada pela autora)

A prioridade básica é a regulação dos orçamentos em todas as esferas públicas. Para se atingir esse objetivo, os republicanos propõem um programa de redução dos gastos 
governamentais. Reiteram também o apoio ao padrão ouro, afirmando que o momento não é propício para experimentar outros modelos. Nessa questão, emendam com a necessidade de revisão dos métodos bancários. O sistema tributário federal deve ser melhor coordenado com o local, de modo a evitar cobranças indevidas. É preciso também criar instrumentos de maior expansão de crédito, para reformular a estrutura do mercado financeiro norte-americano. (REPUBLICAN NATIONAL CONVENTION, 1932).

No tocante à questão agrícola, o programa republicano ressalta: "Na solução para este problema, as organizações cooperativas de fazendeiros para planejar a produção, e a tarifa, para assegurar o mercado doméstico para fazendeiros americanos, são elementos vitais" (REPUBLICAN NATIONAL CONVENTION, 1932, tradução elaborada pela autora). Defendem também a importância das tarifas protecionistas para a proteção dos produtos cultivados em solo norte americano. Com a Lei Tarifária de 1930, foram aumentadas as taxas agrícolas em $30 \%$, enquanto que para os produtos industriais permaneceram em $12 \%$. É preciso também, conforme apontado na plataforma, um planejamento apropriado para o sistema de crédito destinado aos fazendeiros. Ademais, propõe auxiliar no controle dos terrenos, para criar um equilíbrio na produção.

O tópico concernindo as tarifas protecionistas também está presente, assim como nas plataformas anteriores. Os republicanos permanecem na ideia de que o protecionismo é favorável, especialmente em contextos de crise. Hoover aprovou em 1930 a Tarifa HawleySmoot, com a mais alta taxa protecionista até então já aplicada nos Estados Unidos (CHESTER, 1977). O fortalecimento do produto feito nos Estados Unidos e a garantia de um mercado para absorvê-lo é uma prioridade: “O mercado doméstico, construído sob essa política, o maior e mais rico mercado do mundo, pertence primeiro a agricultura, indústria e trabalho americanos" (REPUBLICAN NATIONAL CONVENTION, 1932, tradução elaborada pela autora). Segundo o partido, a adoção desse sistema é particularmente significativa devido ao abandono do padrão ouro por diversos países - a confiabilidade do câmbio fica comprometida e, dessa forma, é ainda mais necessária a preservação do produto norte-americano.

A plataforma preza bastante por políticas realizadas, demonstrando a aptidão de Hoover para lidar com a crise e um otimismo para o futuro. No entanto, a popularidade do presidente havia decaído nos últimos anos devido à depressão. Shannon (1965, p.109, tradução elaborada pela autora) comenta: “A mais respeitada e admirada figura em 1929, o presidente Hoover em 1933 tinha se tornado um objeto de desprezo, escárnio e ódio".

A principal preocupação do Partido Republicano com a plataforma é endossar o seu status quo, de acordo com Chester (1977). As políticas adotadas de combate ao colapso 
econômico não estavam surtindo efeito; o desemprego continuava em ascensão, enquanto que a renda caía; bancos e empresas faliram; pessoas estavam sem abrigo (SHANNON, 1965). Era necessário tentar reconstruir a credibilidade e a confiança do povo norte-americano, mas esta foi uma tarefa muito difícil. A vitória democrata foi devastadora, com Franklin Delano Roosevelt como candidato. O mapa e a tabela abaixo demonstram as estatísticas eleitorais:

Imagem 10 - Resultado das Eleições de 1932

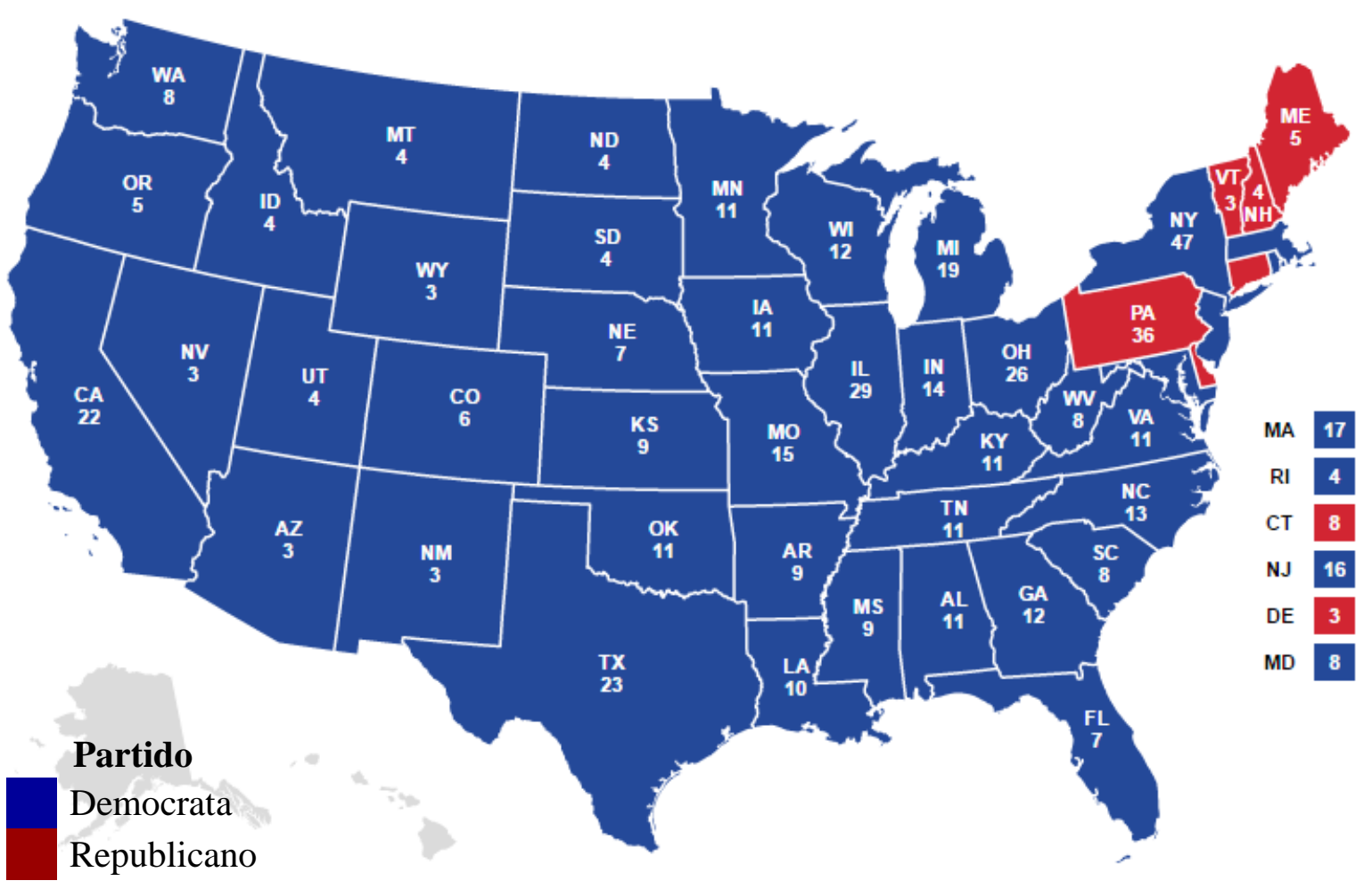

Fonte: 270 To Win (2016j). Tradução e adaptação pela autora.

Tabela 10 - Resultado das eleições de 1932

\begin{tabular}{|c|c|c|c|c|c|c|}
\hline Candidato & Vice & $\begin{array}{l}\text { Partido } \\
\text { Político }\end{array}$ & \multicolumn{2}{|c|}{ Votos populares } & \multicolumn{2}{|c|}{$\begin{array}{c}\text { Votos } \\
\text { eleitorais }\end{array}$} \\
\hline $\begin{array}{l}\text { Franklin } \\
\text { Roosevelt }\end{array}$ & John Garner & Democrata & 22.818 .740 & $57,4 \%$ & 472 & $88,9 \%$ \\
\hline Herbert Hoover & $\begin{array}{c}\text { Charles } \\
\text { Curtis }\end{array}$ & Republicano & 15.760 .425 & $39,6 \%$ & 59 & $11,1 \%$ \\
\hline \multicolumn{3}{|c|}{ Total } & 39.747 .783 & $100 \%$ & 531 & $100 \%$ \\
\hline
\end{tabular}

Fonte The American Presidency Project (2016k). Tradução e adaptação pela autora. 


\subsection{0 início da recuperação}

Franklin Roosevelt assumiu a presidência em março de 1933 e logo de início procurou fazer reformas emergenciais a fim de recuperar o nível dos preços e diminuir a taxa de desemprego. O plano de recuperação do democrata foi chamado de New Deal, compondo um conjunto de políticas de reajuste econômico. O início do governo, em 1933, foi chamado de 'os cem dias' (the hundred days), em que Roosevelt se reuniu com o Congresso e aprovou uma série de medidas (LIMONCIC; MARTINHO, 2009). A adoção de tais políticas foi possível devido a maioria democrata em ambas as Casas do Congresso Nacional. No entanto, algumas, por terem sido apressadas, foram invalidadas posteriormente pela Suprema Corte devido a inconstitucionalidade (CHESTER, 1977). O primeiro New Deal esteve em andamento entre 1933 e 1934.

Em 5 de março de 1933, em um de seus primeiros atos, Roosevelt anunciou a suspensão das transações bancárias, através do Emergency Banking Act. Tal evento ficou conhecido como ‘feriado bancário' (Bank Holiday), tinha como objetivo o reajuste do sistema e, como resultado, reestabeleceu a integridade e a confiabilidade dos bancos (SILBER, 2009). Para recuperação da agricultura, foi lançado o Agricultural Adjustment Act $(A A A)$, que tinha como objetivo incentivar a redução da produção através de subsídios governamentais, para que a oferta novamente se regulasse com a demanda e os preços voltassem a subir (LIMONCIC; MARTINHO, 2009).

Uma das primeiras medidas de recuperação do emprego foi o Civilian Conservation Corps $(C C C)$. Tal projeto consistia em efetuar serviços de recuperação de obras públicas e diminuição do nível de erosão no solo (em especial de regiões afetadas pela seca, como o estado do Oklahoma). Através desse programa, várias pessoas foram empregadas, gerando assim um aumento de renda e, consequentemente, de consumo (LIMONCIC; MARTINHO, 2009).

Foram criados também órgãos públicos responsáveis pelas reformas, sendo que o de mais relevância era a Administração da Recuperação Nacional. Buscava-se, através da centralização nessa instituição, fazer acordos entre empresários e trabalhadores para regular preços e salários. As políticas iniciais de Roosevelt mostraram resultado, mas começaram a ser insuficientes, demandando novas direções no processo de recuperação (KARNAL, 2007).

Então, em 1935 foi lançado o segundo New Deal e suas medidas se focavam mais profundamente na regulação do mercado de trabalho. Os principais instrumentos dessa fase foram o Social Security Act (SSA), de seguridade social, e o National Labor Relations Act $(N L R A)$, acerca da organização trabalhista. O primeiro objetivava garantir seguro-desemprego 
e pensões para os idosos, enquanto que o segundo visava fortalecer os sindicatos para que os trabalhadores pudessem se representar, reivindicando melhorias de salários e contratações coletivas. O propósito central dessas medidas era possibilitar o aumento do poder de compra desses segmentos e, com isso, elevar a demanda efetiva (LIMONCIC; MARTINHO, 2009).

\subsection{Plataformas partidárias de 1936}

As plataformas dos partidos Republicano e Democrata posicionam-se em dois extremos. A democrata, confiante de vitória, enaltece as políticas do New Deal de recuperação da economia, enquanto que a republicana é preenchida com acusações às medidas adotadas pela administração de Roosevelt.

O programa democrata é sucinto, mas não tão curto quanto o de 1932, e também mais organizado. Enfatiza que os anos de governo democrata foram essenciais para a recuperação da prosperidade dos Estados Unidos, algo que o governo de Hoover não tinha sido capaz de atingir. Ademais, condenam a concessão de privilégios a alguns setores implementada pelos republicanos, além da manipulação dos preços de commodities e no mercado acionário, o que teria contribuído para a eclosão da crise. Afirmam que houve sucesso na recuperação bancária, através dos planos emergenciais do presidente e, então, garantem a segurança vigente das contas correntes (DEMOCRATIC NATIONAL CONVENTION, 1936).

No tocante à questão agrícola, os democratas apontam resultado positivo das medidas adotadas com o Agricultural Adjustment Act (AAA), entre outros programas. Segundo indicado, houve redução na dívida dos trabalhadores do campo, além de restauração da fertilidade das terras. Os subsídios governamentais levantados para o ajuste da produção com a demanda foram benéficos, com os preços começando a atingir valores aceitáveis (DEMOCRATIC NATIONAL CONVENTION, 1936).

Para os trabalhadores, além de endossar os resultados advindos das políticas do New Deal, a plataforma ressalta conquistas importantes como aumento de salários e diminuição da jornada de trabalho. Com isso, mais pessoas são empregadas e aumenta-se o poder de compra geral. Os negócios, na administração democrata, melhoraram com a extensão do crédito, redução da taxa de juros básica e regulação bancária. Com essas medidas, há um amplo incentivo aos investimentos, possibilitando um aumento da movimentação econômica no país. Com esse estímulo, os democratas afirmam ter reempregado mais de 5 milhões de norteamericanos (DEMOCRATIC NATIONAL CONVENTION, 1936).

É abordada também a questão dos trustes e monopólios, com a acusação de que nos anos de administração do Partido Republicano, pouco foi feito para contê-los, inclusive registrando 
que algumas medidas adotadas contribuiriam para a sua continuidade. Sobre o tópico, os democratas ressaltam:

Comprometemo-nos vigorosamente e sem medo a fazer cumprir as disposições penais e civis das leis antitruste existentes e, na medida em que sua eficácia tenha sido enfraquecida por novos dispositivos corporativos ou construções judiciais, propomos novas leis para restaurar a eficácia na eliminação de monopólios e práticas de concentração do poder econômico. (DEMOCRATIC NATIONAL CONVENTION, 1936, tradução elaborada pela autora)

Ademais, condenam a visão republicana de canalizar a solução dos problemas a partir de ações específicas adotadas separadamente por cada estado. Afirmam, a esse respeito, que continuarão implementando políticas em âmbito federal, através da adoção de legislação em conjunto com a constituição. Chester (1977, p.204, tradução elaborada pela autora) faz uma análise desse plank:

Do ponto de vista filosófico, talvez a característica mais notável deste documento é o acoplamento depreciativa do Partido Republicano em relação aos direitos dos estados; os direitos dos estados que antes tinham sido uma parte básica da ideologia democrática, desde os dias de Jefferson. Neste contexto, a plataforma declarou que "problemas nacionais que exigem soluções imediatas" "não podem ser adequadamente tratados exclusivamente por 48 legislaturas estaduais separadas, 48 administrações estaduais separados e 48 tribunais estaduais separados", mas também afirmou que "temos procurado e continuaremos procurando satisfazer estes problemas através de legislação dentro da Constituição". A última passagem constitui uma rejeição aparente ao Supremo Tribunal por anular certas medidas do New Deal.

Dessa forma, são percebidas mudanças de abordagem do Partido Democrata. A administração ficou mais centralizada e focada no executivo, tendo o presidente essencial papel na recuperação da economia. A defesa adoção de políticas anticíclicas, com forte intervenção estatal, também se constituiu como um diferencial nessa plataforma.

O Partido Republicano, por outro lado, permanece com posições ideológicas semelhantes àquelas encontradas nas plataformas de anos anteriores. Mantém seu posicionamento de descentralização política, acusando o excesso de poder por parte do executivo no governo de Roosevelt. Os republicanos afirmam que houve perda de autonomia do Congresso Nacional e da Suprema Corte com a centralização da burocracia. São feitas, além disso, várias outras acusações de violações feitas pelo New Deal: de direitos e liberdades individuais, desrespeito à Constituição, efetuação de gastos com fins partidários (REPUBLICAN NATIONAL CONVENTION, 1936).

Salientam ainda que os programas em vigência prejudicaram a livre iniciativa, com medidas restritivas adotadas. Defendem a remoção de tais restrições de produção para que as indústrias se recuperem e o desemprego se reduza; afirmam que é necessário que haja 
incentivos, e não obstáculos aos negócios (REPUBLICAN NATIONAL CONVENTION, 1936).

São criticadas as medidas de seguridade social adotadas pelo New Deal, no sentido que são consideradas insuficientes por não contemplar boa parte da população norte-americana, segundo salientado na plataforma. Outra política reprovada pelos republicanos é o Agricultural Adjustment Act (AAA), considerado coercitivo e restritivo. Ademais, acusam a administração do New Deal de usar essa agenda em prol de interesses partidários, controlando os métodos e usos das terras. Segundo o programa republicano, um princípio básico é "facilitar a produção econômica e elevar o consumo em uma base de abundância ao invés de escassez" (REPUBLICAN NACIONAL CONVENTION, 1936, tradução elaborada pela autora). O AAA, conforme já abordado, fornece subsídios aos fazendeiros para que controlem a produção, de modo a equilibrar com a demanda existente. O Partido Republicano tem uma visão contrária, de que para recuperar os preços é necessário manter a grande oferta, que assim a demanda será gerada.

A plataforma também propõe mecanismos para melhor utilização das terras no país, através de reordenação e organização de terras abandonadas e não-produtivas. Ademais, em relação à recuperação de preços, os republicanos indicam que o melhor caminho é o protecionismo, iniciando o contexto para o plank que trata das tarifas protecionistas. Salientam o compromisso do partido em proteger os agricultores americanos contra prejuízos advindos de importações (REPUBLICAN NATIONAL CONVENTION, 1936).

Portanto, nessa questão, os republicanos permanecem na mesma linha ideológica, com a defesa vigorosa do sistema de tarifas protecionistas. Chester (1977, p.203) aponta que "provavelmente o plank mais típico encontrado neste documento era o que lidava com a tarifa protecionista". O partido afirma que intencionam revogar a Lei de Acordos Comerciais Recíprocos, por ser perigosa para a indústria e agricultura norte-americanas, podendo ter efeitos destrutivos. "Sua continuidade acarretará em dano ao assalariado e ao agricultor" (REPUBLICAN NATIONAL CONVENTION, 1936, tradução elaborada pela autora).

É rejeitada ainda a ratificação de tratados de comércio sem consulta popular ou aprovação do Congresso, sinalizando, assim, a crítica à centralização do poder. Nesse sentido, também ressaltam que é necessário retornar ao Congresso Nacional a prerrogativa de emissão de moeda, revogando leis que canalizam essa autoridade ao poder executivo. Em consonância com o programa democrata, apoiam a aplicação de leis que criminalizem a formação e manutenção de monopólios. (REPUBLICAN NATIONAL CONVENTION, 1936). 
Por fim, criticam amplamente os altos gastos empreendidos pelo governo democrata:

A Administração do New Deal tem sido caracterizada por um gasto vergonhoso, e irresponsabilidade financeira generalizada. Ela tem acumulado déficit em cima de déficit. Ela ameaça falência nacional e destruição através da inflação de apólices de seguro e depósitos bancários de poupança. (REPUBLICAN NATIONAL CONVENTION, 1936, tradução elaborada pela autora)

Apesar de todas as críticas empreendidas pelo Partido Republicano à administração de Roosevelt, os resultados das eleições foram extremamente favoráveis ao candidato democrata. A economia mostrava sinais de recuperação, o que não havia ocorrido no período de Hoover, e as pessoas em grande parte estavam satisfeitas. A diferença de votos no colégio eleitoral foi devastadora, conforme pode ser verificada no mapa e na tabela abaixo:

Imagem 11 - Resultado das eleições de 1936

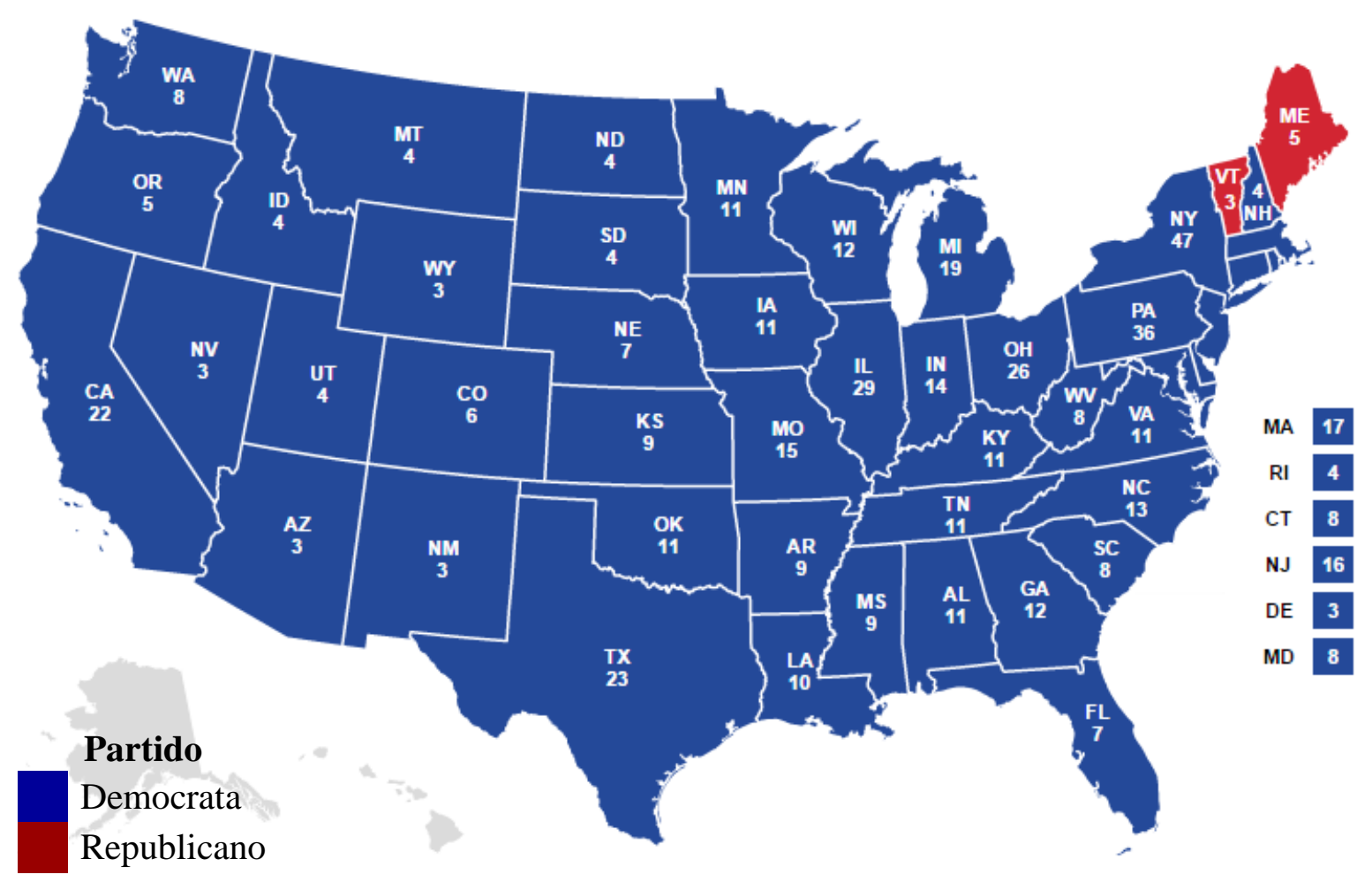

Fonte: 270 To Win (2016k). Tradução e adaptação pela autora.

Tabela 11 - Resultado das eleições de 1936

\begin{tabular}{|c|c|c|c|c|c|c|}
\hline Candidato & Vice & $\begin{array}{l}\text { Partido } \\
\text { Político }\end{array}$ & \multicolumn{2}{|c|}{ Votos populares } & \multicolumn{2}{|c|}{$\begin{array}{c}\text { Votos } \\
\text { eleitorais }\end{array}$} \\
\hline $\begin{array}{l}\text { Franklin } \\
\text { Roosevelt }\end{array}$ & John Garner & Democrata & 27.750 .866 & $60,8 \%$ & 523 & $98,5 \%$ \\
\hline Alfred Landon & Frank Knox & Republicano & 16.679 .683 & $36,5 \%$ & 8 & $1,5 \%$ \\
\hline \multicolumn{3}{|c|}{ Total } & 45.646 .991 & $100 \%$ & 531 & $100 \%$ \\
\hline
\end{tabular}

Fonte: The American Presidency Project (20161). Tradução e adaptação pela autora. 
Assim, com a reeleição de Roosevelt, percebe-se a consolidação definitiva do ciclo do New Deal, conforme proposto por Schlesinger Jr. (1992). A hegemonia republicana se encerrava com as amplas críticas recebidas pelo governo de Hoover, ao não conseguir minimizar os efeitos da depressão. Roosevelt ficará no poder até sua morte, em 1945 e pode-se considerar que essa fase gerou uma mudança de paradigmas especialmente no Partido Democrata, com mais centralidade do executivo e intervencionismo estatal. 


\section{CONSIDERAÇÕES FINAIS}

O objetivo deste trabalho era analisar as convergências e divergências entre os partidos Democrata e Republicano e como era feito o tratamento das questões econômicas no recorte temporal de 1912 a 1936. Para tal, foram utilizadas como fontes primárias as suas Plataformas Partidárias. Esses documentos foram importantes para avaliar a percepção das agremiações sobre determinados assuntos de relevo na agenda nacional.

A hipótese inicial levantada era de que com a Crise de 1929 as identidades partidárias teriam se alterado. Em parte, constata-se essa hipótese pensando sobre o Partido Democrata. De fato, quando Franklin Roosevelt assume a presidência, vários paradigmas não só do próprio partido quanto da política norte-americana no geral sofrem modificações, como o fortalecimento do poder executivo e o intervencionismo do Estado na economia.

Por outro lado, o Partido Republicano não demonstra sinais de amplas mudanças de política econômica. No governo de Herbert Hoover, após a eclosão da crise, houve aplicação de alguns mecanismos de intervenção estatal, mas de cunho apenas monetário, não gerando impactos profundos e insuficientes para minimizar os efeitos da depressão. Os republicanos perdem as eleições de 1932, mas mesmo assim o posicionamento em relação a essa questão não se altera de maneira relevante na plataforma seguinte.

O conteúdo dos programas partidários se atém a acontecimentos específicos e propostas derivadas do contexto, não havendo embates profundos em ideais. Esse fator é consonante com o que Downs (1999) disserta sobre a ideologia dos partidos. Segundo o autor, os partidos "podem simplesmente assumir posições $a d$ hoc a respeito de problemas práticos à medida que eles surgem" (DOWNS, 1999, p.119).

Cabe também refletir acerca das tomadas de decisão. Downs (1999) afirma que os agentes políticos agem racionalmente, visando a maximização de seus lucros. Nas palavras do autor:

[...] os partidos na política democrática são análogos aos empresários numa economia que busque o lucro. De modo a atingir seus fins privados, eles formulam as políticas que acreditam que lhes trarão mais votos, assim como os empresários produzem os produtos que acreditam que lhes trarão mais lucros pela mesma razão. (Downs, 1999, p.313)

Considerando esta premissa, a Crise de 1929 e os impactos por ela gerados se configuraram como um momento de oportunidade para o Partido Democrata. A primazia do Partido Republicano no poder mantinha-se ininterrupta desde 1861, com pausas pontuais de quatro mandados da agremiação oposta. Pensando-se no século XX, conforme já abordado, a 
administração de Wilson foi possível com uma margem de diferença baixa e em um momento em que os Republicanos estavam enfraquecidos. Assim, a conjunção da crise foi o momento propício para a volta ao poder, especialmente porque a administração de Hoover não foi capaz de minimizar seus efeitos.

Downs (1999) define ideologia de duas formas: como “[...] imagem verbal da boa sociedade e dos principais meios de construir tal sociedade" (DOWNS, 1999, p.118) e também como "[...] como meio para chegar ao poder" (DOWNS, 1999, p.119). Ademais, o autor também enfatiza que o desenvolvimento de ideologias distintas ocorre como mecanismo na disputa pelo poder. Dessa forma, o Partido Democrata se adapta à realidade, alterando suas políticas e programas para apresentar aos eleitores uma alternativa ao governo vigente.

O autor também disserta acerca do dilema entre a pureza ideológica e a pretensão de vitória eleitoral. Nesse tocante, pode-se considerar que os republicanos, tanto em 1932 quanto em 1936, valorizaram a continuidade de sua ideologia norteadora, uma vez que permaneceram defendendo os mesmos posicionamentos, apesar de ter falhado no controle da crise. Especialmente após a vitória democrata com Roosevelt, essa questão ficou evidente, mas a escolha do partido se conservou. O Partido Democrata, no entanto, teve maior fluidez ideológica, garantindo-se no poder. As medidas adotadas por sua administração geraram resultados positivos no combate à depressão, o que contribuiu para sua aceitação popular naquele momento.

O estudo do contexto de longo prazo das agremiações foi importante para a compreensão das dinâmicas percebidas entre 1912 e 1936. Muitos dos aspectos econômicos defendidos pelos partidos no século XIX permaneceram, sendo a divergência mais marcante entre democratas e republicanos a questão das tarifas protecionistas. Por todo o recorte temporal analisado, o Partido Republicano defendeu de forma enfática a manutenção do protecionismo, com altas taxas de importação, com o objetivo de salvaguardar o mercado doméstico. O Partido Democrata, por outro lado, valorizava a diminuição das taxas para proporcionar um mercado mais competitivo.

Sobre a presença do Estado na economia, o posicionamento de ambos os partidos era mais liberal, defendendo um afastamento do governo dos negócios e do mercado. Os democratas, na plataforma de 1932 ainda permanecem nesta crença, tendo se alterado apenas no programa de 1936. Os republicanos, no entanto, continuam repudiando o excesso de intervencionismo, como apontado na plataforma de 1936 através das críticas à administração do New Deal. Criticam também a centralidade do executivo a partir do governo de Roosevelt. 
Em relação às convergências, a que merece maior destaque é a questão dos trustes e monopólios. Em ambas as plataformas, em todo o período abarcado, é ressaltado, em maior ou menor aprofundamento, o repúdio aos abusos de monopólios. Os dois partidos defendem leis que criminalizem a prática de monopólios, trustes ou conglomerados e afirmam que essas ocorrências são extremamente prejudiciais para a competitividade dos negócios norteamericanos.

A Crise de 1929 gerou impactos de grande magnitude na sociedade não só dos Estados Unidos, como do mundo todo e, assim, alterou, apesar de não de forma muito acentuada, a estrutura das dinâmicas partidárias. Percebe-se que a crise gerou impactos na forma de pensar a política econômica do Partido Democrata, com as mudanças empreendidas por Franklin Roosevelt. No Partido Republicano, contudo, até a plataforma de 1936, não havia ocasionado grandes alterações de pensamento. A adaptação e adequação garantiu a virada democrata no poder, rompendo a predominância republicana e iniciando-se um novo ciclo político. 


\section{REFERÊNCIAS}

\section{Fontes primárias:}

\section{CONSTITUTIONAL UNION NATIONAL CONVENTION (ESTADOS UNIDOS DA} AMÉRICA). Minor/Third Party Platforms: Constitutional Union Party Platform of 1860. 1860. On-line por Gerhard Peters e John T. Woolley - The American Presidency Project. Disponível em: <http://www.presidency.ucsb.edu/ws/index.php?pid=29571>. Acesso em: 13 jul. 2016.

\section{DEMOCRATIC NATIONAL CONVENTION (ESTADOS UNIDOS DA} AMÉRICA). Democratic Party Platforms: 1856 Democratic Party Platform. 1856. On-line por Gerhard Peters e John T. Woolley - The American Presidency Project. Disponível em: <http://www.presidency.ucsb.edu/ws/index.php?pid=29576>. Acesso em: 13 jul. 2016.

Democratic Party Platforms: 1860 Democratic Party Platform. 1860. On-line por Gerhard Peters e John T. Woolley - The American Presidency Project. Disponível em: <http://www.presidency.ucsb.edu/ws/index.php?pid=29577>. Acesso em: 13 jul. 2016.

Democratic Party Platforms: 1876 Democratic Party Platform. 1876. On-line por Gerhard Peters e John T. Woolley - The American Presidency Project. Disponível em: <http://www.presidency.ucsb.edu/ws/index.php?pid=29581>. Acesso em: 13 jul. 2016.

Democratic Party Platforms: 1880 Democratic Party Platform. 1880. On-line por Gerhard Peters e John T. Woolley - The American Presidency Project. Disponível em: <http://www.presidency.ucsb.edu/ws/index.php?pid=29582>. Acesso em: 13 jul. 2016.

Democratic Party Platforms: 1884 Democratic Party Platform. 1884. On-line por Gerhard Peters e John T. Woolley - The American Presidency Project. Disponível em: <http://www.presidency.ucsb.edu/ws/index.php?pid=29583>. Acesso em: 13 jul. 2016.

Democratic Party Platforms: 1888 Democratic Party Platform. 1888. On-line por Gerhard Peters e John T. Woolley - The American Presidency Project. Disponível em: <http://www.presidency.ucsb.edu/ws/index.php?pid=29584>. Acesso em: 13 jul. 2016. 
Democratic Party Platforms: 1892 Democratic Party Platform. 1892. On-line por Gerhard Peters e John T. Woolley - The American Presidency Project. Disponível em: <http://www.presidency.ucsb.edu/ws/index.php?pid=29585>. Acesso em: 13 jul. 2016.

Democratic Party Platforms: 1896 Democratic Party Platform. 1896. On-line por Gerhard Peters e John T. Woolley - The American Presidency Project. Disponível em: <http://www.presidency.ucsb.edu/ws/index.php?pid=29586>. Acesso em: 13 jul. 2016.

Democratic Party Platforms: 1912 Democratic Party Platform. 1912. On-line por Gerhard Peters e John T. Woolley - The American Presidency Project. Disponível em: <http://www.presidency.ucsb.edu/ws/index.php?pid=29590>. Acesso em: 13 jul. 2016.

Democratic Party Platforms: 1916 Democratic Party Platform. 1916. On-line por Gerhard Peters e John T. Woolley - The American Presidency Project. Disponível em: <http://www.presidency.ucsb.edu/ws/index.php?pid=29591>. Acesso em: 13 jul. 2016.

Democratic Party Platforms: 1920 Democratic Party Platform. 1920. On-line por Gerhard Peters e John T. Woolley - The American Presidency Project. Disponível em: <http://www.presidency.ucsb.edu/ws/index.php?pid=29592>. Acesso em: 13 jul. 2016.

Democratic Party Platforms: 1924 Democratic Party Platform. 1924. On-line por Gerhard Peters e John T. Woolley - The American Presidency Project. Disponível em: <http://www.presidency.ucsb.edu/ws/index.php?pid=29593>. Acesso em: 13 jul. 2016.

Democratic Party Platforms: 1928 Democratic Party Platform. 1928. On-line por Gerhard Peters e John T. Woolley - The American Presidency Project. Disponível em: <http://www.presidency.ucsb.edu/ws/index.php?pid=29594>. Acesso em: 13 jul. 2016.

Democratic Party Platforms: 1932 Democratic Party Platform. 1932. On-line por Gerhard Peters e John T. Woolley - The American Presidency Project. Disponível em: <http://www.presidency.ucsb.edu/ws/index.php?pid=29595>. Acesso em: 13 jul. 2016.

Democratic Party Platforms: 1936 Democratic Party Platform. 1936. On-line por Gerhard Peters e John T. Woolley - The American Presidency Project. Disponível em: <http://www.presidency.ucsb.edu/ws/index.php?pid=29596>. Acesso em: 13 jul. 2016. 


\section{ESTADOS UNIDOS DA AMÉRICA. Constituição (1787) Contitution of The United}

States. Filadélfia, 1787. Disponível em

<http://www.senate.gov/civics/constitution_item/constitution.htm>. Acesso em 17 jul. 2016.

HOUSE OF REPRESENTATIVES (Estados Unidos da América). SIXTY-THIRD

CONGRESS. SEES . I. CHs. 15, 16 . 1913.1913. Disponível em:

<http://legisworks.org/sal/38/stats/STATUTE-38-Pg114.pdf〉. Acesso em: 13 jul. 2016.

PROGRESSIVE NATIONAL CONVENTION (ESTADOS UNIDOS DA

AMÉRICA). Minor/Third Party Platforms: Progressive Party Platform of 1912. 1912. Online por Gerhard Peters e John T. Woolley - The American Presidency Project. Disponível em: 〈http://www.presidency.ucsb.edu/ws/index.php?pid=29617>. Acesso em: 13 jul. 2016.

Minor/Third Party Platforms: Progressive Party Platform of 1924. 1924. On-line por Gerhard Peters e John T. Woolley - The American Presidency Project. Disponível em: <http://www.presidency.ucsb.edu/ws/index.php?pid=29618>. Acesso em: 13 jul. 2016.

\section{REPUBLICAN NATIONAL CONVENTION (Estados Unidos da América). Republican}

Party Platforms: Republican Party Platform of 1856. 1856. On-line por Gerhard Peters e John T. Woolley - The American Presidency Project. Disponível em: <http://www.presidency.ucsb.edu/ws/index.php?pid=29619>. Acesso em: 13 jul. 2016.

Republican Party Platforms: Republican Party Platform of 1860. 1860. On-line por Gerhard Peters e John T. Woolley - The American Presidency Project. Disponível em: <http://www.presidency.ucsb.edu/ws/index.php?pid=29620>. Acesso em: 13 jul. 2016.

Republican Party Platforms: Republican Party Platform of 1876. 1876. On-line por Gerhard Peters e John T. Woolley - The American Presidency Project. Disponível em: <http://www.presidency.ucsb.edu/ws/index.php?pid=29624>. Acesso em: 13 jul. 2016.

Republican Party Platforms: Republican Party Platform of 1880. 1880. On-line por Gerhard Peters e John T. Woolley - The American Presidency Project. Disponível em: <http://www.presidency.ucsb.edu/ws/index.php?pid=29625>. Acesso em: 13 jul. 2016.

Republican Party Platforms: Republican Party Platform of 1884. 1884. On-line por Gerhard Peters e John T. Woolley - The American Presidency Project. Disponível em: <http://www.presidency.ucsb.edu/ws/index.php?pid=29626>. Acesso em: 13 jul. 2016. 
Republican Party Platforms: Republican Party Platform of 1888. 1888. On-line por Gerhard Peters e John T. Woolley - The American Presidency Project. Disponível em: <http://www.presidency.ucsb.edu/ws/index.php?pid=29627>. Acesso em: 13 jul. 2016.

Republican Party Platforms: Republican Party Platform of 1892. 1892. On-line por Gerhard Peters e John T. Woolley - The American Presidency Project. Disponível em: <http://www.presidency.ucsb.edu/ws/index.php?pid=29628>. Acesso em: 13 jul. 2016.

Republican Party Platforms: Republican Party Platform of 1896. 1896. On-line por Gerhard Peters e John T. Woolley - The American Presidency Project. Disponível em: <http://www.presidency.ucsb.edu/ws/index.php?pid=29629>. Acesso em: 13 jul. 2016.

Republican Party Platforms: Republican Party Platform of 1912. 1912. On-line por Gerhard Peters e John T. Woolley - The American Presidency Project. Disponível em: <http://www.presidency.ucsb.edu/ws/index.php?pid=29633>. Acesso em: 13 jul. 2016.

Republican Party Platforms: Republican Party Platform of 1916. 1916. On-line por Gerhard Peters e John T. Woolley - The American Presidency Project. Disponível em: <http://www.presidency.ucsb.edu/ws/index.php?pid=29634>. Acesso em: 13 jul. 2016.

Republican Party Platforms: Republican Party Platform of 1920. 1920. On-line por Gerhard Peters e John T. Woolley - The American Presidency Project. Disponível em: <http://www.presidency.ucsb.edu/ws/index.php?pid=29635>. Acesso em: 13 jul. 2016.

Republican Party Platforms: Republican Party Platform of 1924. 1924. On-line por Gerhard Peters e John T. Woolley - The American Presidency Project. Disponível em: <http://www.presidency.ucsb.edu/ws/index.php?pid=29636>. Acesso em: 13 jul. 2016.

Republican Party Platforms: Republican Party Platform of 1928. 1928. On-line por Gerhard Peters e John T. Woolley - The American Presidency Project. Disponível em: <http://www.presidency.ucsb.edu/ws/index.php?pid=29637>. Acesso em: 13 jul. 2016.

Republican Party Platforms: Republican Party Platform of 1932. 1932. On-line por Gerhard Peters e John T. Woolley - The American Presidency Project. Disponível em: <http://www.presidency.ucsb.edu/ws/index.php?pid=29638>. Acesso em: 13 jul. 2016. 
Republican Party Platforms: Republican Party Platform of 1936. 1936. On-line por

Gerhard Peters e John T. Woolley - The American Presidency Project. Disponível em: <http://www.presidency.ucsb.edu/ws/index.php?pid=29639>. Acesso em: 13 jul. 2016.

Republican Party Platforms: Republican Party Platform of 1936. 1936. On-line por

Gerhard Peters e John T. Woolley - The American Presidency Project. Disponível em: <http://www.presidency.ucsb.edu/ws/index.php?pid=29639>. Acesso em: 13 jul. 2016.

\section{SOUTHERN DEMOCRATIC NATIONAL CONVENTION (ESTADOS UNIDOS DA} AMÉRICA). Minor/Third Party Platforms: Democratic Party Platform (Breckinridge Faction) of 1860. 1860. On-line por Gerhard Peters e John T. Woolley - The American Presidency Project. Disponível em: <http://www.presidency.ucsb.edu/ws/index.php?pid=29617>. Acesso em: 13 jul. 2016.

THE AMERICAN PRESIDENCY PROJECT. Election of 1848. 2016a. Disponível em: <http://www.presidency.ucsb.edu/showelection.php?year=1848>. Acesso em: 13 jul. 2016.

Election of 1852. 2016b. Disponível em:

<http://www.presidency.ucsb.edu/showelection.php?year=1852>. Acesso em: 13 jul. 2016.

Election of 1856. 2016c. Disponível em:

<http://www.presidency.ucsb.edu/showelection.php?year=1856>. Acesso em: 13 jul. 2016.

Election of 1860. 2016d. Disponível em:

<http://www.presidency.ucsb.edu/showelection.php?year=1860>. Acesso em: 13 jul. 2016.

Election of 1876. 2016e. Disponível em:

<http://www.presidency.ucsb.edu/showelection.php?year=1876>. Acesso em: 13 jul. 2016.

Election of 1912. 2016f. Disponível em:

<http://www.presidency.ucsb.edu/showelection.php?year=1912>. Acesso em: 13 jul. 2016.

Election of 1916. 2016g. Disponível em:

<http://www.presidency.ucsb.edu/showelection.php?year=1916>. Acesso em: 13 jul. 2016.

Election of 1920. 2016h. Disponível em:

<http://www.presidency.ucsb.edu/showelection.php?year=1920>. Acesso em: 13 jul. 2016. 
Election of 1924. 2016i. Disponível em:

<http://www.presidency.ucsb.edu/showelection.php?year=1924>. Acesso em: 13 jul. 2016.

Election of 1928. 2016j. Disponível em:

<http://www.presidency.ucsb.edu/showelection.php?year=1928>. Acesso em: 13 jul. 2016.

Election of 1932. 2016k. Disponível em:

<http://www.presidency.ucsb.edu/showelection.php?year=1932>. Acesso em: 13 jul. 2016.

Election of 1936. 20161. Disponível em:

<http://www.presidency.ucsb.edu/showelection.php?year=1936>. Acesso em: 13 jul. 2016.

THE NEW YORK TIMES. Taft 566 - Roosevelt 466: Present Line-up of Instructed and Pledged Delegates with all the Contests Decided. 1912. Disponível em:

$<$ http://query.nytimes.com/mem/archive-

free/pdf?res=9404E5D91E3CE633A25755C1A9609C946396D6CF>. Acesso em: 13 jul. 2016.

270 TO WIN. 1852 Presidential Election. 2016a. Disponível em:

<http://www.270towin.com/1852_Election/>. Acesso em: 13 jul. 2016.

1856 Presidential Election. 2016b. Disponível em:

<http://www.270towin.com/1856_Election/>. Acesso em: 13 jul. 2016.

1860 Presidential Election. 2016c. Disponível em:

<http://www.270towin.com/1860_Election/>. Acesso em: 13 jul. 2016.

1876 Presidential Election. 2016d. Disponível em:

<http://www.270towin.com/1876_Election/>. Acesso em: 13 jul. 2016.

1912 Presidential Election. 2016e. Disponível em:

<http://www.270towin.com/1912_Election/>. Acesso em: 13 jul. 2016.

1916 Presidential Election. 2016f. Disponível em:

<http://www.270towin.com/1916_Election/>. Acesso em: 13 jul. 2016.

1920 Presidential Election. 2016g. Disponível em:

<http://www.270towin.com/1920_Election/>. Acesso em: 13 jul. 2016. 
1924 Presidential Election. 2016h. Disponível em:

<http://www.270towin.com/1924_Election/>. Acesso em: 13 jul. 2016.

1928 Presidential Election. 2016i. Disponível em:

<http://www.270towin.com/1928_Election/>. Acesso em: 13 jul. 2016.

. 1932 Presidential Election. 2016j. Disponível em:

<http://www.270towin.com/1932_Election/>. Acesso em: 13 jul. 2016.

1936 Presidential Election. 2016k. Disponível em:

<http://www.270towin.com/1936_Election/>. Acesso em: 13 jul. 2016. 


\section{Fontes secundárias:}

ARRIGHI, Giovanni. O longo século XX: dinheiro, poder e as origens de nosso tempo. 5. ed. Rio de Janeiro: Contraponto, 2012.

ARTHMAR, Rogério. Os Estados Unidos e a economia mundial no Pós-Primeira Guerra. Revista Estudos Históricos, Rio de Janeiro, v. 1, n. 29, p. 97-117, out. 2002. ISSN 21781494. Disponível em: 〈http://bibliotecadigital.fgv.br/ojs/index.php/reh/article/view/2156>. Acesso em: 18 Jul. 2016.

BAILEY, Thomas Andrew. Democrats vs. Republicans: The continuing clash. New York: Meredith Press, 1968.

BERSTEIN, Serge. Os Partidos. In: RÉMOND, René. Por uma história política. Rio de Janeiro: Editora FGV, 2003.

BINKLEY, Wilfred E. Partidos Políticos Americanos - Sua história natural. Rio de Janeiro: Editora Fundo de Cultura S. A., 1961.

BOBBIO, Norberto. Estado, governo e sociedade: por uma teoria geral da política. Rio de Janeiro: Paz e Terra, 1987.

Dicionário de Política. Brasília: Editora Universidade de Brasília, 1998.

BOURDIEU, Pierre. Curso 17.01.1991; Curso 07.02.1991; Curso 14.03.1991; Curso

28.11.1991. In: Sobre o Estado: cursos no Collège de France (1989-92). São Paulo:

Companhia das Letras, 2014.

BRAUDEL, Fernand. Escritos sobre história. São Paulo: Perspectiva, 1969.

Dinâmica do capitalismo. Rio de Janeiro: Rocco, 1987.

CANDEIAS, Mario. Organic crisis and capitalist transformation. World Review of Political Economy, Shanghai, v. 2, n. 1, 2011. Disponível em:

<http://www.jstor.org/stable/41931917>. Acesso em: 16 jul. 2015.

CHESTER, Edward W.. A Guide to Political Platforms. Hamden: Archon Book, 1977. 
COGGIOLA, Osvaldo L. A.. Capitalismo: "Globalização" e Crise. São Paulo: Humanitas, 1998. v. 1.

COLE, Harold L.; OHANIAN, Lee E. New Deal Policies and the Persistence of the Great Depression: A General Equilibrium Analysis. The Journal of Political Economy, Chicago, v. 112, n. 4, 2004. Disponível em: <http://www.jstor.org/stable/3555138>. Acesso em: 02 ago. 2010 .

COMMAGER, Henry Steele. The American Political Party. The American Scholar, Washington, D.C., Vol. 19, No. 3, p. 309-316, 1950. Disponível em: <http://www.jstor.org/stable/41205319>. Acesso em: 15 mar. 2016.

DOWNS, Anthony. Uma Teoria econômica da democracia. São Paulo: Edusp, 1999.

DUROSELLE, Jean Baptiste. Todo império perecerá: Teoria das Relações Internacionais. Brasília: Editora Universidade de Brasília, 2000.

DUVERGER, Maurice. Os partidos políticos. Brasília: Editora Universidade de Brasília, 1980.

FOUNDING FATHERS Federalist Papers. Disponível em:

<www.foundingfathers.info/federalistpapers>. Acesso em: 30 mar. 2016.

FREIDEL, Frank Burt. Franklin D. Roosevelt. Boston: Little Brown, 1952. 3 v.

FUSFELD, Daniel Roland. The economic thought of Franklin D. Roosevelt and the origins of the New Deal. New York: Columbia Univ. Press, 1956.

GALBRAITH, John Kenneth. 1929, o colapso da bolsa. São Paulo: Pioneira, 1988.

GAZIER, Bernard. A Crise de 1929. Porto Alegre: L\&PM Editores, 2009.

HOBSBAWM, E. J. Era dos extremos: o breve século XX: 1914-1991. 2. ed. São Paulo: Companhia das Letras, 1995.

HOOVER, Herbert Clark. Memoirs. New York: Macmillan, 1951. 3 v.

The New Day: Campaign Speeches of Herbert Hoover 1928. Whitefish: Kessinger Publishing, LLC, 2010. 
HUBERMAN, Leo. Nós, o povo: A epopeia norte-americana. São Paulo: Brasiliense, 1966. História da riqueza do homem. 22. ed. Rio de Janeiro: LTC, 2010.

IZECKSOHN, Vitor. Escravidão, federalismo e democracia: a luta pelo controle do Estado nacional norte-americano antes da Secessão. Topoi, Rio de Janeiro, Vol. 6, p. 47-81, 2003. Disponível em: 〈http://www.revistatopoi.org/numeros_anteriores/Topoi06/topoi6a2.pdf〉. Acesso em: 19 jan. 2015.

JOHNSON, Paul. A History of the American People. Nova Iorque: Harpercollins Publishers, Inc., 1997.

KALB, Deborah (Ed.). Guide to U.S. Elections. 7. ed. Thousand Oaks: Cq Press, 2016.

KARNAL, Leandro. História dos Estados Unidos: das origens ao século XXI. São Paulo: Contexto, 2007.

KEYNES, John Maynard. Teoria geral do emprego, do juro e da moeda. São Paulo: Saraiva, 2012.

KINDLEBERGER, Charles Poor. Economia internacional. 7. ed. Madrid: Aguilar, 1982. The World in Depression, 1929-1939. Berkeley; Los Angeles: University of California Press, 1986.

Manias, pânico e crashes: Um histórico das crises financeiras. Rio de janeiro: Nova Fronteira, 2000.

KISSINGER, Henry. Diplomacia. São Paulo: Saraiva, 2012.

KOSELLECK, Reinhart. Crisis. Journal of the History of Ideas, Pennsylvania, Vol. 67, No. 2, p. 357-400, 2006. Disponível em: <http://www.jstor.org/stable/30141882>. Acesso em: 03 abr. 2014.

LAWSON, Kay. Political Parties and Democracy in the United States. Nova Iorque: Charles Scribner's Sons, 1968. 
LIMONCIC, Flavio; MARTINHO, Francisco Carlos Palomanes (Org). A Grande Depressão

- Política e economia na década de 1930 - Europa, Américas, África e Ásia. Rio de Janeiro: Civilização Brasileira, 2009.

LINK, Arthur Stanley; CATTON, William B. História moderna dos Estados Unidos. Rio de Janeiro: Zahar, 1965. $3 \mathrm{v}$.

MAGDOFF, Harry; SWEEZY, Paul Marlor. Crise do capitalismo americano. Rio de Janeiro: Zahar, 1982.

MILTON, Derber. Labor and the new deal. Madison: Univ. Wisconsin, 1961.

MICHELS, Robert. Sociologia dos partidos políticos. Brasília: Editora Universidade de Brasília, 1982.

MILKIS, Sidney M.. The Transformation of American Democracy: Teddy Roosevelt, the 1912 Election, and the Progressive Party. First Principles: Foundational Concepts to

Guide Politics and Policy. Washington, p. 1-12. Jun. 2012. Disponível em:

<http://www.heritage.org/research/reports/2012/06/the-transformation-of-americandemocracy-teddy-roosevelt-the-1912-election-and-the-progressive-party>. Acesso em: 13 jul. 2016.

NOGUEIRA, João Pontes; MESSARI, Nizar. Teoria das Relações Internacionais:

Correntes e Debates. Rio de Janeiro: Elsevier, 2005.

PANEBIANCO, Angelo. Modelos de partido: organização e poder nos partidos políticos.

São Paulo: Martins Fontes, 2005.

PARKER, Selwyn. O Crash de 1929: as lições que ficaram da Grande Depressão. São Paulo: Globo, 2009.

POLIANSKI, F. Y.; SHEMISKINE, I. N. História econômica dos Estados Unidos. Lisboa: Estampa, 1973.

RANNEY, Austin; WILLMORE, Kendall. Democracy and the American Party System. New York: Harcourt, Brace and Company, 1956.

REIS FILHO, Daniel Aarão. Século XX. Rio de Janeiro: Civilização Brasileira, 2000. 3 v. 
RÉMOND, René. Século XX: De 1914 aos nossos dias. São Paulo: Cultrix, 1974. (Org.). Por uma história política. Rio de Janeiro: Editora FGV, 2003.

ROWLING, J. K. Harry Potter and the Deathly Hallows. London: Bloomsbury, 2007.

SABADINI, Mauricio de Souza. Especulação financeira e capitalismo contemporâneo: uma proposição teórica a partir de Marx. Econ. soc., Campinas, v. 22, n. 3, p. 583-608, Dec. 2013. Disponível em: <http://www.scielo.br/scielo.php?script=sci_arttext\&pid=S010406182013000300001\&lng=en\&nrm=iso>. Acesso em: 18 jul. 2016. http://dx.doi.org/10.1590/S0104-06182013000300001.

SARTORI, Giovanni. Partidos e sistemas partidários. Brasília: Editora Universidade de Brasília, 1982.

SCHLESINGER, Arthur Meier. History of U.S. political parties. New York: Chelsea House Publishers, 1980. 4 v.

SCHLESINGER JR., Arthur Meier. Os Ciclos da História Americana. Rio de Janeiro: Civilização Brasileira, 1992.

SHANNON, David A.. Between the Wars: America, 1919-1941. Boston: Houghton Mifflin Company, 1965. $259 \mathrm{p}$.

SILBER, William L.. Why Did FDR's Bank Holiday Succeed? Frbny Economic Policy Review. Nova Iorque, p. 19-30. jul. 2009. Disponível em:

<https://www.newyorkfed.org/medialibrary/media/research/epr/09v15n1/0907silb.pdf>. Acesso em: 13 jul. 2016.

SORAUF, Frank J.. Party Politics in America. Boston: Little, Brown And Company, Inc., 1968.

TOTA, Antonio Pedro. Origens do bipartidarismo: uma tentativa de entender as eleições norte-americanas. Novos estud. - CEBRAP, São Paulo, No. 81, p. 69-76, jul. 2008. Disponível em: <http://www.scielo.br/scielo.php?script=sci_arttext\&pid=S0101$33002008000200007 \& \operatorname{lng}=\mathrm{en} \& \mathrm{nrm}=\mathrm{iso}>$. Acesso em: 03 abr. 2016.

Os Americanos. São Paulo: Contexto, 2009. 
WALETT, Francis G.. Economic History of the United States. Nova Iorque: Barnes \& Noble, Inc., 1954. (College Outline Series).

WEBER, Max. Ciência e política, duas vocações. São Paulo: Cultrix, 2000.

WELLS, 0. V.. The Depression of 1873-79. Journal of Farm Economics. Chicago, p. 621633. maio 1937. Disponível em: 〈http://www.jstor.org/stable/1230975>. Acesso em: 26 jun. 2016. 